\title{
ANDREA KEIKO FUJINAMI GUSHKEN
}

Adaptação do teste de provocação oral duplo cego placebo controlado para o diagnóstico de alergia às proteínas do leite de vaca mediada pela imunoglobulina $E$, na faixa etária pediátrica

\author{
Dissertação apresentada à Faculdade de \\ Medicina da Universidade de São Paulo para \\ obtenção do título de Mestre em Ciências
}

Área de Concentração: Pediatria

Orientadora: Dra. Cristina Miuki Abe Jacob

SÃO PAULO 
Devemos ser o espelho da mudança que estamos propondo.

Se eu quero mudar o mundo, tenho que começar por mim.

Mahatma Gandhi 


\section{DEDICATÓRIA}

Ao meu querido marido Roberto, pela compreensão e companheirismo, frutos da maturidade de um grande amor

Às queridas filhas Fernanda e Ana Paula, que dão um significado especial à minha vida 


\section{DEDICATÓRIA}

Aos meus queridos pais, Takashi e Milco, exemplos de amor e dedicação à educação dos filhos, a quem devo minha formação e eterna gratidão 


\section{AGRADECIMENTOS}

À querida Dra. Cristina, idealizadora e orientadora deste trabalho, que me concedeu tantas oportunidades e a quem serei eternamente grata por todos os ensinamentos.

Ao querido Dr Pastorino, a quem admiro muito, obrigada pelo apoio ao longo destes anos todos.

À querida amiga Dra. Ana Paula M.B. Castro, exemplo de dedicação à ciência e ao ensino, que muito contribuiu desde o início deste trabalho. Obrigada pelo incentivo e apoio.

À Dra Ângela, pelas valiosas sugestões.

Agradeço às nutricionistas e queridas amigas Glauce Yonamine e Gabriela Ackel Corradi pela preciosa colaboração durante a realização de todas as etapas deste trabalho.

Ao Prof. Ulysses, pelo importante auxílio durante a análise dos dados.

Às médicas e queridas amigas do Ambulatório de Alergia Alimentar: Ana Cláudia e Cleonir, pela amizade, apoio e torcida.

Ao meu querido grupo da Unidade de Alergia e Imunologia, pela cooperação e incentivo à realização deste trabalho. 


\section{AGRADECIMENTOS}

À querida amiga Denise Kanarek, companheira durante os meus primeiros anos neste serviço e grande incentivadora durante estes anos todos.

À equipe multiprofissional do Hospital Dia, pelo apoio e incentivo.

À Dra Cristina Kokron e ao Carlos R. O. Palma pela gentileza de realizar as pesquisas de lgE específica séricas.

À Mariza K. U. Yoshikawa, pela contribuição na revisão bibliográfica e pela amizade construída ao longo destes anos

Às secretárias do Departamento de Pediatria e do Instituto da Criança, em especial à Adriana Bezerra e Solange Serôdio, pela disponibilidade e apoio

À Milena e Nivaldo, pelo apoio e pela torcida

À CAPES, pela bolsa de pesquisa concedida para a realização deste estudo 



\section{AGRADECIMENTOS ESPECIAIS}

À Deus, por me guiar e abençoar.

Aos meus queridos irmãos Adriana, Henry, Alexandra e Heitor, pelo amor e respeito que nos unem.

Aos meus queridos sogros Hatsuka e Cotoku Gushken, pelo carinho e exemplo de determinação.

Aos queridos cunhados e cunhadas, por fazerem parte desta "grande família".

Aos meus sobrinhos amados, pela alegria.

Às secretárias Cristina, Cida, Michele, Ana, Tainan e Monike, pela paciência e compreensão.

À Benedita Eugênio e Lurdes Eugênio, pelo apoio e dedicação.

À Vitória Ribeiro, pelo incentivo no início desta caminhada.

Aos pacientes e seus familiares pela confiança e disponibilidade na participação do estudo. 
Esta tese está de acordo com as seguintes normas, em vigor no momento desta publicação:

Referências: adaptado de International Committee of Medical Journals Editors (Vancouver)

Universidade de São Paulo. Faculdade de Medicina. Serviço de Biblioteca e Documentação. Guia de apresentação de dissertações, teses e monografias. Elaborado por Anneliese Carneiro da Cunha, Maria Júlia de A.L. Freddi, Maria F. Crestana, Marinalva de Souza Aragão, Suely Campos Cardoso, Valéria Vilhena. $2^{\underline{a}}$ de. São Paulo: Serviço de Biblioteca e Documentação; 2005.

Abreviaturas dos títulos dos periódicos de acordo com List of Journals Indexed in Index Medicus 


\section{SUMÁRIO}

Lista de abreviaturas e siglas

Lista de gráficos

Lista de tabelas

Resumo

Summary

I.INTRODUÇÃO.

Fatores de risco para o desenvolvimento de alergia alimentar........ 6

Fisiopatologia da alergia alimentar........................................... 7

Manifestações clínicas da alergia alimentar lgE mediada............... 9

Abordagem diagnóstica.......................................................... 11

Exames laboratoriais........................................................... 12

Tratamento e História natural da alergia alimentar....................... 21

II.OBJETIVOS .................................................................... 24

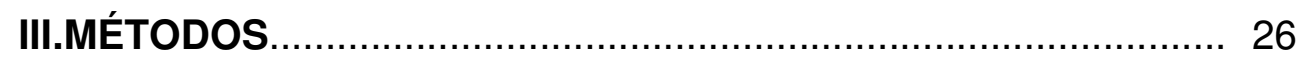

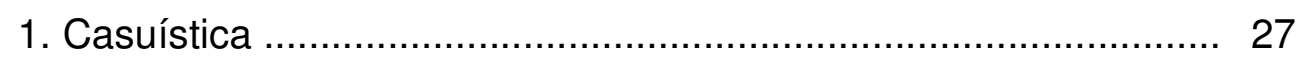

1.1 Critérios de inclusão.......................................................... 27

1.2 Critérios de exclusão....................................................... 28

1.3 Constituição final da casuística............................................ 29

1.4 Descrição dos dados demográficos e antecedentes de atopia 29 dos pacientes incluídos no estudo.

2 Metodologia.................................................................... 30

2.1 Fase experimental...................................................... 31

2.1.1 Idealização do TPODCPC adaptado.................................. 31

2.1.2 A escolha do local para a realização do TPODCPC............. 31 
2.1.3 Profissionais envolvidos diretamente na realização do TPODCPC

2.1.4 Materiais necessários para a realização do TPODCPC. 32

2.1.5 Equipamentos e materiais necessários para o preparo das porções do teste. 33

2.1.6 Materiais necessários para a realização do exame. 33

2.1.7 Tempo necessário para o preparo das porções do teste. 34

2.1.8 A escolha dos veículos. 34

2.1.9 Esquema para a administração do TPODCPC. 37

2.1.10 Orientações Pré-teste. 38

2.1.11 Avaliação Clínica. 41

2.1.12 Avaliação Laboratorial. 41

2.2 Fase de execução dos testes. 43

2.2.1 Randomização das fase. 43

2.2.2 Intervalo após a $1^{\underline{a}}$ fase cega. 44

2.2.3 Interpretação do exame. 44

2.2.4 Fase aberta. 45

2.2.5 Orientação pós teste 46

2.3 Descrição dos dados obtidos no desenvolvimento do TPODCPC adaptado. 47

2.3.1 Análise estatística............................................................... 47

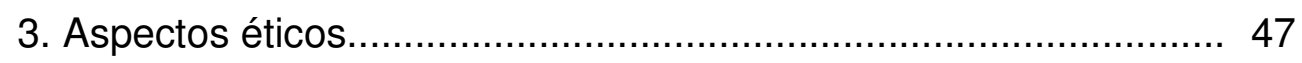

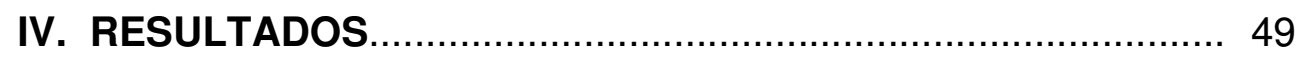

1. Resultados da fase experimental........................................... 50

1.1 A escolha do local para a realização do exame........................ 50

$1.2 \mathrm{~A}$ escolha dos veículos...................................................... 52

1.3 Materiais necessários para a realização do TPODCPC.............. 56

1.3.1 A escolha dos recipientes...................................................... 56 
1.3.2 A escolha da forma de apresentação do leite de vaca para o teste 57

1.4 Adaptações no esquema de administração do teste. 58

2. Dados relacionados à execução do teste. 59

2.1 Dificuldades. 59

3 Análise descritiva da associação entre antecedentes de atopia e exames laboratoriais em relação aos resultados do TPODCPC...... 64

V. DISCUSSÃO ............................................................... 74

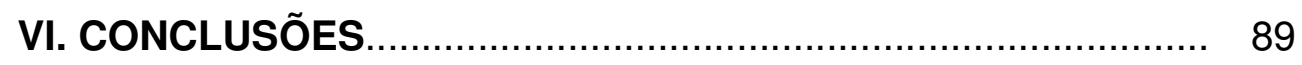

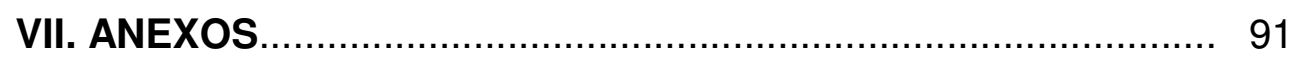

VIII. REFERÊNCIAS BIBLIOGRÁFICAS ................................. 99 


\section{LISTA DE ABREVIATURAS E SIGLAS}

AA

APLV

APT

CAPPesq

DRGE

ELISA

HC FMUSP

$\lg E$

LV

Prick test

RAST

SAO

TGI

TPO

TPODCPC

$\alpha$

$\beta$

(B)

- Alergia Alimentar

- Alergia às Proteínas do Leite de Vaca

- "Atopic patch test"

- Comissão de Ética para Análise de Projetos de Pesquisa

- Doença do Refluxo Gastro-esofágico

- Enzyme-Linked-Immunosorbent Assay

- Hospital das Clínicas da Faculdade de Medicina da Universidade de São Paulo

- Imunoglobulina E

- Leite de vaca

-Teste de puntura de leitura imediata

- Radioimmunoallergosorbent Test

- Síndrome da Alergia Oral

- Trato gastrintestinal

- Teste de Provocação Oral

- Teste de Provocação Oral Duplo Cego Placebo

Controlado

- Alfa

- Beta

- marca registrada

\section{Unidades de Referência}

$\begin{array}{ll}\mathrm{g} & \text { - grama } \\ \mathrm{kg} & \text { - kilo } \\ \mathrm{kDa} & \text { - kilo dalton } \\ \mathrm{kU} / \mathrm{L} & \text { - kilo unidades por litro } \\ \mathrm{mg} & \text { - miligrama } \\ \mathrm{mg} / \mathrm{mL} & \text { - miligrama por mililitro } \\ \mu \mathrm{g} / \mathrm{mL} & \text { - micrograma por mililitro } \\ \mathrm{mL} & \text { - mililitro } \\ \mathrm{mm} & \text { - milímetro } \\ \mathrm{mm} & \text { - milímetro cúbico } \\ \mu \mathrm{L} & \text { - microlitro } \\ \mathrm{TH} 1 & \text { - células T helper } 1 \\ \mathrm{TH} 2 & \text { - células T helper } 2 \\ \mathrm{IL} 10 & \text { - Interleucina } 10\end{array}$




\section{LISTA DE TABELAS}

Tabela 1-Descrição dos dados demográficos e presença de atopia familiar e pessoal dos 58 pacientes dos grupos 1 e 2 que realizaram 0 Teste de Provocação Oral Duplo Cego Placebo Controlado. .29

Tabela 2-Descrição dos dados laboratoriais de 58 pacientes dos grupos 1 e 2 submetidos ao Teste de Provocação Oral Duplo Cego Placebo Controlado 30

Tabela 3-Veículos utilizados pelos pacientes durante o TPODCPC............36

Tabela 4-Administração de LV ou placebo (conforme randomização).........44

Tabela 5-Aceitação dos veículos utilizados pelos pacientes......................55

Tabela 6-Esquema de administração de LV ou placebo modificado de WILLIAMS \& BOCK, 1999. .58

Tabela 7-Manifestações clínicas imediatas durante a realização do TPODCPC em 39 pacientes do Grupo1 61

Tabela 8-Descrição das reações tardias em cinco pacientes do grupo 1 ....62

Tabela 9-Reações na fase placebo dos 44 pacientes submetidos ao TPODCPC e que realizaram pelo menos duas fases do teste......62

Tabelas 10-Freqüência de Atopia Familiar e Atopia Pessoal e sua associação com os resultados do TPODCPC. .65

Tabela 11-Comparação das medianas dos dados laboratoriais com os resultados do TPODCPC. .65 


\section{LISTA DE FIGURAS}

Figura 1-Foto da enfermaria do Hospital Dia do Instituto da Criança do HCFMUSP. .51

Figura 2-Foto da copa do Hospital Dia do Instituto da Criança do HCMFUSP. .52

Figura 3-Foto das porções com Tonyu ${ }^{\circledR}$ de morango e maracujá (com placebo e LV)... .54

Figura 4-Foto dos recipientes utilizados no TPODCPC. .57

\section{LISTA DE QUADROS}

Quadro 1-Adaptação realizada para o TPODCPC em relação às referências de literatura. .38

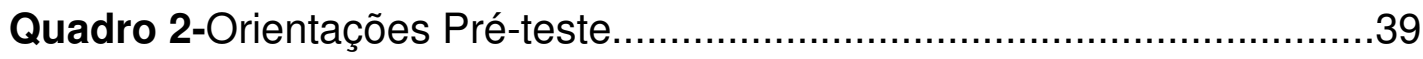

Quadro 3-Orientações Pré-teste: Modificações no Check list. 40 


\section{LISTA DE GRÁFICOS}

Gráfico 1- Distribuição das concentrações séricas de lgE específica para leite de vaca nos grupos com TPODCPC negativo e positivo.

Gráfico 2- Distribuição das concentrações séricas de lgE específica para a-lactoalbumina nos grupos com TPODCPC negativo e positivo

Gráfico 3- Distribuição das concentrações séricas de IgE específica para $\beta$-lactoglobulina nos grupos com TPODCPC negativo e positivo

Gráfico 4- Distribuição das concentrações séricas de IgE específica para Caseína nos grupos com TPODCPC negativo e positivo........69

Gráfico 5- Distribuição das medidas da pápula do Prick Test para leite de vaca nos grupos com TPODCPC negativo e positivo .70

Gráfico 6- Distribuição das medidas da pápula do Prick Test para $\beta$-lactoglobulina nos grupos com TPODCPC negativo e positivo

Gráfico 7- Distribuição das medidas da pápula do Prick Test para Caseína nos grupos com TPODCPC negativo e positivo........72

Gráfico 8- Distribuição das medidas da pápula do Prick Test para $L V$ in natura nos grupos com TPODCPC negativo e positivo. 


\section{RESUMO}

Gushken AKF. Adaptação do Teste de Provocação Oral Duplo Cego Placebo Controlado para o diagnóstico de Alergia às Proteínas do Leite de Vaca mediada pela Imunoglobulina E, na faixa etária pediátrica (Dissertação). São Paulo: Faculdade de Medicina da Universidade de São Paulo; 2009.

O Teste de Provocação Oral Duplo Cego Placebo Controlado (TPODCPC) é considerado um método diagnóstico de extrema importância na alergia alimentar, entretanto não existe, em nosso meio, uma padronização em relação aos materiais e métodos para a sua execução, especialmente na faixa etária pediátrica. $\mathrm{O}$ objetivo deste estudo foi adaptar TPODCPC para o diagnóstico de alergia às proteínas do leite de vaca (APLV) mediada por lgE, em crianças e adolescentes. O objetivo secundário foi descrever a relação entre os antecedentes de atopia associados a dados laboratoriais e os resultados dos TPODCPC. Foram incluídos 58 pacientes que se dividiram em dois grupos. O grupo 1 foi composto por 39 pacientes (mediana de idade: 5,3 anos; 1,6M:1F) com história sugestiva de APLV IgE mediada, sem relato de história de anafilaxia recente e com pesquisa positiva de $\lg E$ específica para leite de vaca (LV) e/ou frações. No grupo 2 foram incluídos 19 pacientes (mediana de idade: 8,3 anos; 1,4 M:1F) sem história sugestiva de APLV. Os itens avaliados na adaptação deste método diagnóstico 
incluíram: escolha do local, materiais a serem utilizados e operacionalização do teste. O hospital dia mostrou-se, por suas características, adequado à realização do exame. Em relação aos materiais escolhidos para a oferta do veículo, os recipientes opacos e vedados revelaram-se mais adaptados às necessidades do teste, os veículos de maior aceitação foram sopa de legumes e bebida à base de soja e o LV a ser oferecido de maneira mais apropriada foi na forma líquida e com baixo teor de lactose. As dificuldades observadas na realização do TPODCPC não comprometeram a sua execução, entretanto houve dificuldade na interpretação dos resultados especialmente nos pacientes com sintomas como pápulas periorais ou achados clínicos inespecíficos. Observou-se concordância entre os critérios clínico-laboratoriais adotados para a definição dos grupos 1 e 2 com os resultados do TPODCPC. Em conclusão, o teste mostrou-se exeqüível e seguro e a adaptação deste para o diagnóstico de APLV IgE mediada nesta faixa etária pediátrica foi possível, sendo necessária a avaliação da sua reprodutibilidade em outras populações.

Descritores: Hipersensibilidade alimentar/ diagnóstico, Leite de vaca, Metodologia, Criança, Adolescente 


\section{SUMMARY}

Gushken AKF. Adaptation of the Double Blind Placebo Controlled Oral Food Challenge for the Cow's Milk Allergy diagnosis mediated by Immunoglobulin E, in pediatric age (dissertation). São Paulo: Faculdade de Medicina da Universidade de São Paulo; 2009.

The Double Blind Placebo Controlled Food Challenge (DBPCFC) is considered an important method for food allergy diagnosis, nevertheless it is not standardized among us. The aim of this study was to adapt DBPCFC for cow's milk allergy (CMA) diagnosis in children and adolescents. A secondary aim was to describe the relation between history of atopy and laboratorial findings with DBPCFC results. It was included 58 patients that were distributed in two groups. Group 1 was composed of 39 patients (median age: 5,3 years; $1,6 \mathrm{M}: 1 \mathrm{~F}$ ) with suggestive history of $\mathrm{CMA}$ without recent anaphylaxis, and specific lgE to cow's milk (CM) and/or its fractions. In group 2 was included 19 patients (median age 8,3 years; 1,4 M:1F) where the CMA diagnosis was excluded based on clinical findings. The items evaluated in the adaptation of this method were: setting choice, kind of milk processing and vehicles, besides material and test performance. Day hospital was considered adequate for this test. Regarding to elected materials to offer the vehicle, opaque and sealed recipients showed more suitable to test demands. Vehicles more accepted were legumes soup and soy beverage 
and the most adequate $\mathrm{CM}$ to be offered was liquid and with low lactose concentration. The difficult observed in performance of DBPCFC do not compromise its execution, however the interpretation of the results was very difficult specially in patients with perioral wheals and unspecific clinical findings. There is an agreement Comparing adopted clinical and laboratorial criterion for definition of group 1 and 2 with DBPCFC results. In conclusion, the test proved to be feasible and safe and its adaptation is possible for $\lg \mathrm{E}$ mediated CMA diagnosis, being necessary to evaluate its reproducibility in other populations.

Descriptors: Food hypersensitivity/diagnosis, Cow's milk, Methodology, Child Adolescent 
Introdução 


\section{INTRODUÇÃO}

Alergia é uma reação de hipersensibilidade desencadeada por mecanismos imunológicos específicos, de acordo com a definição proposta na Revisão de Nomenclatura da EAACI NPS (European Academy of Allergology and Clinical Immunology: Nomenclature Position Statement) (JOHANSSON et al., 2004).

Define-se como reações adversas aos alimentos, qualquer reação anormal à ingestão do alimento. A Alergia Alimentar (AA) constitui uma reação adversa não-tóxica aos alimentos, que envolve mecanismos imunológicos. Entre esses, destacam-se os mediados pela imunoglobulina $\mathrm{E}$ ( $\operatorname{lgE}$ ) e aqueles não-mediados pela IgE (SAMPSON, 1999).

As reações adversas aos alimentos são queixas muito freqüentes na faixa etária pediátrica $(61,5 \%)$, porém apenas $4,2 \%$ podem ser atribuídas à AA lgE mediada (ROEHR et al., 2004). Entre as crianças menores de 1 ano, cerca de $5 \%$ a $15 \%$ apresentam sintomas sugestivos de reação adversa ao leite de vaca (LV). Nesta população, no entanto, a alergia pelo LV é confirmada em apenas $2 \%$ a $3 \%$ dos casos (HOST, 2002).

Nas últimas décadas tem sido constatado um aumento da prevalência das doenças alérgicas, incluindo as alergias alimentares. Estima-se que a prevalência da AA seja de aproximadamente $6 \%$ a $8 \%$ em crianças menores de 3 anos de idade (BOCK, 1987) enquanto que em adultos, a prevalência é menor atingindo 2\% dessa população (NIESTIJL, 1994). Entre os atópicos, a prevalência de AA parece ser maior em indivíduos com dermatite atópica 
(DA). ISOLAURI (1996) descreveu o envolvimento de alergia alimentar em 30 a $60 \%$ dos pacientes com dermatite atópica moderada ou grave através de teste de provocação oral duplo cego placebo controlado (TPODCPC). EIGENMANN et al. (1998) relataram que 35\% das crianças portadoras de dermatite atópica moderada ou grave têm os sintomas desencadeados por AA.

As manifestações clínicas da AA podem envolver a pele, o trato gastrintestinal, o trato respiratório ou mesmo o sistema cardio-vascular, sendo induzidas através de mecanismos imunológicos, após a ingestão de determinada proteína alimentar. A AA pode ser didaticamente classificada em dois grupos, de acordo com o mecanismo imunológico envolvido: AA mediada por IgE e AA não mediada por IgE, embora possa ocorrer AA por mecanismo misto.

Embora ocorra a ingestão de grande número de proteínas da dieta, apenas alguns alimentos são freqüentemente associados às manifestações clínicas. Os alérgenos alimentares capazes de estimular uma resposta imunológica apresentam, em sua maioria, as seguintes características: são glicoproteínas hidrossolúveis, apresentam peso molecular entre 10 a $70 \mathrm{kDa}$, são termoestáveis e resistentes a ácidos e proteases (SAMPSON, 1999). Com estas características, os alimentos mais envolvidos na AA são: o leite de vaca, soja, ovo, amendoim, trigo, castanhas, peixe e crustáceos (SICHERER \& SAMPSON, 2006). Entre esses, o leite de vaca é o mais frequente já que é o primeiro alimento oferecido à criança após o desmame, contendo muitas proteínas alergênicas. Por todos estes fatores, a Alergia às 
Proteínas do Leite de Vaca (APLV) merece enfoque especial na faixa etária pediátrica, sendo necessário o conhecimento das suas peculiaridades e prevalência nesta população.

O LV contém aproximadamente 30 a $35 \mathrm{~g} / \mathrm{L}$ de proteínas, sendo aquelas mais relacionadas à alergia alimentar, a $\beta$-lactoglobulina, a caseína e a a-lactoalbumina (WAL, 1998). Estudos em grandes populações de pacientes alérgicos têm mostrado que a maioria dos pacientes são sensibilizados a mais de uma proteína (GOLDMAN et al. 1963; WAL, 2004).

A proteína $\beta$-lactoglobulina ocorre naturalmente na forma de um dímero de $36 \mathrm{kDa}$ e não está presente no leite materno. Como característica, é bastante resistente à hidrólise ácida e à ação de proteases, facilitando que parte desta proteína seja absorvida no trato gastrintestinal na forma intacta.

A a-lactoalbumina bovina é uma proteína de 14,4 kDa e apresenta homologia com a a-lactoalbumina humana.

A caseína é a proteína que forma a parte sólida, quando da coagulação do leite de vaca, e apresenta várias isoformas, tais como: as-1, $\beta$-, as-2 e K-caseína (WAL, 2004). Caracteriza-se pela alta resistência a processamento térmico, embora seja sensível à ação de proteases. Mesmo seus fragmentos resultantes da ação proteolítica podem conservar parte da alergenicidade da proteína nativa.

$\mathrm{Na}$ literatura, existe grande variabilidade quanto à prevalência APLV, atingindo de $1,9 \%$ a $17 \%$ das crianças, mostrando a diversidade da faixa etária considerada e da metodologia diagnóstica utilizada, com poucos 
estudos utilizando o teste de provocação oral duplo cego placebo controlado (TPODCPC), considerado padrão ouro para o diagnóstico de APLV.

RONA (2007) realizou uma meta-análise sobre a prevalência de alergia alimentar em crianças e adultos, onde foram avaliados 934 artigos publicados nos últimos 18 anos, sendo que apenas 51 foram considerados adequados para análise. Os estudos com base em relatos dos próprios pacientes ou familiares foram mais freqüentes comparados aos baseados em métodos diagnósticos objetivos. Neste estudo, foi descrita uma prevalência de APLV que variou entre $1,2 \%$ a $17 \%$, sendo a primeira estimativa baseada em testes de provocação e a última, baseada em relatos de pacientes ou familiares.

Vários estudos sugerem aumento da prevalência de APLV em crianças menores de um ano de idade nas últimas décadas: 1,9\% ( $n=1079)$ JAKOBSSON \& LINDBERG (1979); $2,2 \%(n=1749)$ HOST \& HALKEN (1990); 2,8\% ( $n=1158)$ SCHRANDER et al (1993). BOCK \& SAMPSON (1994), através de estudo prospectivo utilizando testes de provocação oral sugeriram que a APLV afeta aproximadamente $2,5 \%$ das crianças abaixo de 3 anos de idade. Em artigo de revisão com dados publicados de 1967 a 2001, HOST (2002) encontrou uma prevalência de APLV no primeiro ano de vida de 2 a $3 \%$ nos países desenvolvidos. 


\section{Fatores de Risco para desenvolvimento de Alergia Alimentar}

O desenvolvimento e expressão clínica da AA depende da interação de fatores genéticos e ambientais (WAHN \& VON MUTIUS, 2001). Em relação aos fatores genéticos, o risco de atopia (alergia) aumenta se um dos pais ou irmão têm doença atópica ( 20 a $40 \%$ e 25 a 35\% respectivamente) e é maior se ambos os pais são atópicos (40 a 60\%) (BJÖRKSTEN, 2005). Também podem ser considerados fatores de risco para o desenvolvimento de alergia alimentar aquelas condições que interferem na defesa do trato gastrintestinal (TGI), alterando sua permeabilidade e a exposição precoce a alimentos (GARSIDE et al., 2004). $\quad$ O aleitamento materno exerce também um importante papel na defesa do organismo nos primeiros meses de vida, através da similaridade antigência da espécie e por conter fatores protetores imunológicos e não imunológicos. Estudos sugerem efeito protetor do aleitamento materno em lactentes com antecedente familiar positivo para atopia se forem amamentados exclusivamente pelo menos até os 4 meses de vida ou seja, sem a introdução de leite de vaca, fórmulas infantis e de alimentos complementares neste período (VAN ODJIK, 2003; SAARINEN \& KAJOSAARI 1995). A recomendação de dieta materna com a exclusão de alérgenos alimentares durante a gestação e lactação é controversa e carece de evidência científica.

Até recentemente, segundo as recomendações da Academia Americana de Pediatria para crianças com risco de atopia, a introdução do leite de vaca, ovo, peixe, nozes e amendoim deveria ocorrer somente após o 
primeiro ano de vida (AAP, 2000). Atualmente, porém, este conceito está sendo reavaliado, pois a introdução precoce de alimentos também tem sido apontada como indutora de tolerância oral (GREER, 2008).

\section{Fisiopatologia da Alergia Alimentar}

O sistema imunológico é responsável pelo reconhecimento de proteínas estranhas ao organismo e pela proteção contra microorganismos potencialmente nocivos, tais como: vírus, bactérias e fungos. O TGI é considerado o maior órgão linfóide do organismo e um importante local de contato entre o organismo e uma infinidade de proteínas alimentares e microrganismos. A lâmina própria intestinal é o maior local de produção de anticorpos do organismo e é onde $80 \%$ das células produtoras de anticorpos (células B ativadas) são encontradas. Através do mecanismo de tolerância oral, o sistema imune de mucosas do TGI reconhece e permite a presença da microbiota intestinal, bem como a aceitação das proteínas provenientes dos alimentos (ISOLAURI, 2001; BRANDTZAEG, 2002).

O mecanismo de tolerância oral envolve deleção ou anergia de células T reativas a antígenos específicos, associados à expansão da população de células $T$ regulatórias, secundária à produção de citocinas tolerogênicas, incluindo a interleucina 10 (IL-10) (FARIA \& WEINER, 2005). O papel desta interleucina na indução de tolerância tem sido bastante evidenciado por vários estudos mostrando associação entre níveis de IL-10 e 
desenvolvimento de tolerância a alimentos (CHEHADE \& MAYER. 2005, KARLSSON et al., 2004).

Muitos fatores têm sido considerados como importantes para o desenvolvimento da $\mathrm{AA}$, entre eles: características genéticas, fatores dietéticos, quebra dos mecanismos de defesa do TGI e não desenvolvimento ou quebra da tolerância oral aos alimentos. Qualquer interferência na relação de equilíbrio entre esses fatores pode facilitar o desenvolvimento de AA.

Vários mecanismos imunológicos participam da fisiopatologia da AA, em especial o mecanismo mediado por lgE. Este decorre da degranulação de mastócitos com liberação de mediadores, após o contato da $\lg E$ específica com o antígeno. As alergias alimentares não mediadas por $\lg \mathrm{E}$ envolvem outros mecanismos de hipersensibilidade, sendo o mais importante o tipo IV, mediado por células e envolvido na maioria das alergias alimentares com manifestações gastrintestinais.

A sensibilização ao alimento é a primeira etapa da AA mediada por $\lg \mathrm{E}$, caracterizando a formação de $\lg \mathrm{E}$ específica ao alérgeno alimentar. A sensibilização pode ocorrer através de diversas rotas de exposição, sendo a ingestão a mais freqüente. Através do aleitamento materno, antígenos da dieta materna também podem sensibilizar e desencadear reações alérgicas. Portanto, mesmo lactentes em aleitamento materno exclusivo podem apresentar alergia ao leite de vaca (HOST, 2002). Outras rotas de exposição e sensibilização aos alimentos, que não a oral, têm sido descritas. TAN et al.(2001) descreveram cinco casos de reações graves a alimentos após contato com a pele e inalação. Mesmo quando a barreira cutânea encontra- 
se intacta, alérgenos alimentares podem penetrar através da pele. Na rota inalatória, sintomas cutâneos podem ocorrer sem manifestações respiratórias concomitantes.

No processo de sensibilização, são produzidas lgE específicas que se ligam a receptores de alta afinidade $(F C € R I)$ presentes nas membranas de basófilos e mastócitos e em receptores de baixa afinidade (FC€RII), presentes em mastócitos, linfócitos, eosinófilos e plaquetas. Após um novo contato com o alérgeno, ocorre a ligação do antígeno alimentar à $\lg E$ específica, desencadeando a ativação e a degranulação destas células com a liberação de mediadores pró-inflamatórios como histamina, triptase, leucotrienos e prostaglandinas. Estes mediadores são responsáveis por reações inflamatórias imediatas caracterizadas por vasodilatação, contração da musculatura lisa e secreção de muco e podem também contribuir para a fase tardia (NOWAK-WEGRZYN \& SAMPSON, 2006). Além da sensibilização, é necessário que o mecanismo de tolerância oral não se estabeleça e que ocorra um desvio da resposta imune para o padrão Th2, com conseqüente produção de citocinas inflamatórias e desencadeamento de manifestações clínicas (van WIJK \& KNIPPELS, 2007).

\section{Manifestações Clínicas da Alergia Alimentar IgE mediada}

Embora não existam sinais ou sintomas que sejam patognomônicos de alergia alimentar, algumas manifestações clínicas são características do envolvimento do mecanismo lgE mediado. Estas reações são caracterizadas 
pelo rápido aparecimento dos sintomas clínicos geralmente até 2 horas após a exposição ao alimento, sendo a pele frequentemente acometida, seguida pelo TGI e trato respiratório (BOCK \& ATKINS, 1990).

As manifestações cutâneas incluem: urticária, urticária de contato, angioedema, eritema e o eczema. (CHAMPION, 1990) relatou que a alergia alimentar mediada por IgE era responsável por $20 \%$ dos casos de urticária aguda, enquanto na urticária crônica essa correlação ocorreria em apenas $1,4 \%$ dos casos).

As manifestações gastrintestinais incluem: a Síndrome da Alergia Oral, dor abdominal, náusea, diarréia, vômitos e refluxo gastro-esofágico. RANCE (1999) ressalta que a enteropatia está sempre presente em pacientes com alergia à proteína do leite de vaca.

As manifestações de alergia alimentar no trato respiratório são: obstrução, prurido e coriza nasais, espirros, dispnéia, tosse, hiperreatividade brônquica, edema de laringe e broncoespasmo. NOVEMBRE et a.(1988), descreveram que cerca de $6 \%$ das crianças asmáticas atendidas num ambulatório de pneumologia apresentavam broncoespasmo induzido por alimento. EIGENMANN \& SAMPSON (1998) relataram prevalência menor que $1 \%$ de rinite induzida por alimento, embora $25 \%$ a $80 \%$ de pacientes submetidos a teste de provocação alimentar apresentaram sintomas de rinite durante a realização deste exame. Frequentemente, as manifestações nasais podem ser acompanhadas de manifestações oculares, tais como: hiperemia, prurido e lacrimejamento,

As manifestações cardiovasculares são: taquicardia, arritmia, 
hipotensão, cianose e choque. Tais manifestações fazem parte dos quadros de anafilaxia. A anafilaxia tem sido definida como uma reação de hipersensibilidade grave, generalizada ou sistêmica, com risco de vida. $\mathrm{Na}$ alergia alimentar, estas manifestações frequentemente ocorrem nos 30 minutos após a exposição ao alimento desencadeante. Segundo SAMPSON et al., (1992) os principais fatores de risco relacionados ao desenvolvimento de reações anafiláticas são: anafilaxia anterior, história de asma, alergia ao amendoim, adolescência e concentrações elevadas de lgE sérica específica.

\section{Abordagem diagnóstica da Alergia Alimentar}

O estabelecimento de um diagnóstico acurado de alergia alimentar é uma tarefa difícil, pois os sintomas são inespecíficos. O conhecimento da fisiopatologia torna a investigação diagnóstica mais objetiva. O diagnóstico baseia-se na história clínica, exame físico e exames laboratoriais, entre eles: pesquisa de IgE específica através do teste cutâneo de hipersensibilidade imediata (Prick test ou ImmunoCAP ${ }^{\circledR}$ associados aos testes de provocação oral, que podem ser abertos ou cegos (VANDENPLAS et al., 2007). No Brasil, foi publicado recentemente o "CONSENSO BRASILEIRO SOBRE ALERGIA ALIMENTAR 2007", elaborado pela Sociedade Brasileira de Pediatria e Associação Brasileira de Alergia e Imunopatologia. Neste consenso encontram-se diretrizes para a investigação diagnóstica e o manejo de pacientes com suspeita de AA.

O primeiro passo é realizar uma anamnese detalhada para obter 
principalmente as seguintes informações: antecedente de atopia entre os pais ou irmãos, antecedente de prematuridade ou baixo-peso, doença perinatal, contato com LV no berçário ou precocemente, tempo de aleitamento materno, ingestão materna de LV ou derivados durante o aleitamento, idade do aparecimento das manifestações clínicas bem como as características destas manifestações. Dados sobre a idade de início dos sintomas, intervalo de tempo entre a ingestão do alimento e o aparecimento dos sintomas, a quantidade responsável pelo desencadeamento de sintomas e o modo de preparo do alimento, órgãos acometidos e reincidência são primordiais para a investigação diagnóstica. Um diário alimentar pode ser útil para complementar a história clínica.

O exame físico minucioso é importante com atenção à presença de sinais de outras doenças alérgicas como a dermatite, rinite e asma. Atenção especial deve ser dada à avaliação nutricional, já que muitas crianças recebem dietas restritivas sem adequada reposição de nutrientes.

\section{Exames Laboratoriais}

Alguns exames laboratoriais, como a contagem de eosinófilos séricos e a concentração sérica total de IgE são inespecíficos para alergia alimentar, acompanhando frequentemente outras situações como verminoses e mesmo outras doenças atópicas. Deve ser ressaltado que muitos pacientes com alergia alimentar, mesmo com manifestação de anafilaxia, podem apresentar 
resultados normais para IgE total e contagem de eosinófilos no sangue periférico.

A pesquisa das IgE específica é geralmente erroneamente valorizada como diagnóstico de $\mathrm{AA}$, quando na realidade indica apenas sensibilização aos alimentos. O teste de puntura de leitura imediata (Prick test) tem sido utilizado para detecção de IgE específica para alimentos, mesmo em crianças de baixa idade (nos primeiros meses de idade). A técnica deve seguir as normas predeterminadas, utilizando-se lancetas e extratos padronizados. O controle negativo é essencial para detectar reação inespecífica, como aquela que ocorre por dermografismo ou lesão traumática. É considerado positivo o teste cujo diâmetro da pápula seja maior ou igual a $3 \mathrm{~mm}$ em relação ao controle negativo (BOCK, 1988). O significado do teste positivo se relaciona apenas à sensibilização ao alimento, sem necessariamente indicar alergia alimentar. No caso de positividade ao teste, como o valor preditivo positivo é de apenas $50 \%$, o resultado deve ser confirmado pelo TPODCPC (SAMPSON \& ALBERGO, 1984). Por outro lado, Hill et al. (2004) sugeriram que crianças menores de 2 anos de idade com diâmetro da pápula maior ou igual a $8 \mathrm{~mm}$ para LV, ovo ou amendoim poderiam ser dispensadas do TPODCPC, já que estes valores estão associados a um valor preditivo positivo maior que $95 \%$. Quando são utilizados extratos de alta qualidade, o Prick test negativo tem valor inquestionável na exclusão de AA mediada por IgE (valor preditivo negativo de $95 \%$ ). Além do uso de extratos padronizados, o teste pode ser realizado com o alimento in natura (Prick to Prick). Estima-se que para alguns 
alimentos como o leite e frutas, isto possa acarretar em aumento do valor preditivo positivo (RANCE et al.,1997). O Prick test é contra-indicado em pacientes com história de sintomatologia grave e recente ao alimento, dermografismo, dermatites extensas, uso concomitante de anti-histamínicos, uso de beta-bloqueadores e em pacientes com discrasias sangüíneas, que predisponham ao sangramento. Além disso, o teste deve ser realizado em ambiente adequado e por profissional capacitado para atendimento de possíveis reações graves.

O radioactive allergosorbent test (RAST) tem a finalidade de detectar, "in vitro," a IgE específica ao alimento no soro do paciente. Trata-se de um teste semi-quantitativo, sendo seu resultado expresso em classes, que variam de 0 a 4 . O valor preditivo deste teste é semelhante ao do Prick test, quando considerado como positivo classe igual ou superior a 3 . Em pacientes que apresentem altas concentrações de $\lg E$ sérica total, cuidado especial deve ser dado à sua interpretação, uma vez que podem ocorrer ligações inespecíficas. Porém, em um estudo realizado por CELIK-BILGILI et al.(2005), 60\% dos pacientes com RAST classe I, 50\% com classe II, 30\% com classe III e $20 \%$ com classe IV apresentaram resultados negativos quando submetidos a testes de provocação oral. O método ImmunoCAP ${ }^{\circledR}$ representa uma evolução do RAST, já que utiliza maior superfície de contato para ligação com a IgE específica, sendo um exame mais adequado por ser quantitativo. 
Estudos recentes tentam estabelecer níveis de lgE (método ImmunoCAP ${ }^{\circledR}$ ) para cada alimento, acima dos quais os paciente poderiam ser dispensados da realização do TPODCPC para confirmar o diagnóstico (valor preditivo maior que 95\%). SAMPSON et al.(2001) estimaram o valor de $15 \mathrm{kU} / \mathrm{L}$ para LV como ponto de decisão. Em adição, GARCIA-ARA et al. (2001) estimaram a concentração de $5 \mathrm{kU} / \mathrm{L}$ para crianças menores de 2 anos de idade. Trabalho semelhante realizado no serviço de Alergia e Imunologia do Instituto da Criança do HCFMUSP revelou, como ponto de decisão para diagnóstico, valor maior ou igual a $11 \mathrm{kU} / \mathrm{L}$ para leite de vaca, sugerindo que os resultados variam de acordo com a população estudada (GUSHKEN et al., 2006). Mais estudos são necessários para a determinação dos pontos de decisão, devendo-se levar em conta as diferenças em relação à idade e populações estudadas.

As Dietas de Eliminação para fins diagnósticos foram muito utilizadas no passado, representando importantes ferramentas para auxiliar no diagnóstico de $\mathrm{AA}$, quando o alimento ofensor é conhecido. O alimento suspeito é retirado da dieta do paciente. Se ocorrer melhora clínica evidente é bastante provável o envolvimento deste alimento na patogenia da doença e o TPODCPC deverá ser então indicado para a confirmação do diagnóstico.

Os Testes de Provocação Oral (TPO) são métodos importantes para o diagnóstico de alergia alimentar. Devem ser realizados sempre sob supervisão médica em tempo integral e em locais equipados para atendimento de possíveis reações graves. Mesmo pacientes com história de reações anteriores leves ou moderadas podem evoluir para reações graves 
durante o TPO. Existem três tipos de TPO: aberto, simples cego e duplo cego placebo controlado.

Tipo aberto: É indicado para excluir a suspeita sobre determinado alimento. O alimento é oferecido sob observação médica. No entanto, não é indicado para a confirmação do diagnóstico. Após um resultado positivo, o paciente deve ser submetido ao TPODCPC. Segundo BOCK (1988), cerca de $50 \%$ das provocações abertas positivas não são confirmadas posteriormente no TPODCPC. NIGGEMANN \& BEYER (2007) sugerem o TPO aberto para crianças menores de 1 ano de idade. Se apresentarem sintomas imediatos e objetivos, podem ser dispensados da confirmação do diagnóstico de AA pelo TPODCPC.

Simples cego: Neste exame, tanto o paciente quanto 0 acompanhante não sabem o momento em que está sendo oferecido o alimento, apenas o médico e nutricionista conhecem o conteúdo das porções. Desta forma, evita-se a auto-sugestão ou, no caso de crianças pequenas, a sugestão do acompanhante.

Duplo cego: Entre todos os exames disponíveis, o teste de provocação oral duplo cego placebo controlado (TPODCPC) é o método que apresenta maior especificidade e sensibilidade para o diagnóstico de AA. Nas últimas décadas, o TPODCPC tem sido considerado "Padrão Ouro" para o diagnóstico de alergia alimentar, segundo vários autores. (MAY, 1976; BOCK et al.,1988; SAMPSON \& METCALFE, 1992; BRUYNZEELKOOMEN et al., 1995; WILLIAMS \& BOCK, 1999; NIGGEMANN \& BEYER, 2007). Por definição, um teste é considerado padrão ouro, quando apresenta 
qualidades que o permitam ser utilizado como referência para a determinação das características operacionais de um novo método ou teste diagnóstico (DÓRIA-FILHO, 1999). Para pacientes com história bastante sugestiva de AA e com pesquisa de lgE específica positiva, o TPODCPC é preferível evitando-se TPO aberto.

O TPODCPC tem como principal objetivo, a reprodução dos sintomas desencadeados em uma exposição natural sem a interferência da sugestão tanto por parte do paciente quanto dos observadores (acompanhante e médico). Portanto, em comparação ao TPO aberto ou simples cego, o TPODCPC tem como principal vantagem o menor risco de falsos positivos. Consiste em duas fases: em uma delas, é oferecido o alimento a ser investigado e em outra, o placebo, ambos oferecidos em doses crescentes em intervalos regulares adicionados a veículos. O veículo é o material que acomoda o alimento a ser testado e tem a função de mascarar o odor, sabor, textura e cor tanto do alimento a ser testado quanto do placebo, não permitindo que existam diferenças entre as porções. O veículo também deve permitir que o alimento a ser testado seja oferecido em volumes pequenos, com várias doses em pouco tempo e em quantidade suficiente para desencadear sintomas no paciente com AA.

A seqüência das fases do exame é conhecida apenas pelo nutricionista, responsável pela randomização. Tanto o médico avaliador e a equipe de enfermagem quanto o paciente e o responsável desconhecem o que está sendo oferecido junto ao veículo. Desta forma, elimina-se a sugestão na interpretação tanto do avaliador e observadores, quanto do 
paciente.

O TPODCPC permite também estimar a dose de alimento necessária para induzir sintomas e é um importante aliado durante o seguimento e avaliação evolutiva dos pacientes com alergia alimentar, já que, conforme a história natural desta patologia, muitos tornam-se tolerantes ao alimento ao longo do tempo. Mesmo após a aquisição de tolerância clínica, os exames laboratoriais para pesquisa de IgE específica podem permanecer positivos durante anos, sendo necessária a confirmação da tolerância clínica através do TPODCPC. WILLIAMS \& BOCK (1999) sugerem que mesmo as crianças com anafilaxia a LV ou ovo, poderiam realizar o TPODCPC para estes alimentos após vários anos do episódio inicial, já que existe uma expectativa de tolerância a estes alimentos após 3 anos de dieta de exclusão. VLIEG-BOERSTRA et al.(2008) avaliaram 441 TPODCPC realizados em crianças, sendo que 21 delas apresentaram história de anafilaxia anterior ao exame (período de tempo entre a anafilaxia e o exame variou de 0,3 a 12,8 anos, mediana de 4,25 anos). Entre estas, 71\% apresentaram TPODCPC positivo, porém não houve a ocorrência de nenhuma reação grave e não foi necessária a utilização de epinefrina. Assim, estes autores concluem que o TPODCDC pode ser realizado em crianças com história de anafilaxia anterior, embora exista risco potencial de reação grave. NIGGEMANN \& BEYER (2007), porém, contra-indicam este teste em casos de anafilaxia recente e em pacientes com asma não controlada.

Resultados de TPODCPC falso-negativos podem ocorrer entre 1,8\% 
a 5\% (BOCK \& ATKINS, 1990; WILLIAMS \& BOCK, 1999; SICHERER et al., 2000; CAFFARELLI \& PETROCCIONE, 2001) decorrentes de doses insuficientes para desencadeamento de sintomas, ausência de contato do alimento com a pele perioral e mucosa oral ou alteração da alergenicidade durante o preparo do alimento a ser testado.

Resultados falso-positivos podem ocorrer durante o exame devido à ansiedade do paciente, com manifestações de reações vaso-vagais não relacionadas à ingestão de proteína alimentar. Estes pacientes podem apresentar: bradicardia, sudorese, palidez cutânea, confusão mental, perda de consciência, náuseas, vômitos, liberação esfincteriana e hipotensão. VLIEG-BOERSTRA et al (2007) referem reações com placebo em 12,9\% de 132 TPODCPC.

O TPODCPC tem como principais desvantagens, o tempo necessário para a sua realização, os custos envolvidos, a dificuldade na interpretação dos resultados e a possibilidade de reações graves, devendo ser realizado em local com infra-estrutura adequada e com equipe capacitada ao atendimento específico.

Na faixa etária pediátrica uma das maiores dificuldades é a escolha do veículo a ser utilizado para esconder o alimento, já que o uso de cápsulas não é viável. Em muitos estudos, os alimentos a serem testados são oferecidos adicionados a outros alimentos (BOCK et al.,1988; NIGGEMANN et al.,1994; HUIJBERS et al., 1994; ISOLAURI \& TURJANMAA, 1996). No entanto, o maior desafio é em relação ao aumento das doses do alimento a ser testado durante o exame, pois suas características tornam-se cada vez 
mais difíceis de serem mascaradas. Na literatura, podemos encontrar diversos estudos que utilizam alimentos como veículos durante o TPODCPC (BOCK et al., 1988; HUIJBERS et al., 1994; NIGGEMANN et al., 1994; ISOLAURI \& TURJANMAA, 1996; BINDSLEV-JENSEN, 2001). Porém, em alguns estudos, a exata composição dos veículos utilizados não é claramente descrita ou são veículos considerados de difícil aplicabilidade devido a fatores como: alto custo, baixa palatabilidade e preparo laborioso. Através da literatura científica, observam-se que vários esforços têm sido realizados com a intenção de padronizar este importante método diagnóstico (MAY,1976; BOCK et al., 1978, BAHNA \& FURUKAWA, 1983; METCALFE \& SAMPSON, 1990; NIGGEMANN,1994; BINDSLEV-JENSEN, 2004, VLIEG-BOERSTRA et al.,2004; NIGGEMANN \& BEYER, 2007; WILLIAMS \& BOCK, 1999; SICHERER, 1999; EIGNMANNPA, 2004).

Outros testes diagnósticos para AA têm sido utilizados, mas ainda carecem de adequada padronização, tais como o Patch Teste Atópico e a

\section{Provocação Labial.}

O Patch Teste Atópico avalia a presença de reações de hipersensibilidade imediata e tardia. Em pacientes com dermatite atópica, foram realizadas biópsias durante o teste, mostrando evidências tanto de resposta TH1 como TH2. Inicialmente, células T com padrão de secreção de citocinas TH2 foram encontras e células $T$ com padrão de secreção TH1 predominaram após 48 horas da aplicação do teste. Nos últimos anos, estudos têm sido realizados com a finalidade de padronizar este método para auxiliar na investigação da AA (TURJANMAA et al., 2006). No entanto, 
até o momento, seu uso não é recomendado como rotina para a prática clínica.

O Teste de Provocação Labial é uma técnica diagnóstica que avalia o aparecimento de reações imediatas após o contato com o alimento na mucosa labial. Podem ser utilizados extratos padronizados ou o alimento in natura como nos casos de reações a frutas ou vegetais (RANCÉ \& DUTAU, 1997), porém sua interpretação ainda necessita maior padronização.

\section{Tratamento e História Natural da Alergia Alimentar}

O tratamento da APLV é realizado através da exclusão do alimento desencadeante dos sintomas, da dieta do paciente. É fundamental uma correta abordagem diagnóstica e a orientação e acompanhamento dos pacientes com AA através de uma equipe multi-profissional. É necessário o acompanhamento médico periódico para reforçar as orientações quanto à exclusão total do alérgeno: orientar sobre a presença do alimento também em cosméticos e medicamentos, avaliar o desenvolvimento pônderoestatural, a evolução dos exames laboratoriais de controle (dosagem das lgE específicas) e o possível aparecimento de outras doenças alérgicas (marcha atópica) (HAHN \& BACHARIER,2005). O médico é responsável pela prescrição de suplementos como o cálcio, em casos de necessidade. A participação na equipe multiprofissional de um profissional experiente na avaliação nutricional deste paciente (nutricionista e nutrólogo) auxilia na orientação sobre a exclusão do alérgeno desencadeante (leitura de rótulos e 
termos correlatos como caseína, soro de leite, sabor manteiga), a substituição do leite de vaca para as crianças que não podem ser amamentadas ou mesmo para crianças maiores, mantendo equilíbrio adequado do ponto de vista nutricional. Deve ser ressaltado que devido ao alto risco de reações cruzadas, a substituição por leite de outros mamíferos (caprinos e ovinos) não é recomendada. As fórmulas infantis especiais com proteínas de leite de vaca ou soja extensamente hidrolisadas e as fórmulas elementares podem ser utilizadas, porém são caras e apresentam baixa palatabilidade. Em nosso meio, são utilizadas frequentemente as fórmulas infantis com proteínas de soja em pacientes com APLV lgE mediada, maiores de 6 meses de idade, devido ao custo mais acessível e aceitabilidade. Crianças com AA freqüentemente perdem a sensibilidade a alérgenos comuns como leite, ovo, soja e trigo em poucos anos. No entanto, o mesmo não ocorre com a alergia ao amendoim e nozes, podendo persistir por toda a vida (BOCK, 1988).

Segundo HOST (2002), o prognóstico da APLV é bom com taxa de remissão de 45 a $50 \%$ até 1 ano, 60 a 75\% até 2 anos e 85 a $90 \%$ até 3 anos de idade. Neste artigo de revisão, o autor descreve o desenvolvimento de alergia a aeroalérgenos nestas crianças com APLV em 50 a 80\% antes da puberdade. Em um estudo mais recente, SKRIPAK et al.(2007) descreveram resolução da APLV em $19 \%$ aos 4 anos de idade, $42 \%$ aos 8 anos, $64 \%$ aos 12 anos e $79 \%$ aos 16 anos. Os fatores preditivos para persistência da APLV encontrados foram os altos níveis de lgE específica e a coexistência de asma e rinite. 
Embora o TPODCPC seja um método diagnóstico de extrema importância na AA, não existe em nosso meio uma padronização em relação aos materiais e métodos para a sua execução, principalmente na faixa etária pediátrica. A adaptação do teste às nossas condições é necessária para facilitar o uso do teste na prática clínica institucional diária e para permitir a comparação dos resultados obtidos, quando realizado de forma evolutiva.

A finalidade deste estudo é a adaptação deste método no Instituto da Criança do Hospital das Clínicas da FMUSP, para o diagnóstico de alergia às proteínas do leite de vaca mediada por IgE em crianças e adolescentes. Este estudo propõe-se a realizar uma adaptação à metodologia deste teste descrita por WILLIAMS \& BOCK, 1999, principalmente em relação aos materiais utilizados durante o exame e ao esquema de administração das doses. Sentiu-se também a necessidade de adaptar as orientações pré e pós teste aos pacientes deste serviço.

A experiência com esta adaptação foi descrita quanto ás dificuldades de execução, interpretação dos resultados e comparação dos dados epidemiológicos e laboratoriais entre dois grupos de pacientes: com provável APLV IgE mediada e outro, onde este diagnóstico foi descartado após avaliação dos dados de história clínica. 
Objetivos 


\section{OBJETIVOS}

O objetivo principal deste estudo é:

Adaptar o teste de provocação oral duplo cego placebo controlado no Instituto da Criança do Hospital das Clínicas da FMUSP para o diagnóstico de alergia às proteínas do leite de vaca mediada por IgE em crianças e adolescentes.

O objetivo secundário deste estudo é:

Descrever a relação entre os antecedentes de atopia e os dados de laboratoriais e os resultados dos testes de provocação oral duplo cego placebo controlado. 
Métodos 


\section{MÉTODOS}

\section{CASUÍSTICA}

A adaptação do TPODCPC foi realizada na Unidade de Alergia e Imunologia do Instituto da Criança do HCFMUSP, no período de 2003 a 2008 incluindo pacientes provenientes do ambulatório de Alergia Alimentar desta unidade.

\subsection{Critérios de inclusão:}

Foram admitidos para a casuística, pacientes com as seguintes características:

- Idade maior que 1 ano e menor que 18 anos que preencheram os seguintes critérios:

Grupo 1: História sugestiva de APLV IgE mediada*, sem relato de episódio de anafilaxia recente (período menor que dois anos), com pesquisa positiva de lgE específica para proteínas do LV (Prick test LV e/ou frações maior ou igual a $3 \mathrm{~mm}$ do controle negativo e/ou ImmunoCAP $^{\circledR}$ maior ou igual a 3,5 $\mathrm{kU} / \mathrm{L}$ para LV e/ou frações) e que foram encaminhados ao ambulatório de Alergia Alimentar do Instituto da Criança do HCFMUSP para o diagnóstico de alergia a este alimento $(n=39)$. 
Considerou-se:

*História sugestiva de APLV IgE mediada:

- História de anafilaxia, desencadeada após exposição a proteínas de LV ou

- Presença de atopia** (familiar ou pessoal) e

- História clínica com manifestações compatíveis com aquelas relacionadas à $A A \lg E$ mediada até 2 horas após a ingestão de proteínas do LV.

** A atopia familiar positiva incluindo: pai, mãe e/ou irmão com asma, rinoconjuntivite, alergia alimentar e/ou dermatite atópica e Atopia pessoal positiva como: asma, rinoconjuntivite, alergia alimentar e/ou dermatite atópica.

Grupo 2: Pacientes cujo diagnóstico de APLV foi excluído com base nos dados de história clínica (sintomas inespecíficos após a ingestão de leite e tolerância a derivados de leite / sintomas após mais que 6 horas da ingestão).

\subsection{Critério de exclusão:}

Os critérios de exclusão basearam-se naqueles propostos por NIGGEMANN \& BEYER (2007):

- Reação anafilática recente (intervalo de tempo menor que dois anos) altamente sugestiva decorrente de ingestão do LV e com pesquisa de IgE específica positiva

- Asma não controlada 


\subsection{Constituição final da casuística:}

Dos 60 TPODCPC realizados, foram excluídos 2 por dificuldades técnicas apresentadas pelos pacientes durante o exame e não finalização do mesmo, sendo necessário submetê-los apenas ao teste aberto. Nestes dois casos, houve recusa na aceitação das porções devido ao sabor: em um paciente, suco de maçã (Yakult@) e bebida à base de soja de morango e maracujá (Tonyu®) em outro.

\subsection{Descrição dos dados demográficos dos 58 pacientes incluídos no} estudo:

A tabela 1 resume os dados demográficos e presença de atopia entre os pacientes incluídos neste estudo.

Tabela 1- Descrição dos dados demográficos e presença de atopia familiar e pessoal dos 58 pacientes dos grupos 1 e 2 que realizaram o Teste de Provocação Oral Duplo Cego Placebo Controlado

\begin{tabular}{ccccc}
\hline & IDADE & ATOPIA & ATOPIA \\
& $\begin{array}{c}\text { SEXO } \\
\text { (M:F) }\end{array}$ & $\begin{array}{c}\text { AO EXAME } \\
\text { (MEDIANA) }\end{array}$ & FAMILIAR & PESSOAL \\
\hline $\begin{array}{c}\text { GRUPO } 1 \\
\text { n= 39 } \\
\text { GRUPO 2 } \\
\text { n= 19 }\end{array}$ & 1,6 & $\begin{array}{c}5,3 \\
\text { anos } \\
8,3\end{array}$ & $(28 / 39) 72 \%$ & $(30 / 39) 77 \%$ \\
\hline
\end{tabular}

A idade do início dos sintomas de APLV referidas na história clínica dos pacientes do grupo 1 variou de 15 dias a 1,6 anos (mediana 4 meses).

Os pacientes do grupo 1 apresentavam as seguintes atopias pessoais relatadas pelo responsável: rinite $(n=16)$, asma $(n=11)$, dermatite atópica 
$(n=7)$, conjuntivite $(n=2)$, alergia a ovo $(n=3)$ e alergia a camarão $(n=1)$. Os pacientes do grupo 2 apresentavam história das seguintes atopias pessoais: rinite $(n=7)$, asma $(n=5)$.

A tabela 2 resume os dados laboratoriais dos pacientes que realizaram o TPODCPC.

Tabela 2 - Descrição dos dados laboratoriais de 58 pacientes dos grupos 1 e 2 submetidos ao Teste de Provocação Oral Duplo Cego Placebo Controlado

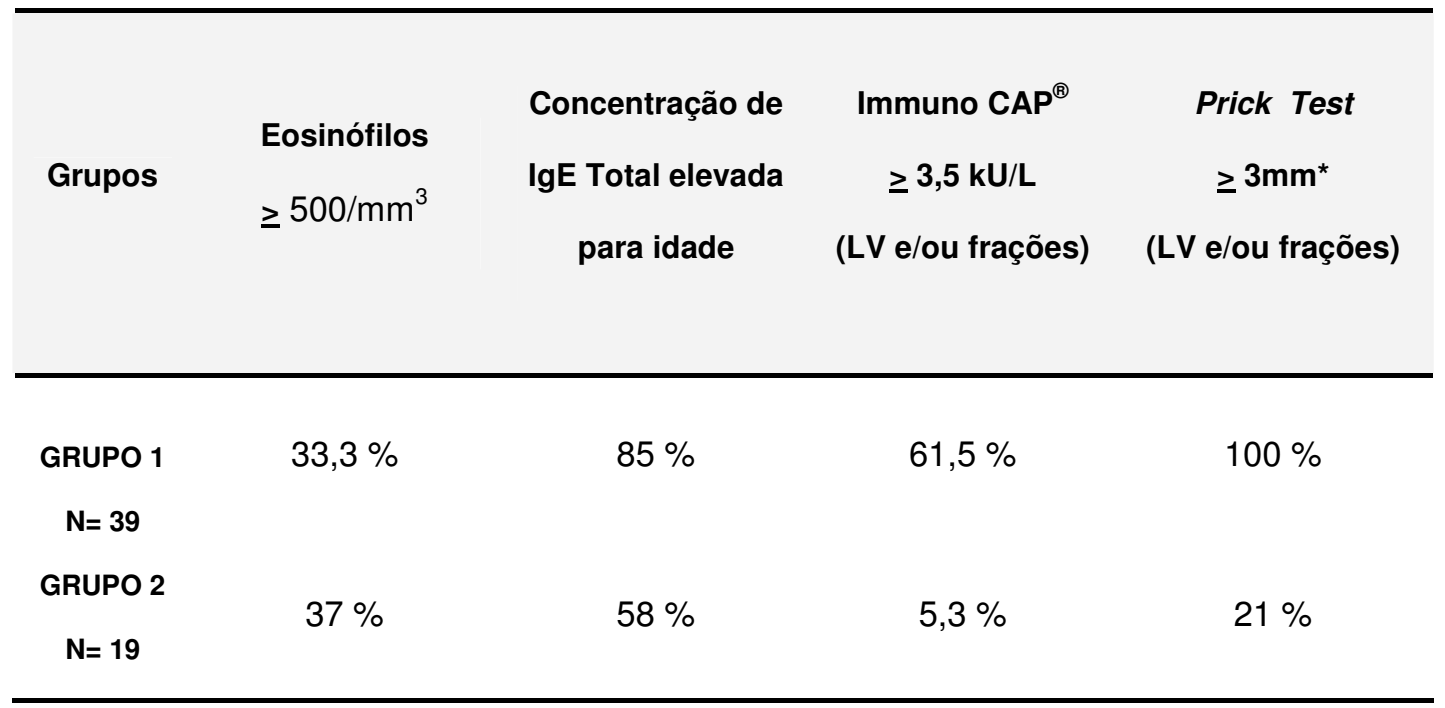

* em relação ao controle negativo

\section{METODOLOGIA}

O estudo constou das seguintes etapas:

\subsection{Fase experimental}

2.2 Fase de execução dos TPODCPC

2.3 Descrição e análise dos dados obtidos no desenvolvimento do TPODCPC adaptado 


\subsection{Fase experimental}

\subsubsection{Idealização do TPODCPC adaptado:}

Para a adaptação do teste, alguns pontos foram padronizados:

- Condições do local para a realização dos testes e escolha dos profissionais envolvidos

- Equipamentos e materiais necessários para o preparo das porções dos testes

- Veículos a serem utilizados

- Esquema para a administração do teste

\subsubsection{A escolha do local para a realização do TPODCPC:}

Os exames foram realizados no Hospital Dia do Instituto da Criança do HCFMUSP que possui as condições necessárias para o atendimento de possíveis reações graves. As enfermarias possuem sistemas de ventilação e iluminação adequados (artificial e natural), apresentam condições para atividades lúdicas com as crianças e também disponibilizam poltronas confortáveis para os acompanhantes. Possuem também divisórias reversíveis ao redor dos leitos para o atendimento inicial de casos graves.

Durante a fase de adequação, optou-se por não utilizar 0 ar condicionado na enfermaria onde o exame seria realizado, para evitar o desencadeamento de sintomas respiratórios. As janelas são protegidas com telas para evitar a entrada de insetos e puderam permanecer abertas para 
melhor circulação do ar ambiente. Houve a necessidade de se utilizar o ar condicionado apenas nos dias muito quentes.

\subsubsection{Profissionais envolvidos diretamente na realização do TPODCPC:}

O médico pesquisador e a equipe de enfermagem permaneceram em tempo integral junto aos pacientes durante os exames. A nutricionista foi a responsável pelo preparo, randomização e armazenamento em geladeira de todas as porções pertencentes aos testes e, algumas vezes, sua presença foi solicitada durante o teste para que o veículo fosse substituído. O médico não teve conhecimento sobre o conteúdo das porções durante o teste. Um acompanhante maior que 18 anos, responsável pelo paciente, permaneceu também em tempo integral ao lado do paciente. No local onde os exames foram realizados, contamos também com a presença de um médico intensivista para auxílio nos casos de possíveis manifestações graves.

\subsubsection{Materiais necessários para a realização do TPODCPC:}

Para evitar contaminação cruzada, as fases do teste foram preparadas e armazenadas em tempos diferentes, utilizando-se materiais descartáveis. Todas as porções foram realizadas no mesmo dia do teste e armazenadas em geladeira. Para as porções que necessitavam de aquecimento como a sopa de legumes, utilizou-se o forno microondas .

O alimento a ser testado pode ser utilizado em sua forma natural, 
purificada ou liofilizada. A forma de apresentação do LV pode ser em pó, pasteurizada, desnatada ou semi-desnatada (BOCK et al., 1988; VLIEGBOERSTRA et al., 2004).

Para a utilização de materiais industrializados foram observadas as datas de validade dos produtos.

\subsubsection{Equipamentos e materiais necessários para o preparo das} porções do teste

- Copos, colheres e canudos descartáveis

- Etiquetas para identificação das porções

- Seringas

- Geladeira, forno mlcroondas

- Leite de vaca na forma líquida

- Placebo

- Veículo

\subsubsection{Materiais necessários para a realização do exame}

\section{Materiais e equipamentos para assistência ao paciente}

- Balança, esfigmomanômetro, termômetro

- Estetoscópio

- Otoscópio

- Oxímetro de Pulso

- Aparelho de medida do pico de fluxo expiratório (Peak Flow)

- Material para acesso venoso

- Sonda para aspiração de VAS

- Material para lavagem gástrica

- Material para intubação

- Ambú com reservatório e máscara

- Desfibrilador 


\section{Medicamentos}

- Soro Fisiológico

- Broncodilatador inalatório

- Adrenalina (1:1000)

- Oxigênio

- Corticosteróides

- Anti-histamínicos preparação parenteral

- Drogas para sedação

\subsubsection{Tempo necessário para o preparo das porções do teste}

Foram necessários cerca de 60 minutos para o preparo de duas fases de cada teste (para um paciente), reduzindo-se este tempo para 90 minutos para o preparo de quatro fases para dois pacientes concomitantes.

\subsubsection{A escolha dos veículos}

Nesta fase, foram realizadas degustações para a escolha dos veículos. A primeira degustação foi realizada em 2003 com a colaboração voluntária de médicos da Unidade de Alergia e Imunologia do Instituto da Criança do HCFMUSP, sob supervisão da nutricionista do grupo. A segunda degustação foi realizada em 2004 após ter sido constatada a necessidade de novas opções para serem utilizadas como veículos. Novamente, contouse com a colaboração dos médicos da equipe, que avaliavam o quanto conseguiam identificar a presença do alimento teste em relação ao placebo e a palatabilidade da apresentação.

A escolha dos veículos baseou-se no preenchimento dos critérios utilizados para definir um bom veículo (HUIJBERS et al.,1994): 
- Ter um sabor agradável

- Ter a capacidade de acomodar o LV e o placebo, mascarando o odor, sabor, textura e cor de ambos, não permitindo que existam diferenças entre as porções.

- Ter a capacidade de mascarar o LV e o placebo mesmo com pequeno volume, pois grandes volumes podem alterar o funcionamento do trato gastrintestinal.

- Permitir que o LV seja oferecido em volumes pequenos, com várias doses em pouco tempo e em quantidade suficiente para desencadear sintomas no paciente com APLV e evitar falsos negativos nos TPODCPC.

- Possuir poucos ingredientes e uma composição tolerada pelo paciente

- Possibilitar um preparo rápido e simples, sem o risco de diminuir a alergenicidade do LV durante o preparo

- Ser acessível e de baixo custo (disponibilidade)

- Não ser de uso rotineiro pelo paciente para evitar o reconhecimento de produtos adicionados (LV ou Placebo)

- Ser termoestável, facilitando a conservação e o transporte durante o teste.

- Apresentar diferente composição protéica em relação ao LV: evitar leite de outros mamíferos como veículo

-Ser uma opção aceita pelo responsável do paciente

Os alimentos utilizados como veículos estão listados com seus respectivos ingredientes (Tabela 3): 


\section{VEÍCULOS}

\begin{tabular}{|c|c|}
\hline $\begin{array}{l}\text { Bebidas à base de soja } \\
\text { Tonyu }^{\circledR}\end{array}$ & $\begin{array}{l}\text { Extrato de soja, suco de fruta (sabores: morango, maracujá, } \\
\text { abacaxi, maçã), açúcar, estabilizante pectina cítrica, } \\
\text { acidulante ácido cítrico, aroma e corante natural, carmim } \\
\text { cochonilha (INS 120) no suco de morango. }\end{array}$ \\
\hline Sopa de Legumes & $\begin{array}{l}\text { Carne de frango, mandioquinha, cenoura, acelga, arroz, } \\
\text { salsa, óleo e sal }\end{array}$ \\
\hline Suco de uva Del Valle ${ }^{\circledR}$ & $\begin{array}{l}\text { Água, suco e polpa de uva concentrados, açúcar, ácido } \\
\text { cítrico, carboximetilcelulose de sódio (estabilizante), aroma } \\
\text { idêntico ao natural de uva, ácido ascórbico, corante natural } \\
\text { urucum, antiespumante polimetilsiloxano }\end{array}$ \\
\hline Suco de maçã Yakult ${ }^{\circledR}$ & Suco de maçã concentrado e água, aroma natural de maçã \\
\hline Suco de uva Maguary ${ }^{\circledR}$ & $\begin{array}{l}\text { Água e suco concentrado de uva, aroma natural de uva e } \\
\text { conservantes metabissulfito de sódio e benzoato de sódio }\end{array}$ \\
\hline Extrato de soja Ades ${ }^{\circledR}$ & $\begin{array}{l}\text { Extrato de soja, água, açúcar, sal, vitaminas, aromatizante } \\
\text { idêntico ao natural de baunilha, espessante goma, } \\
\text { carragena, estabilizante lecitina de soja }\end{array}$ \\
\hline $\begin{array}{l}\text { Suco de laranja com acerola } \\
\text { Ades }^{\circledR}\end{array}$ & $\begin{array}{l}\text { Água, extrato de soja, açúcar, suco concentrado de frutas, } \\
\text { maltodextrina, vitaminas e minerais (B1, B2, B3, B6, B12, C, } \\
\text { ácido fólico, ferro e zinco), acidulante ácido cítrico, } \\
\text { estabilizante pectina, goma guar e cloreto de cálcio, } \\
\text { aromatizante (aroma idêntico ao natural de frutas cítricas), } \\
\text { corantes urucum, cúrcuma e betacaroteno, edulcorante } \\
\text { sucralose }\end{array}$ \\
\hline Manjar & Leite de côco, gelatina incolor, açúcar, baunilha \\
\hline
\end{tabular}

\section{COMPOSIÇÃO}


Tomou-se o cuidado de verificar se os pacientes não apresentavam alergia à soja, antes de oferecer as bebidas à base de soja. Todos os pacientes que utilizaram bebidas à base de soja já faziam uso desta proteína em suas dietas sem apresentar sintomatologia e também foram anteriormente submetidos à pesquisa de lgE específica a esta proteína através do Prick test.

Os veículos propostos por WILLIAM \& BOCK (1999) para mascarar o LV são a fórmula elementar (Neocate®) ou suco de uva,que possuem sabor marcantes.

"Alguns alimentos têm seu sabor e odor diminuídos quando são apresentados na temperatura mais baixa" (HUIJBERS et al.,1994). Neste estudo, exceto a sopa, as porções foram propositalmente servidas em temperatura mais baixa que a ambiente.

Para o preparo das porções da fase cega placebo, utilizou-se água adicionada ao veículo.

\subsubsection{Esquema para a administração do TPODCPC}

Os testes foram idealizados com base em relatos anteriores da literatura científica (quadro 1), principalmente principalmente na descrição feita por WILLIAM \& BOCK, 1999. 
Quadro 1- Adaptação realizada para o TPODCPC em relação às referências de literatura

\begin{tabular}{|c|c|c|}
\hline DOSE INICIAL DE LV & $\begin{array}{l}5 \mathrm{~mL} \\
1 \mathrm{~mL} \text { (casos com risco de } \\
\text { reação grave) }\end{array}$ & WILLIAMS \& BOCK, 1999 \\
\hline DOSE FINAL DE LV & $25 \mathrm{~mL}$ & $\begin{array}{l}\text { WILLIAMS \& BOCK, } 1999 \\
\text { SICHERER , } 2000\end{array}$ \\
\hline VOLUME TOTAL DE LV & 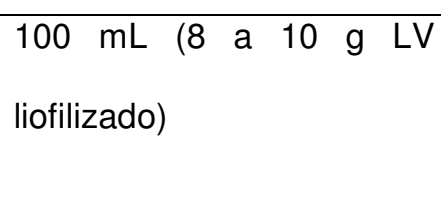 & $\begin{array}{l}\text { BOCK, 1988; WILLIAMS \& } \\
\text { BOCK, } 1999 \\
\text { SICHERER , } 2000\end{array}$ \\
\hline № DE DOSES POR FASE & 6 & $\begin{array}{l}\text { WILLIAMS \& BOCK, } 1999 \\
\text { SICHERER , } 2000\end{array}$ \\
\hline $\begin{array}{l}\text { INTERVALO ENTRE AS } \\
\text { DOSES }\end{array}$ & 15 a 30 minutos & $\begin{array}{l}\text { SICHERER,2000; } \\
\text { NIGGEMANN , } 2007\end{array}$ \\
\hline INTERVALO ENTRE AS FASES & 2 horas & WILLIAMS \& BOCK, 1999 \\
\hline $\begin{array}{l}\text { PROVOCAÇÃO ABERTA } \\
\text { APÓS TESTE NEGATIVO OU } \\
\text { COM RESULTADO DUVIDOSO }\end{array}$ & $\begin{array}{l}200 \mathrm{~mL} \text { de LV em dose } \\
\text { única }\end{array}$ & $\begin{array}{l}\text { WILLIAMS \& BOCK, } 1999 \\
\text { SICHERER,2000 }\end{array}$ \\
\hline
\end{tabular}

\subsubsection{Orientações Pré-teste:}

Foi idealizado um impresso com orientações Pré-teste (Quadro 2) aos pacientes com indicação para a realização do TPODCPC, baseadas nas refrências citadas no quadro abaixo. 
Quadro 2 - Orientações Pré-teste

\begin{tabular}{|l|l|}
\hline Exclusão dietética e de medicamentos & Período antes do exame \\
\hline Dieta isenta de proteína de LV & $\begin{array}{l}2 \text { semanas (MAY, 1976; WILLIAMS \& } \\
\text { BOCK, 1999; CAFFARELLI \& } \\
\text { PETROCCIONE, 2001) }\end{array}$ \\
\hline Anti-histamínicos & 10 dias (BOCK et al., 1988) \\
\hline Corticosteróides sistêmicos & 1 mês \\
\hline Qualquer medicamento * & 12 horas \\
\hline Jejum & 10 horas (BAHNA, 1995) \\
\hline \multicolumn{1}{|c|}{ * }
\end{tabular}

que não interfira na interpretação do teste.

Os familiares receberam requisições de exames que deveriam ser colhidos antes do início do teste, orientações sobre o procedimento e a necessidade da manutenção de acesso venoso durante 0 teste $\mathrm{e}$ orientações fornecidas pela nutricionista: escolha do veículo adequado para cada criança, exclusão total de proteínas de LV, dieta sem corantes e conservantes durante a semana que precede o exame e recordatório alimentar para ser preenchido na semana anterior e posterior ao teste. No dia anterior ao teste, os responsáveis pelos pacientes foram orientados a telefonar para o médico pesquisador: nestas ocasiões, as orientações fornecidas foram checadas e os pacientes sem condições técnicas ou de saúde para a realização do exame foram dispensados. Caso o paciente não entrasse em contato, o pesquisador o fazia.

Foi idealizado também um impresso denominado Check list para ser preenchido pelo médico responsável pelo teste antes de iniciar o exame 
(Anexo A). Este impresso baseou-se no Check list proposto por WILLIAMS \&

BOCK, 1999 com algumas modificações (quadro 3).

\section{Quadro 3- Orientações Pré teste: Modificações no Check list}

\begin{tabular}{|c|c|}
\hline Proposto por WILLIAMS \& BOCK, 1999 & MODIFICAÇÕES \\
\hline $\begin{array}{l}\text { 1. Dieta isenta de proteína de LV por duas } \\
\text { semanas ou mais? }\end{array}$ & Mantida \\
\hline $\begin{array}{l}\text { 2. Anti-histamínicos suspenso por tempo } \\
\text { suficiente para permitir Prick test positivo para } \\
\text { histamina? }\end{array}$ & Dez dias antes \\
\hline $\begin{array}{l}\text { 3. Broncodilatadores, cromoglicatos, } \\
\text { nedocromil e esteróides inalatórios foram } \\
\text { evitados nas úlitimas } 6 \text { a } 12 \text { horas? }\end{array}$ & 12 horas \\
\hline $\begin{array}{l}\text { 4. Equipamentos para tratar anafilaxia } \\
\text { disponíveis? }\end{array}$ & Mantida \\
\hline $\begin{array}{l}\text { 5. Paciente em jejum } 2 \text { a } 3 \text { horas antes do } \\
\text { exame? }\end{array}$ & Pelo menos 10 horas \\
\hline $\begin{array}{l}\text { 6. Primeira dose calculada para ser menor que } \\
\text { a dose responsável por desencadear reação } \\
\text { de acordo com a história? (máximo } 400 \mathrm{mg} \text { ) }\end{array}$ & $\begin{array}{l}\text { Dose inicial }=400 \mathrm{mg}(5 \mathrm{~mL} \text { de } \mathrm{LV}) \\
\text { Anafilaxia anterior }- \text { dose inicial }=1 \mathrm{~mL} \mathrm{LV} \\
\text { Preconizado mas excluído do Check list }\end{array}$ \\
\hline $\begin{array}{l}\text { 7. Dose total de } 8 \text { a } 10 \mathrm{~g} \text { do alimento } \\
\text { liofilizado? } \\
\text { (100 Ml de LV) }\end{array}$ & Mantida \\
\hline $\begin{array}{l}\text { 8. Paciente será observado por } 2 \text { horas após o } \\
\text { término do teste. }\end{array}$ & Mantida \\
\hline
\end{tabular}


Foram acrescentados os seguintes itens ao check list:

- Corticosteróides sistêmicos foram evitados no úlitimo mês? Corticosteróides tópicos de alta potência foram evitados?

- Qualquer medicamento foi evitado nas últimas 12 horas ?

- Termo de Consentimento assinado?

- Acompanhante maior que 18 anos de idade?

- Acesso venoso disponível?

\subsubsection{Avaliação Clínica:}

A avaliação clínica foi realizada através de uma anamnese minuciosa. Dados referentes a fatores de risco para AA foram investigados como: atopia familiar e pessoal. Dados em relação à alergia alimentar foram obtidos como volume desencadeante, intervalo de tempo entre a ingestão e o aparecimento dos sintomas, manifestações clínicas apresentadas, intervalo de tempo desde a última reação, medicamentos utilizados. O exame físico foi realizado em todos os pacientes antes do início dos testes e foram obtidos os sinais vitais (anexo B).

\subsubsection{Avaliação Laboratorial:}

Os pacientes foram submetidos aos seguintes exames laboratoriais antes da realização do TPODCPC: contagem de eosinófilos séricos (número absoluto e percentual), dosagem da concentração sérica de lgE sérica total, concentração da IgE específica para o LV e frações (ImmunoCAP ${ }^{\circledR}$ e/ou Prick test). 
O Prick test foi realizado por médico habilitado segundo a técnica modificada de PEPYS (1975), utilizando materiais padronizados como lancetas de plástico descartáveis e individuais para cada extrato, incluindo LV e frações: a-lactoalbumina, $\beta$-lactoglobulina e caseína da IPIASAC,ESPANHA. Também foram realizados testes com extrato para soja e LV in natura. O teste foi realizado no antebraço da criança com a aplicação de gotas dos extratos e dos controles: negativo (diluente) e positivo (histamina $1 \mathrm{mg} / \mathrm{mL}$ ), observando-se a distância mínima de $3 \mathrm{~cm}$ entre cada extrato. Os resultados foram lidos após 15 minutos da aplicação dos extratos. O critério de positividade adotado foi o mesmo utilizado por WILLIAM \& BOCK (1999), considerando positivos os resultados cujas medidas de pápulas foram maiores ou iguais a $3 \mathrm{~mm}$ em relação ao controle negativo.

O ImmunoCAP ${ }^{\circledR}$ (Pharmacia Diagnostics; Uppsala, Sweden) foi realizado conforme metodologia detalhada pelo fornecedor (Axen et al., 1988) para o LV e suas frações ( $\alpha$-lactoalbumina, $\beta$-lactoglobulina e caseína). O critério de positividade baseou-se no descrito em SAMPSON \& ALBERGO (1984) que considera resultado positivo aquele cuja classe de RAST sejam maior ou igual a classe III, ou seja, maior ou igual a 3,5 kU/L. Portanto neste estudo, as concentrações de ImmunoCAP ${ }^{\circledR}$ maiores ou iguais a $3,5 \mathrm{kU} / \mathrm{L}$ foram consideradas positivas. 


\subsection{Fase de execucão dos testes:}

Os TPODCPC foram realizados conforme o esquema descrito a seguir:

Fases do TPODCPC: O TPODCPC apresenta duas fases cegas e uma fase aberta:

Fase cega LV: fase cega com LV

Fase cega PLACEBO: fase cega com placebo

Fase ABERTA: fase com o dobro de LV que a fase cega

\subsubsection{Randomização das fases:}

A nutricionista responsável pelo preparo do teste também foi a responsável pela randomização da seqüência das fases cegas. Todas as porções foram identificadas conforme a randomização (período da manhã ou da tarde). Tanto o médico avaliador e a equipe de enfermagem, quanto o paciente e o responsável desconheciam o que estava sendo oferecido junto ao veículo. Somente após o término das duas fases cegas, a seqüência era revelada. A administração do teste seguiu o esquema descrito na tabela 4. 
Tabela 4 - Administração de LV ou placebo (conforme randomização)

\begin{tabular}{lcc}
\hline Volume total/dose * $^{*}$ & LV ou Placebo** & Intervalo (minutos) \\
\hline 1 $^{\text {a }}$ DOSE $60 \mathrm{~mL}$ & $5 \mathrm{~mL}$ & 15 a 30 \\
$2^{\text {a }}$ DOSE $60 \mathrm{~mL}$ & $10 \mathrm{~mL}$ & 15 a 30 \\
$3^{\text {a }}$ DOSE $60 \mathrm{~mL}$ & $15 \mathrm{~mL}$ & 15 a 30 \\
$4^{\text {a }}$ DOSE $60 \mathrm{~mL}$ & $20 \mathrm{~mL}$ & 15 a 30 \\
$5^{\text {a }}$ DOSE $60 \mathrm{~mL}$ & $25 \mathrm{~mL}$ & 15 a 30 \\
6 $^{\text {a DOSE } 60 \mathrm{~mL}}$ & $25 \mathrm{~mL}$ & 15 a 30 \\
\hline
\end{tabular}

*O volume total da amostra foi sempre o mesmo, ou seja: VEÍCULO + LEITE ou PLACEBO = $60 \mathrm{~mL}$ !**Volume total de LV ou placebo $=\mathbf{1 0 0} \mathrm{mL}$

2.2.2 Intervalo após a $1^{\mathrm{a}}$ fase cega: 2 horas

Neste intervalo, os pacientes receberam uma refeição leve, hipoalergênica: arroz, frango cozido, brócolis, cenoura, abobrinha ou chuchu refogados, suco de limão. Sobremesa: gelatina de limão (gelatina incolor e suco de limão) ou fruta (exceto banana por conter histamina, laranja e mamão por serem frutas com tendência laxante, goiabada e bananada devido à alta concentração de acúcar). Os acompanhantes receberam também uma refeição semelhante à do paciente.

2.2.3 Fase aberta: nesta fase, o alimento a ser testado é oferecido de forma aberta e em quantidade duas vezes maior que a oferecida na fase cega. Nos casos em que não nenhuma reação significante tenha ocorrido durante as fases cegas, os pacientes foram submetidos à provocação oral aberta, ou 
seja, receberam $200 \mathrm{~mL}$ de LV. Após o encerramento desta fase, os pacientes permaneceram em observação na enfermaria por pelo menos 1 hora.

Os pacientes foram orientados também a manter a dieta orientada pela nutricionista por mais 7 dias.

\subsubsection{Interpretação do exame:}

Em relação à interpretação dos testes, foram considerados positivos os testes cujos sintomas reproduziram, de forma parcial ou integral, a história clínica do paciente. Alguns sintomas foram considerados significantes ou objetivos na interpretação dos exames: presença de urticária, angioedema, broncoespasmo, estridor laríngeo, coriza, espirros, obstrução nasal, hiperemia conjuntival, lacrimejamento e diarréia. O aparecimento de qualquer um destes sintomas justificou a interrupção do exame e o uso de medicamentos, se necessário. Tais exames foram considerados então positivos. Outros sintomas foram considerados subjetivos ou não observáveis (basearam-se nos relatos dos pacientes) como por exemplo: prurido sem lesão de pele aparente, dor abdominal e náusea (BOCK \& ATKINS, 1990). A presença dos sintomas subjetivos e de pápulas periorais isoladas não justificaram a interrupção dos testes (SICHERER et al., 1999, WILLIAMS \& BOCK ,1999).

Quando os sintomas subjetivos ou a presença de pápulas periorais não estiveram presentes na fase placebo e voltaram a se repetir na fase aberta do teste, o TPODCPC foi considerado positivo. 
Nos casos de anafilaxia, a epinefrina intra-muscular, na região do músculo vasto-lateral da coxa, foi a droga inicial de escolha (SIMONS, 2004). Anti-histamínicos, corticosteróides, broncodilatadores também foram administrados. Nos casos de choque, fluidos intravenosos poderiam ser utilizados (SAMPSON et al.,2006; MURARO et al., 2007). Nos casos em que a melhora do paciente não ocorrer, apesar da medicação administrada, a lavagem gástrica poderá ser indicada para remover todo o alimento ingerido (BOCK et al.,1988).

\subsubsection{Orientações pós teste:}

No momento da alta, os responsáveis pelos pacientes receberam as seguintes orientações por escrito:

- Manter dieta sem proteína do LV

- Comunicar ao médico pesquisador, via telefone, todo e qualquer sintoma apresentado nos dias seguintes ao teste. Se o responsável pelo paciente não entrar em contato, o médico deverá telefonar para obter informações sobre o estado de saúde do paciente após o teste

- Não utilizar medicamentos antes de contactar o médico pesquisador

- Continuar a anotar o recordatório alimentar

- Retornar para consulta médica em 7 dias 


\subsection{Descricão dos dados obtidos no desenvolvimento do TPODCPC adaptado}

\subsubsection{Análise Estatística}

Foram realizadas análises dos dados clínico-epidemiológicos, resultados dos exames laboratoriais (contagem de eosinófilos séricos, dosagem da IgE sérica total, pesquisa da IgE específica para o LV e frações (ImmunoCAP ${ }^{\circledR}$ e Prick test) e dos resultados dos TPODCPC.

Para a análise descritiva dos dados, as variáveis nominais tais como: história familiar e pessoal de atopia foram descritas em freqüência e intervalo de confiança sendo comparadas entre os grupos 1 e 2 pelo teste exato de Fisher utilizando-se o pacote estatístico SPSS versão 13.0.

As variáveis contínuas, tais como os exames laboratoriais (eosinofilia, dosagem dos níveis de lgE total, Prick test e ImunoCAP®) dos grupos 1 e 2 foram descritos através das medianas através do teste de Mann-Whitney.

O nível de significância foi de $5 \%$ em todos os testes estatísticos.

\section{ASPECTOS ÉTICOS}

O projeto deste estudo foi apresentado à Comissão de Ética e Pesquisa do Instituto da Criança do HCFMUSP e á Comissão de Ética para Análise de Projetos de Pesquisa (CAPPesq) do HCFMUSP e foi aprovado sob o número 325/ 02 (Anexo C). 
Os responsáveis pelos pacientes foram informados de forma compreensível sobre o estudo, métodos e necessidade de exames laboratoriais (coleta de sangue e testes cutâneos padronizados), sendo o paciente incluído no estudo apenas após a concordância com os termos de consentimento livre e esclarecido, por escrito, dos pais ou responsável, de acordo com as normas do Comitê de Pesquisa e Ética desta instituição (Anexo D). Antes da assinatura do termo de consentimento livre e esclarecido, houve uma descrição detalhada do teste e da possibilidade de ocorrer reações graves incluindo anafilaxia. O responsável pelo paciente foi informado de que um pronto tratamento estaria disponível e que, devido ao fato do teste ser administrado de modo gradual, poderia ser interrompido se necessário. 
Resultados 


\section{RESULTADOS}

Neste estudo, foram realizados testes em sete pacientes com história pregressa de reação anafilática devido à ingestão de proteínas do LV, porém sem reações graves há mais de 2 anos antes do teste e nenhum paciente apresentava asma não controlada.

Os resultados serão apresentados de acordo com a seguinte divisão:

1. Resultados da fase experimental

2. Dados relacionados à execução do TPODCPC

3. Descrição dos dados obtidos no desenvolvimento do TPODCPC adaptado

\section{Resultados da fase experimental}

\subsection{A escolha do local para a realização do exame}

Os primeiros dois exames foram realizados no Instituto da Criança do HCFMUSP em uma sala de procedimentos próxima aos ambulatórios. Esta sala estava equipada com materiais para o atendimento de reações graves. Durante a realização dos primeiros exames, observou-se a necessidade de um local mais próximo a uma copa e com menor circulação de pessoas. Por este motivo, os exames seguintes foram transferidos para o Hospital Dia da mesma instituição. O Hospital Dia possui um ambiente mais adequado para a realização dos exames, pois devido ao número restrito de leitos, apresenta menor circulação de pessoas e possui uma copa próxima à enfermaria. 
Os exames transcorreram de forma tranqüila apesar de sua duração prolongada: cerca de 7 a 9 horas. A existência de poltronas confortáveis para acomodar o acompanhante bem como a disponibilidade de material lúdico como brinquedos, livros, revistas e televisão contribuíram para este fato.

O Hospital Dia do Instituto da Criança HCFMUSP estava equipado com materiais e equipe multiprofissional capacitada para o atendimento de reações graves e coleta de exames laboratoriais. O local escolhido apresentou condições para permitir uma adequada interpretação dos resultados dos testes: boas condições de temperatura, ventilação, iluminação e ausência de fatores "irritantes", como por exemplo: ruídos e odores (figura 1).

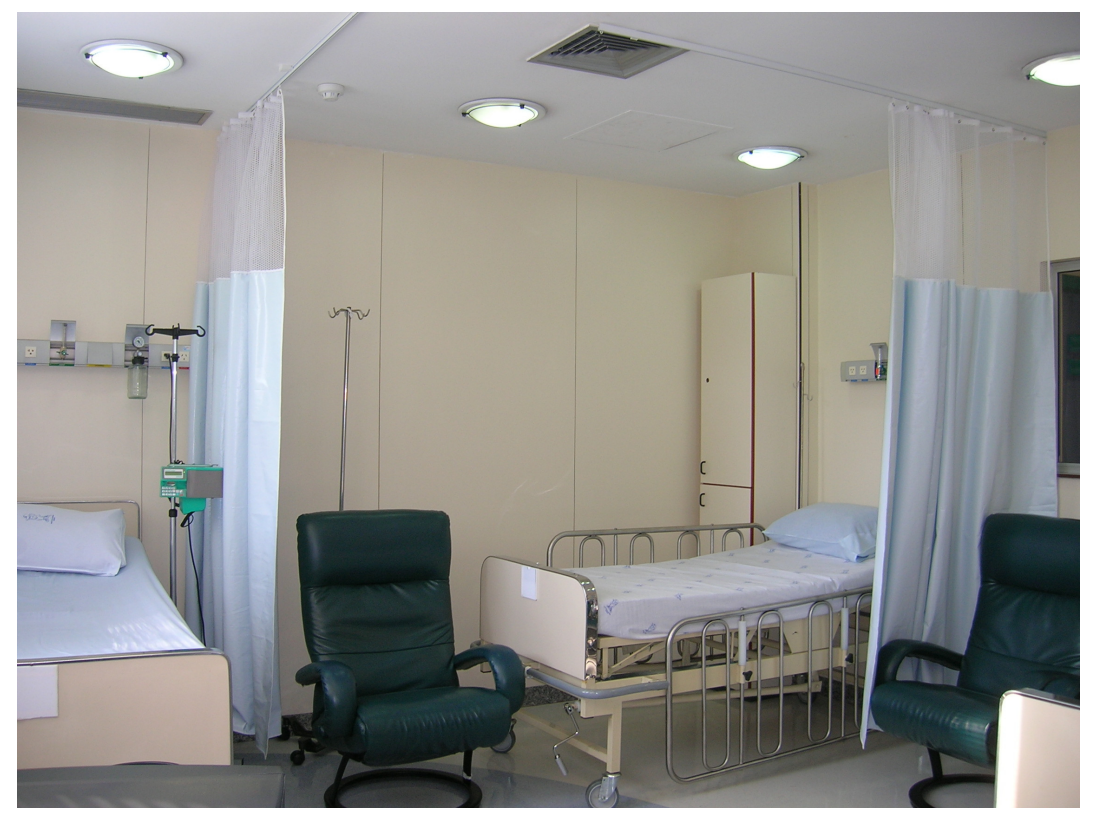

Figura 1: Foto da enfermaria do Hospital Dia do Instituto da Criança do HCFMUSP 
A copa do Hospital Dia possuía os equipamentos necessários para o preparo das porções do teste, bem como para a conservação destes (figura 2). A localização da copa próxima às enfermarias também foi importante para facilitar o transporte das porções.

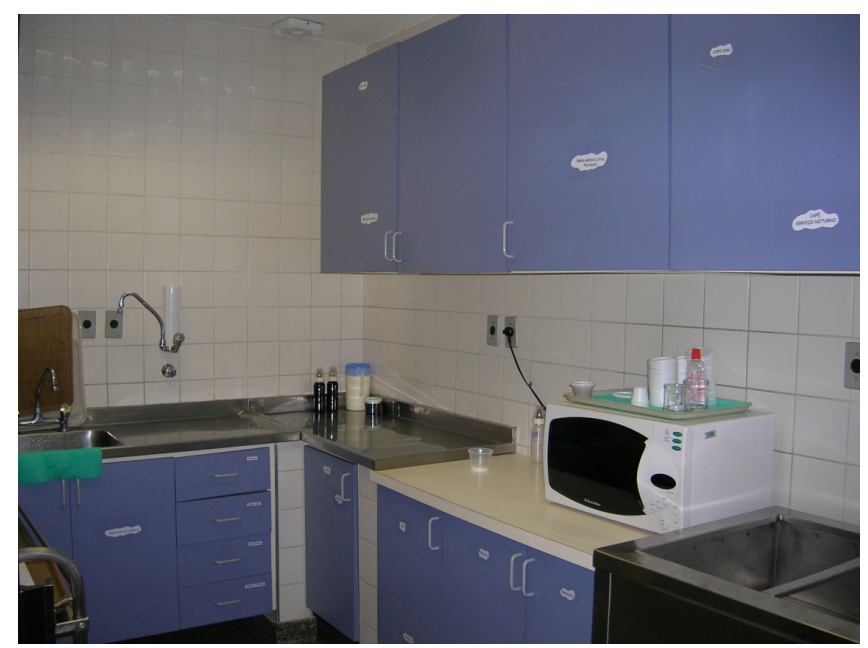

Figura 2: Foto da copa do Hospital Dia do Instituto da Criança do HCMFUSP

\subsection{A escolha dos veículos}

Inicialmente foi oferecido um manjar como veículo, composto por leite de côco, gelatina incolor, açúcar e baunilha. Porém, sua utilização foi tentada sem sucesso, pois o paciente recusou todas as porções oferecidas,

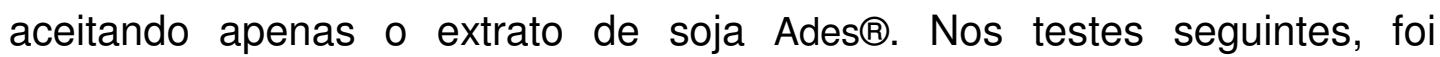
oferecido suco de maçã (Yakult@) como veículo. Por este motivo, no decorrer do estudo, houve a necessidade de aumentar as opções de veículos. Tais opções eram oferecidas para que a mãe ou o responsável pelo paciente pudessem escolher entre as várias preparações disponíveis, de acordo com o preferência da criança (tabela 4). Passou-se a utilizar a 
sopa de legumes que foi empregada em 11 exames. Esta preparação apresentou a capacidade de mascarar o leite, porém sua aceitação foi parcial em três pacientes e houve recusa em um. A sopa apresenta um preparo laborioso e o ideal é que seja confeccionada no mesmo dia do teste. O mesmo pode ser afirmado em relação ao preparo do manjar, que posteriormente foi retirado da opção de veículos.

Os sucos comercializados em embalagens tipo longa vida (Tetra Pak®) passaram a ser oferecidos como opções de veículos devido à praticidade no transporte, conservação e preparo. Foram realizados testes com suco de maçã da Yakult® (dois exames) e suco de uva da Maguary® e Del Valle ${ }^{\circledR}$ (uma vez cada), com boa aceitação. Durante a execução dos exames, notou-se que os veículos oferecidos na apresentação líquida eram melhores e rapidamente aceitos, em comparação com a sopa. No entanto, percebeu-se que não mascararam completamente a cor do leite.

O suco de laranja natural foi utilizado como alternativa, após várias tentativas em oferecer a sopa a um paciente.

A bebida à base de soja $\left(\right.$ Tonyu $\left.^{\circledR}\right)$ foi o veículo mais utilizado (45 exames). Os sabores morango e maracujá foram utilizados de forma alternada no mesmo exame, para melhor aceitação da preparação, por 36 pacientes. Houve boa aceitação por 34 pacientes e parcial por dois. Isto foi realizado em virtude dos pacientes frequentemente recusarem a preparação de mesmo sabor. Foi utilizado somente o sabor maracujá em quatro exames (uma aceitação parcial) e o sabor morango em um paciente, com boa aceitação. Em determinadas ocasiões, houve dificuldade em encontrar os 
sabores morango e maracujá. Nestes casos, optou-se pela substituição do sabor em falta, pelos sabores abacaxi ou maçã da mesma marca. O sabor maçã teve boa aceitação em três exames e parcial em um. Neste último foi utilizado também o sabor abacaxi. A aceitação de todos os veículos testados estão descritas na tabela 5).

As características que fizeram com que a bebida à base de soja Tonyu® (figura 3) fosse frequentemente escolhida são descritas abaixo:

1- Capacidade de mascarar o sabor, odor e o aspecto do leite, mantendo um sabor agradável mesmo em volume pequeno.

2- Possibilidade de alternar sabores diferentes para melhorar a aceitação das porções. Na maioria dos testes, foram utilizados os sabores morango e maracujá alternadamente. Na falta destes, foram utilizados os sabores maçã ou abacaxi.

3- Este produto é facilmente encontrado em supermercados, tem um preço acessível e sua embalagem permite ter validade longa enquanto fechado, podendo ser estocado.

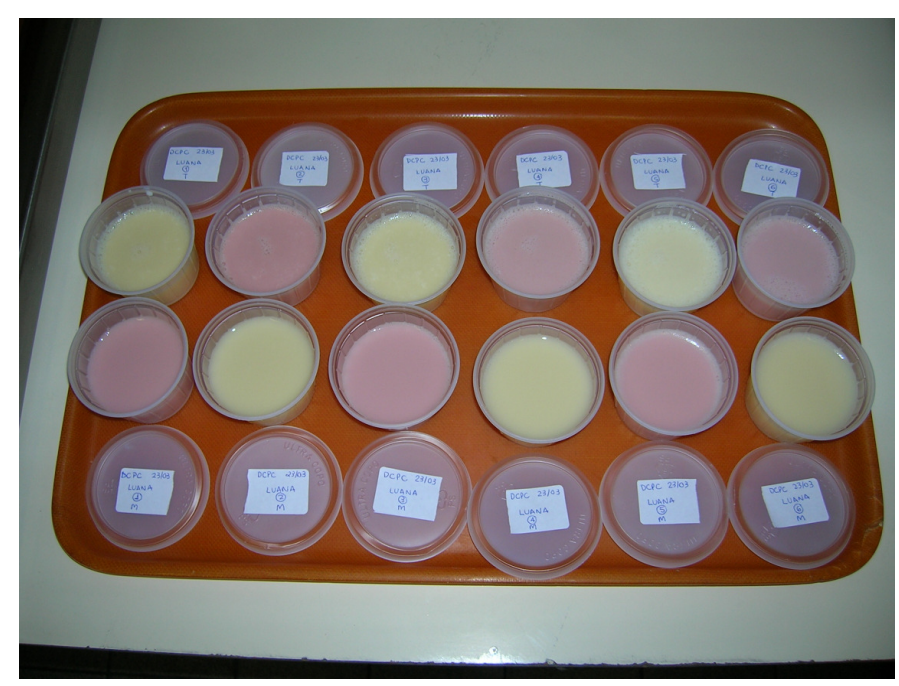

Figura 3- Foto das porções com Tonyu ${ }^{\circledR}$ de morango e maracujá (com placebo e LV) 
Após todas estas etapas, decidiu-se pela escolha da bebida à base de soja da marca Tonyu® sabores morango e maracujá, utilizados de forma alternada, como veículos para a execução do TPODCPC. Aos pacientes que não toleravam proteínas de soja, ofereceu-se a sopa de legumes como opção ou suco de frutas.

Tabela 5 - Aceitação dos veículos utilizados pelos pacientes

\begin{tabular}{|c|c|c|c|}
\hline \multirow[t]{2}{*}{ VEÍCULOS } & \multicolumn{3}{|c|}{ ACEITAÇÃO } \\
\hline & TOTAL & PARCIAL & RECUSA \\
\hline Bebidas à base de soja & 34 & 2 & 0 \\
\hline \multicolumn{4}{|l|}{ de morango e maracujá Tonyu ${ }^{\circledR}$} \\
\hline Sopa de Legumes & 7 & 3 & 1 \\
\hline Bebida à base de soja maracujá Tonyu ${ }^{\circledR}$ & 3 & 1 & 0 \\
\hline Suco de maçã Yakult ${ }^{\circledR}$ & 2 & 0 & 0 \\
\hline Suco de uva Del Valle ${ }^{\circledR}$ e Maguary ${ }^{\circledR}$ & 2 & 0 & 0 \\
\hline Bebida à base de soja morango Tonyu ${ }^{\circledR}$ & 1 & 0 & 0 \\
\hline Extrato de soja Ades ${ }^{\circledR}$ & 1 & 0 & 0 \\
\hline Suco de laranja com acerola $\operatorname{Ades}^{\circledR}$ & 1 & 0 & 0 \\
\hline Suco de laranja natural & 1 & 0 & 0 \\
\hline Bebida à base de soja & 1 & 0 & 0 \\
\hline \multicolumn{4}{|l|}{ de maçã e maracujá Tonyu ${ }^{\circledR}$} \\
\hline Bebidas à base de soja & 0 & 1 & 0 \\
\hline \multicolumn{4}{|l|}{ de Abacaxi, maracujá e maçã Tonyu ${ }^{\circledR}$} \\
\hline Bebidas à base de soja & 2 & 0 & 0 \\
\hline \multicolumn{4}{|l|}{ de morango, maracujá e maçã Tonyu ${ }^{\circledR}$} \\
\hline Manjar & 0 & 0 & 1 \\
\hline
\end{tabular}

Apesar de nenhum veículo testado ter igualado completamente as características entre as porções de LV e de placebo, as pequenas diferenças encontradas foram aceitáveis já que conseguiram mascarar principalmente o sabor do LV. Verificou-se, no decorrer do estudo, a necessidade de 
desenvolver recipientes opacos que pudessem mascarar completamente a cor do LV.

\subsection{Materiais necessários para a realização do TPODCPC}

Para o preparo das porções, utilizou-se seringas descartáveis para medir o volume tanto do LV, quanto do veículo. No entanto, devido à pressão exercida pelo êmbolo, as porções com LV apresentaram-se no início com espuma, principalmente nas doses de $20 \mathrm{~mL}$ e $25 \mathrm{~mL}$. Optou-se por manter o uso da seringa, porém evitando-se a pressão durante a adição do LV ao veículo.

Como rotina, a nutricionista preparava primeiramente as porções do placebo e as armazenava em geladeira. Somente depois, eram confeccionadas as porções com o LV para evitar a contaminação.

\subsubsection{A escolha dos recipientes para a administração das preparações do teste}

Optou-se por utilizar copos com tampa e canudos, todos opacos e descartáveis, servidos apoiados em suportes para copos também coloridos e opacos (figura 4). Com estes materiais, tanto o odor quanto o aspecto das porções, principalmente em relação à cor, foram mascarados. A troca dos copos por mamadeiras foi necessária para algumas crianças menores. Nestes casos, o conteúdo das mamadeiras foi encoberto por papel opaco. 


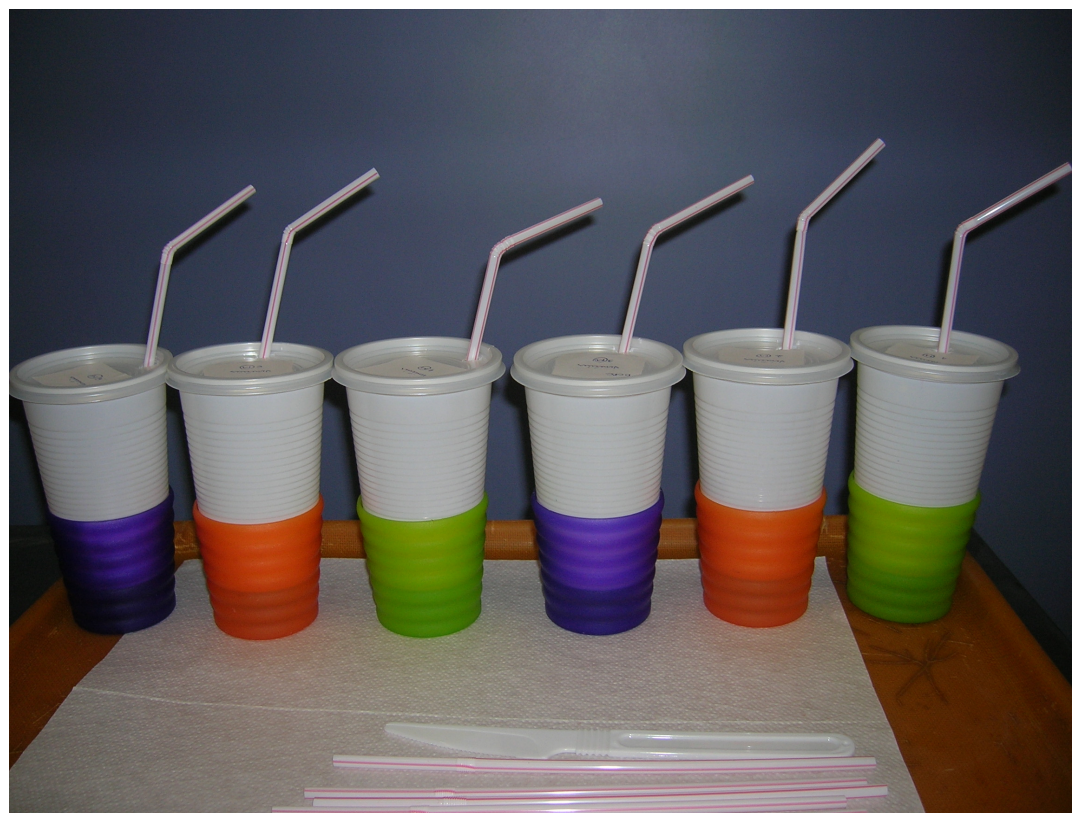

Figura 4- Foto dos recipientes utilizados no TPODCPC

\subsubsection{A escolha da forma de apresentação do leite de vaca para o}

\section{TPODCPC}

Inicialmente, neste estudo, optou-se pelo uso do LV integral em pó reconstituído com adição de água e para a finalização do teste (provocação aberta) foram utilizados achocolatados ou iogurtes de LV. No decorrer do estudo, observou-se que cinco pacientes apresentaram sintomas gastrintestinais durante ou após a fase do teste com LV. Quatro referiram dor abdominal e três apresentaram aumento das evacuações. Este sintoma não era referido na história clínica destes pacientes. Neste momento, foi feita a hipótese de que tal sintoma pudesse ser desencadeado por possível deficiência na produção de lactase, após longo período de tempo com exclusão de lactose na dieta (HEYMAN, 2006). Passou-se então, a utilizar o LV com baixo teor de lactose (da marca Zymil ${ }^{\circledR}$ ), tanto na fase cega LV 
quanto na fase aberta do teste. Esta marca foi escolhida devido à melhor palatabilidade em relação às outras marcas comerciais e por ter um preço acessível.

\subsection{Adaptações no esquema de administração do leite de vaca ou placebo}

O esquema para a administração de LV ou placebo seguiu o descrito por WILLIAMS \& BOCK (1999), com adaptação tanto para aumento do volume por dose como em relação ao intervalo entre cada dose, mantendose o volume final de $100 \mathrm{~mL}$, conforme demonstrado na tabela 6 .

Tabela 6. Esquema de administração de LV ou placebo modificado de WILLIAMS \& BOCK, 1999

\begin{tabular}{|c|c|c|c|}
\hline \multicolumn{2}{|c|}{ Volume de LV ou Placebo* } & \multicolumn{2}{|c|}{ Intervalo (minutos) } \\
\hline $\begin{array}{c}\text { WILLIAMS \& BOCK } \\
1999\end{array}$ & Adaptado & $\begin{array}{c}\text { WILLIAMS \& BOCK } \\
1999\end{array}$ & Adaptado \\
\hline $1^{\text {a }}$ DOSE $5 \mathrm{~mL}$ & $5 \mathrm{~mL}$ & 10 & 15 a 30 \\
\hline $2^{\mathrm{a}}$ DOSE $10 \mathrm{~mL}$ & $10 \mathrm{~mL}$ & 10 & 15 a 30 \\
\hline $3^{a}$ DOSE $20 \mathrm{~mL}$ & $15 \mathrm{~mL}$ & 10 & 15 a 30 \\
\hline 4믈 DOSE $20 \mathrm{~mL}$ & $20 \mathrm{~mL}$ & 10 & 15 a 30 \\
\hline 5 DOSE $20 \mathrm{ml}$ & $25 \mathrm{~mL}$ & 10 & 15 a 30 \\
\hline 6믈 $25 \mathrm{ml}$ & $25 \mathrm{~mL}$ & 10 & 15 a 30 \\
\hline
\end{tabular}

Volume total de LV ou placebo $=100 \mathrm{~mL}$

A razão para esta adaptação se justifica pelo seguinte motivo: avaliando o esquema proposto por WILLIAMS \& BOCK (1999), observou-se que o aumento da dose do leite era rápida no início do teste. Optou-se pelo 
aumento gradual da dose, mantendo-se o volume total sugerido de $100 \mathrm{~mL}$ de LV ou placebo, ao final da fase cega.

O volume de LV, desencadeante de sintomas, relatado na história clínica do Grupo 1 variou de $1 \mathrm{~mL}$ a $240 \mathrm{~mL}$ (mediana de $10 \mathrm{~mL}$ e média de $41 \mathrm{~mL}$ ). O volume de LV responsável pelo desencadeamento de sintomas durante o TPODCPC variou de $1 \mathrm{~mL}$ a $230 \mathrm{~mL}$ (mediana de $15 \mathrm{~mL}$ e média de $36,1 \mathrm{~mL})$.

Uma paciente do grupo 1 necessitou de uma modificação do esquema proposto. Devido ao medo da paciente de tomar LV, a fase aberta foi substituída pelo teste simples cego ou seja, foi oferecido o LV diluído no veículo sem que a pacientes soubesse.

\section{2- Dados relacionados à execucão do TPODCPC}

\subsection{Dificuldades}

As principais dificuldades encontradas durante a realização dos TPODCPC serão citadas a seguir:

Cancelamento de exames na fase pré-teste: Os principais motivos que levaram ao cancelamento do teste momentos antes do início deste foram: uso de anti-histamínicos não informado anteriormente pelo familiar, presença de sinais ou sintomas que pudessem interferir na interpretação dos resultados tais como febre, diarréia, sintomas respiratórios, exacerbação de comorbidades como asma e rinite. 


\section{Manutenção do acesso venoso durante o TPODCPC}

Nos primeiros seis exames, o acesso venoso era mantido através de scalp heparinizado para permitir melhor mobilidade ao paciente. No entanto, dois pacientes perderam o acesso e não puderam ser medicados por esta via, no momento da reação. Nos exames seguintes, foi recomendado que o acesso fosse mantido com solução fisiológica em gotejamento lento contínuo para melhor monitorização.

\section{Reações relacionadas ao TPODCPC}

Todos os pacientes do grupo 1 (provável APLV apresentaram TPODCPC positivos enquanto todos do grupo 2 ( exclusão de APLV pela história clínica) apresentaram TPODCPC negativos.

Entre os pacientes do Grupo 1, nove completaram as três fases do teste apresentando sintomas apenas nas fases com LV (dois pacientes só apresentaram sintomas na fase aberta com LV). Os pacientes que apresentaram manifestações na fase cega LV necessitaram ser submetidos à fase aberta para confirmação do resultado (sintomas subjetivos ou diferentes da história clínica). Em 16 pacientes, o exame foi interrompido após a realização das duas fases cegas e 14 pacientes apresentaram reprodução dos sintomas da história logo na primeira fase (da manhã) do teste e não realizaram o restante do teste. Todos os pacientes do Grupo 2 foram submetidos às três fases do teste sem manifestações clínicas.

As manifestações clínicas apresentadas durante a realização do TPODCPC pelos pacientes do grupo 1 estão listadas na tabela 7 . 
Tabela 7 - Manifestações clínicas imediatas durante a realização do TPODCPC em 39 pacientes do Grupo1

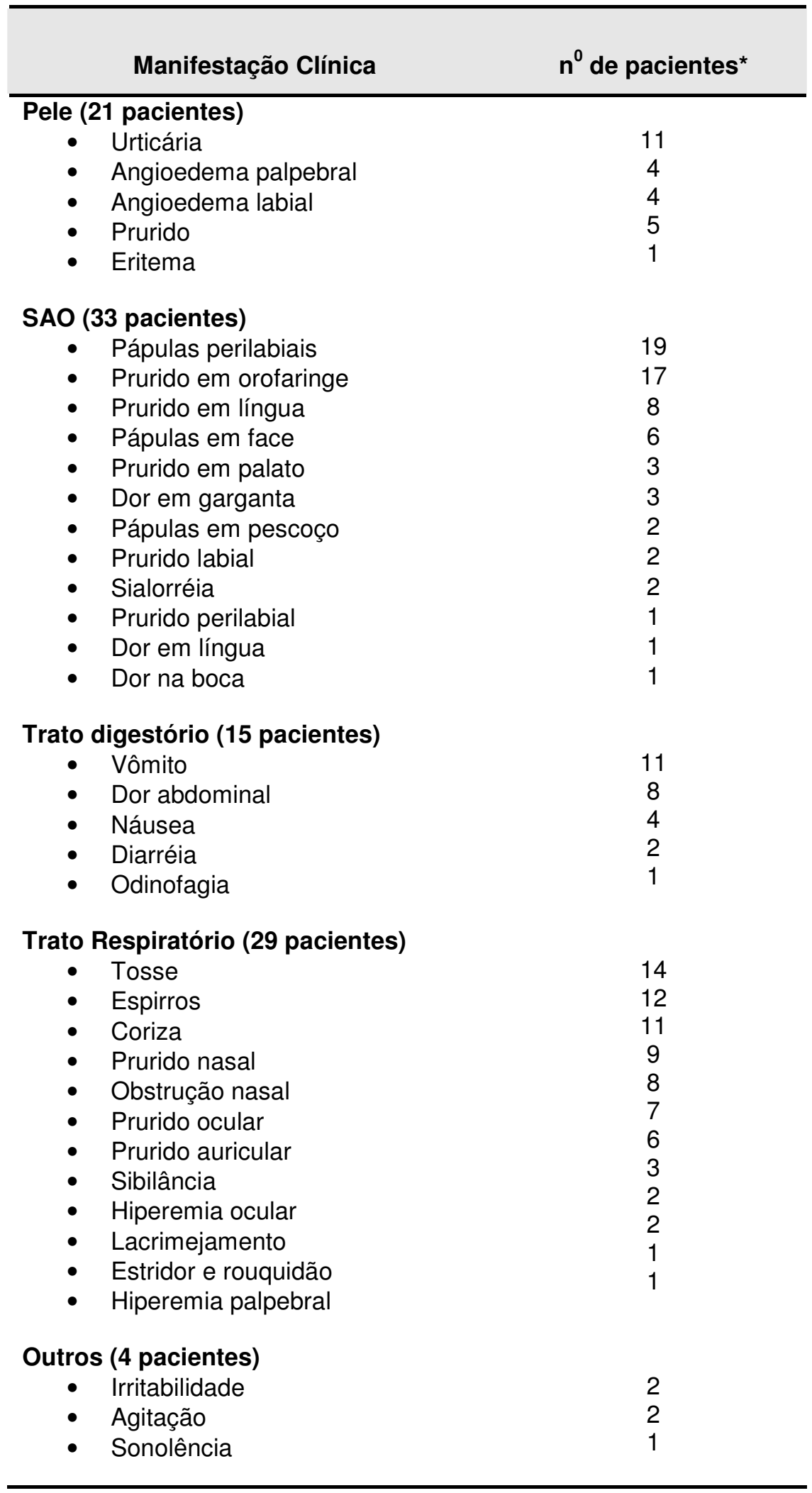

* Alguns pacientes apresentaram mais de uma manifestação 


\section{Reações tardias}

As reações que ocorreram 2 horas ou mais após a última dose do LV foram consideradas como reações tardias. Neste estudo, seis pacientes apresentaram estas reações, além das reações imediatas (tabela 8):

Tabela 8. Descrição das reações tardias em cinco pacientes do grupo 1

\begin{tabular}{cll}
\hline Paciente & Intervalo de tempo & Sintomas \\
\hline 5 & 8 horas & Vômitos \\
33 & 3 horas & Tosse, broncoespasmo, prurido, angioedema \\
35 & 24 horas & Espirros, coriza, diarréia, vômito \\
43 & 24 horas & Diarréia \\
51 & 2 horas e 15 minutos & Hiperemia ocular, eritrodermia em tórax \\
\hline
\end{tabular}

\section{Reações na fase placebo}

Entre os 44 pacientes que realizaram a fase placebo, cinco apresentaram reações nesta fase (tabela 9)

Tabela 9. Reações na fase placebo dos 44 pacientes submetidos ao TPODCPC e que realizaram pelo menos duas fases do teste

\begin{tabular}{ll}
\hline Paciente & Manifestações clínicas $^{*}$ \\
\hline 20 & Diarréia (quatro episódios) \\
31 & Prurido e hiperemia em tórax \\
44 & Hiperemia retroauricular \\
45 & Vômito (um episódio) \\
46 & Prurido e eritrodermia em abdome \\
\hline${ }^{*}$ Todos as manifestações tiveram resolução espontânea
\end{tabular}


Os critérios utilizados para a decisão de interromper os testes foram: necessidade do uso de medicamentos e instabilidade clínica após determinada reação. Os sintomas considerados subjetivos, ou seja, sintomas não observáveis, não foram suficientes para interromper os testes (exceto nos pacientes com história pregressa de reação grave).

\section{Tratamento medicamentoso durante os exames}

O medicamento mais utilizado para tratamento de reações durante o teste foi o anti-histamínico cloridrato de difenidramina por via endovenosa $(n=25)$. A epinefrina intra-muscular foi indicada em cinco pacientes anafiláticos. Quatro pacientes apresentaram: rouquidão, estridor, broncoespasmo associado a urticária ou angioedema. Uma paciente apresentou prurido de orofaringe e sintomas de rinite durante o exame, sendo a epinefrina indicada devido ao seu histórico anterior de anafilaxia. Um paciente, sem história pregressa de reação grave, apresentou urticária acompanhada de broncoespasmo, sintomas estes compatíveis com anafilaxia segundo SAMPSON et al.(2006). Corticosteróides sistêmicos foram necessários em quatro pacientes além de anti-emético Dimenidrinato (Dramin $B 6^{\circledR}$ ) e hidratação endovenosa em um paciente que apresentou vômitos recorrentes. Três pacientes receberam broncodilatador por via inalatória, com boa resposta. Um outro paciente apresentou manifestações cutâneas e broncoespasmo com queda importante do peak flow, não apresentando melhora imediata com as medicações usuais, necessitando lavagem gástrica, conduta esta preconizada por BOCK et al.(1988). 
Interpretação dos exames

De acordo com os critérios para o diagnóstico de anafilaxia sugerida por Sampson et al.(2006) e adaptada no Position Paper da EAACI (MURARO, 2007), as reações foram classificadas, em relação à gravidade, em leves $(n=27)$ e moderadas $(n=3)$. Não houve reação grave de acordo com os critérios sugeridos.

3. Análise descritiva da associacão entre antecedentes de atopia e exames laboratoriais em relação aos resultados do

\section{$\underline{\text { TPODCPC }}$}

Foi encontrada associação estatisticamente significante entre as seguintes variáveis (gráficos 1 a 8):

- TPODCPC e Prick test (frações: LV, $\beta$, caseína e LV in natura)

- $T P O D C P C$ e ImunoCAP ${ }^{\circledR}$ para o LV e todas suas frações

- TPODCPC e a atopia pessoal

As outras variáveis não mostraram associação estatisticamente significante, conforme as tabelas 10 e 11 . 
Tabelas 10- Freqüência de Atopia Familiar e Atopia Pessoal e sua associação com os resultados do TPODCPC

\begin{tabular}{|c|c|c|c|c|}
\hline Variável & & \multicolumn{2}{|c|}{ TPODCPC } & $p$ \\
\hline & & POSITIVO & NEGATIVO & \\
\hline ATOPIA & sim & 28 & 12 & 05 \\
\hline FAMILIAR & não & 11 & 7 & 0,534 \\
\hline ATOPIA & sim & 30 & 9 & רים \\
\hline PESSOAL & não & 9 & 10 & ו \\
\hline
\end{tabular}

Teste exato de Fisher

Tabela 11: Comparação das medianas dos dados laboratoriais com os resultados do TPODCPC

\begin{tabular}{|c|c|c|c|c|c|c|c|}
\hline \multirow[t]{2}{*}{ Variável } & \multicolumn{3}{|c|}{ TPODCPC POSITIVO } & \multicolumn{3}{|c|}{ TPODCPC NEGATIVO } & \multirow[t]{2}{*}{$\mathbf{p}^{*}$} \\
\hline & Máx & Min & med & & Min & med & \\
\hline $\begin{array}{l}\text { Eosinófilos } \\
\left(\mathrm{n} \% / \mathrm{mm}^{3)}\right.\end{array}$ & 1130 & 97 & 387,9 & 918 & 36 & 392 & 0,551 \\
\hline $\begin{array}{l}\text { IgE TOTAL } \\
\text { (Ul/mL) }\end{array}$ & 8000 & 28 & 289 & 4890 & 10 & 159 & 0,145 \\
\hline $\begin{array}{l}\text { PT LV } \\
(\mathrm{mm})\end{array}$ & 20 & 0 & 5 & 6 & 0 & 0 & $<0,001$ \\
\hline $\begin{array}{l}\text { PT ALFA } \\
(\mathrm{mm})\end{array}$ & 15 & 0 & 2 & 5 & 0 & 1 & 0,438 \\
\hline PT BETA (mm) & 25 & 0 & 6,5 & 5 & 0 & 0 & $<0,001$ \\
\hline $\begin{array}{l}\text { PT CASEÍNA } \\
(\mathrm{mm})\end{array}$ & 12 & 0 & 3 & 4 & 0 & 0 & 0,04 \\
\hline $\begin{array}{l}\text { PT LV in natura } \\
(\mathrm{mm})\end{array}$ & 17 & 0 & 8 & 1 & 0 & 0 & $<0,001$ \\
\hline $\begin{array}{l}\text { ImmunoCAP® } \\
\text { LV (kU/L) }\end{array}$ & 59,30 & 0,35 & 3,83 & 5,11 & 0,35 & 0,35 & $<0,001$ \\
\hline $\begin{array}{l}\text { ImmunoCAP® } \\
\text { ALFA (kU/L) }\end{array}$ & 26,20 & 0,35 & 0,77 & 7,58 & 0,35 & 0,35 & 0,001 \\
\hline $\begin{array}{l}\text { ImmunoCAP® } \\
\text { BETA (kU/L) }\end{array}$ & 9,67 & 0,35 & 1,09 & 1,85 & 0,35 & 0,35 & $<0,001$ \\
\hline $\begin{array}{l}\text { ImmunoCAP® } \\
\text { CASEÍNA (kU/L) }\end{array}$ & 47,00 & 0,35 & 1,45 & 2,10 & 0,35 & 0,35 & $<0,001$ \\
\hline
\end{tabular}

Teste de Mann-Whitney 
Gráfico 1: Distribuição das concentrações séricas de lgE específica para leite de vaca nos grupos com TPODCPC negativo e positivo

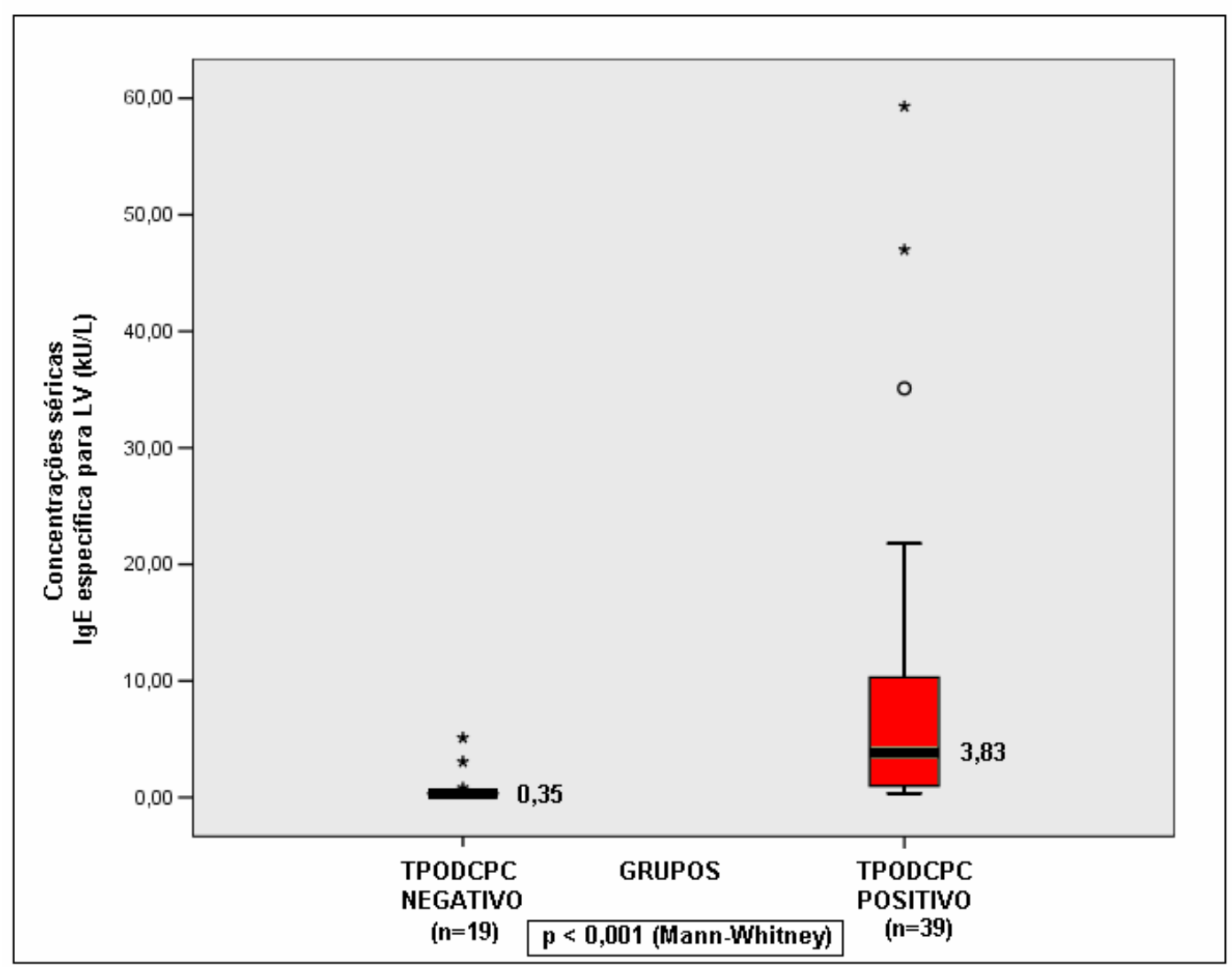


Gráfico 2: Distribuição das concentrações séricas de IgE específica para $\alpha$-lactoalbumina nos grupos com TPODCPC negativo e positivo

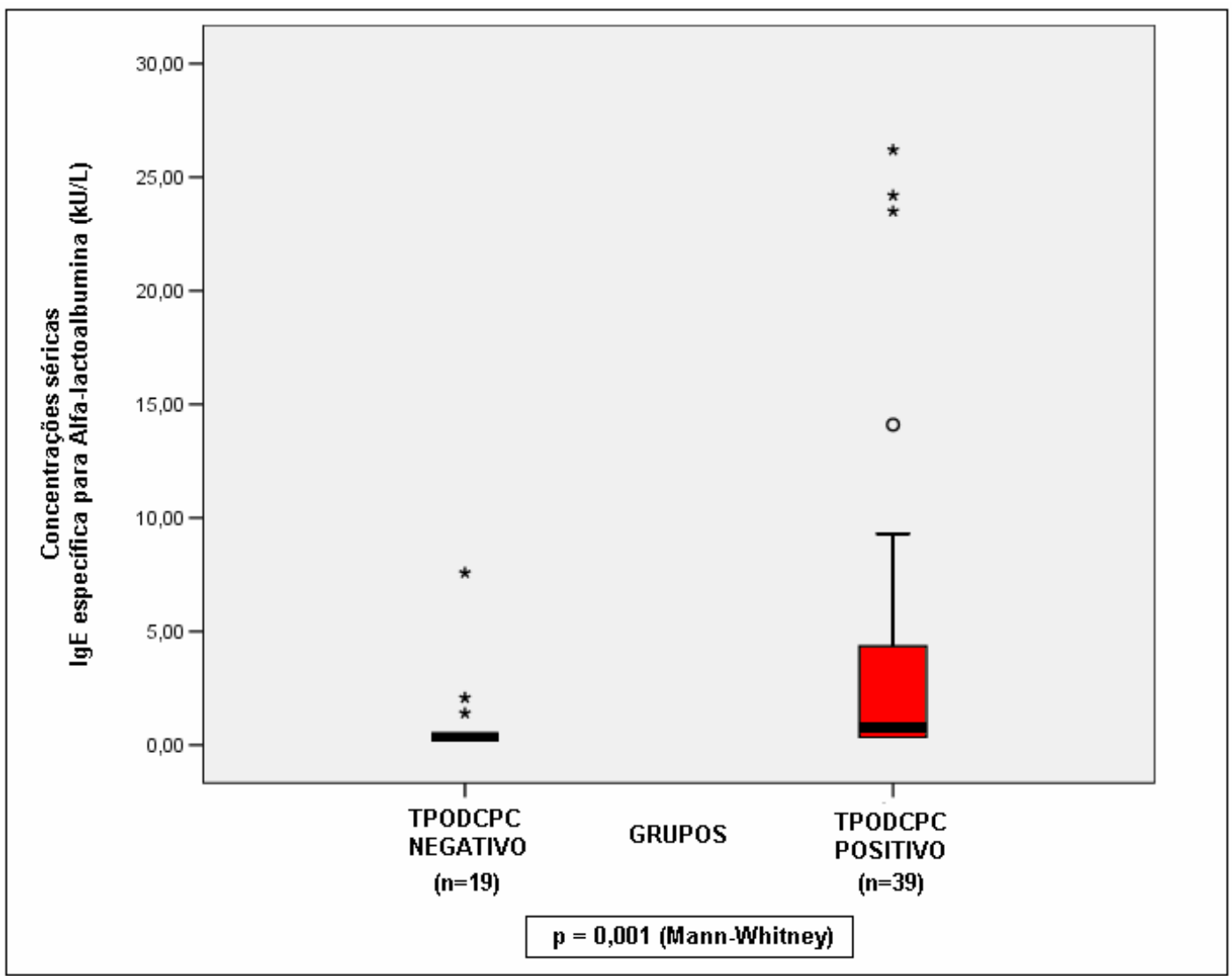


Gráfico 3: Distribuição das concentrações séricas de IgE específica para $\beta$-lactoglobulina nos grupos com TPODCPC negativo e positivo

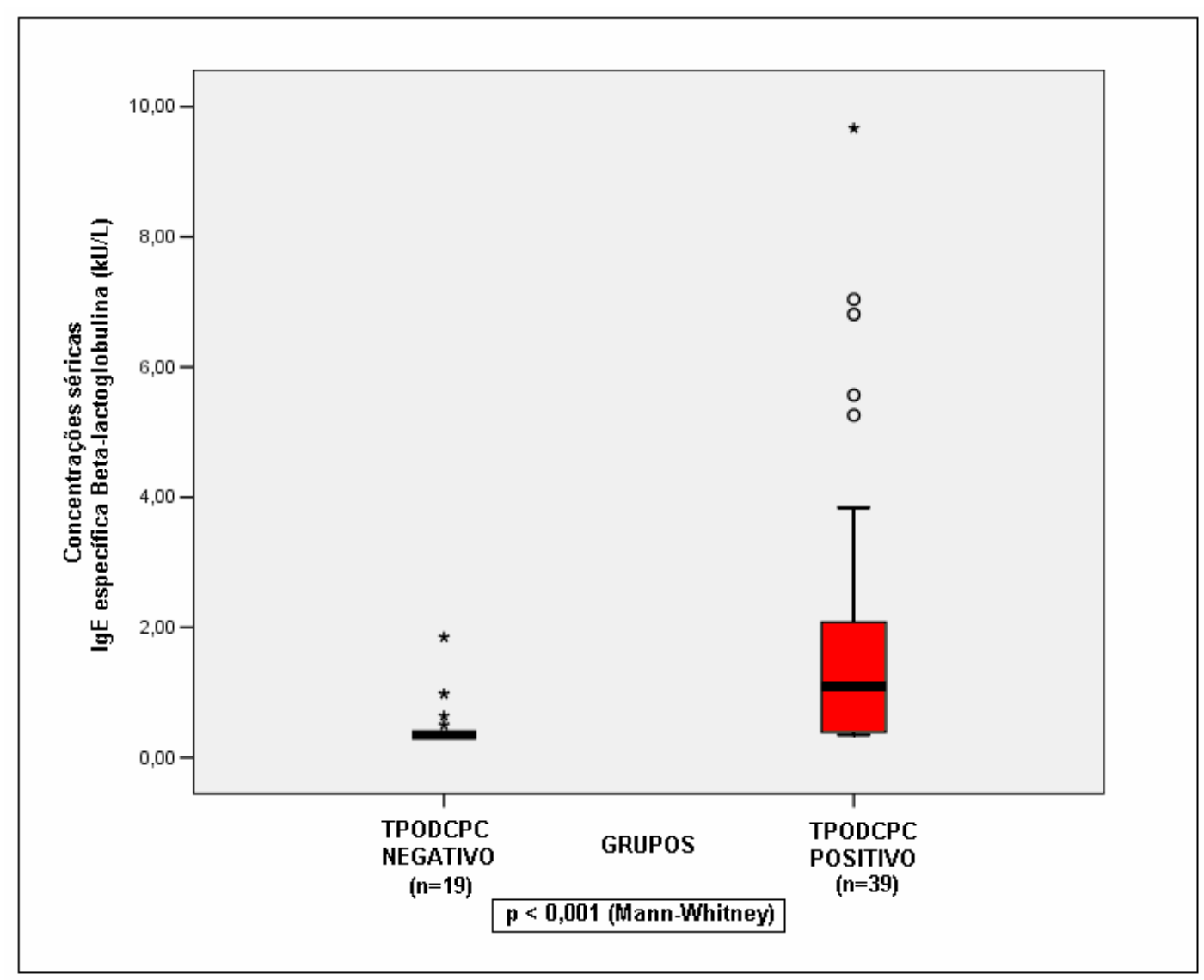


Gráfico 4: Distribuição das concentrações séricas de IgE específica para Caseína nos grupos com TPODCPC negativo e positivo

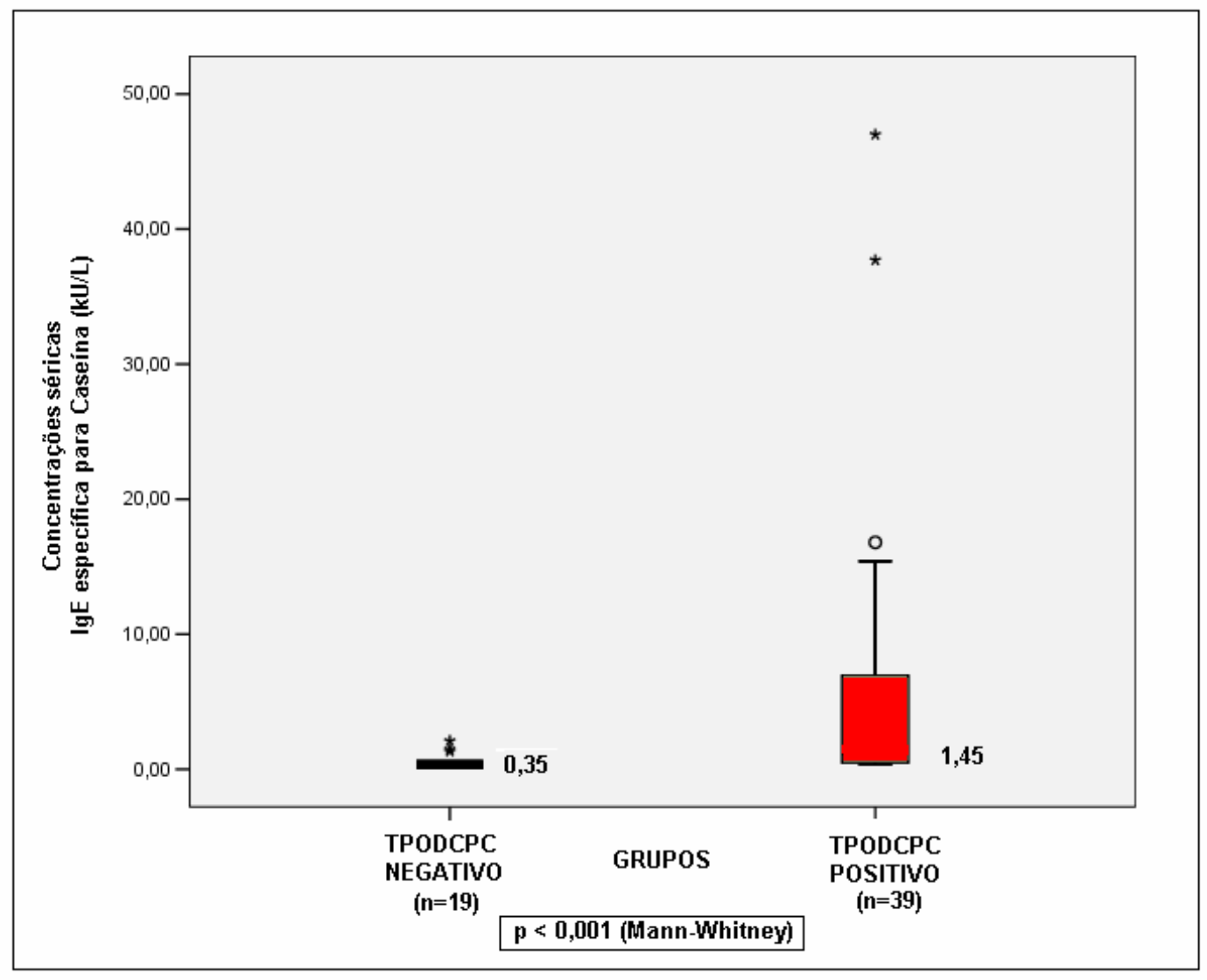


Gráfico 5: Distribuição das medidas da pápula do Prick Test para leite de vaca nos grupos com TPODCPC negativo e positivo

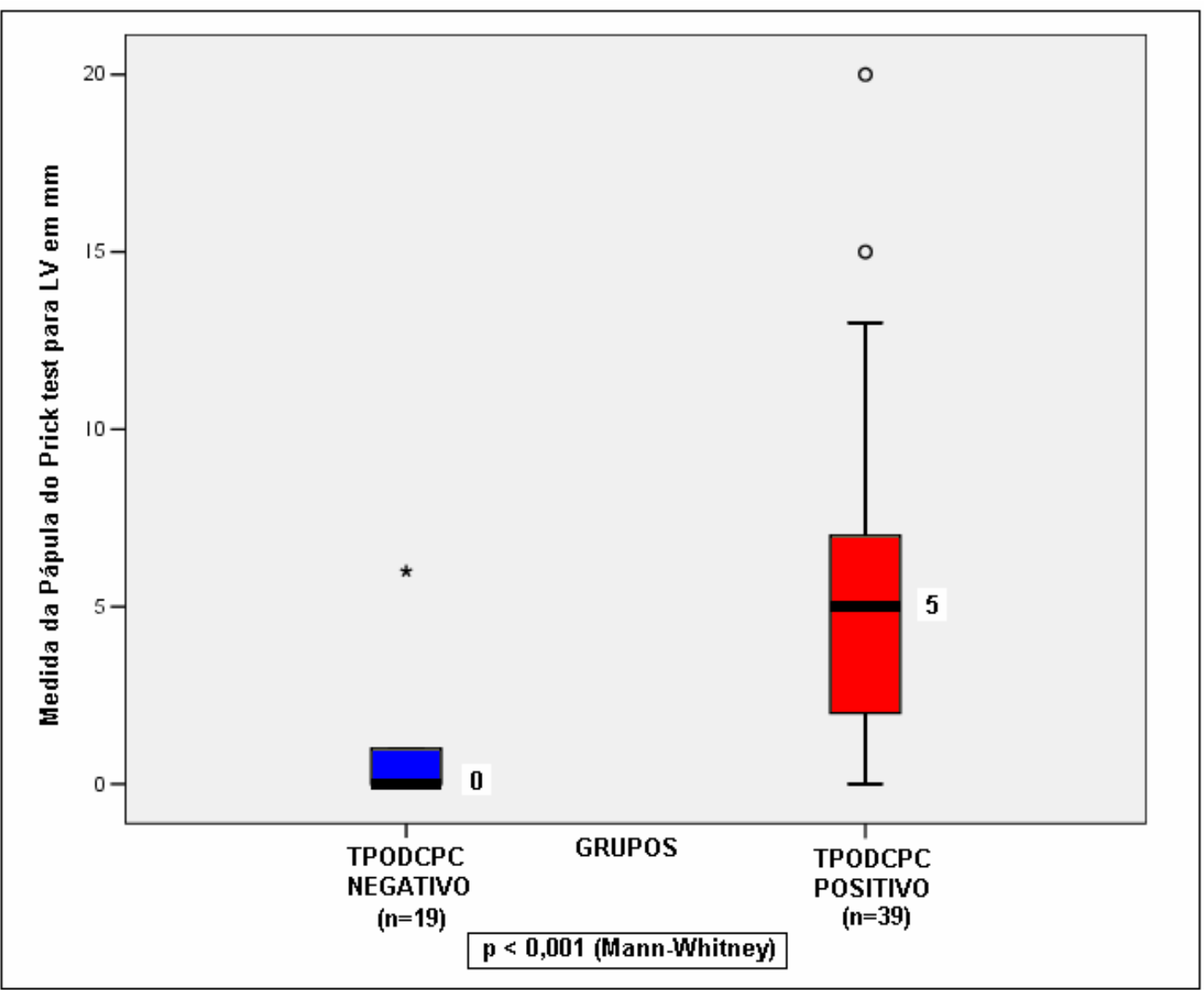


Gráfico 6: Distribuição das medidas da pápula do Prick Test para $\beta$ lactoglobulina nos grupos com TPODCPC negativo e positivo

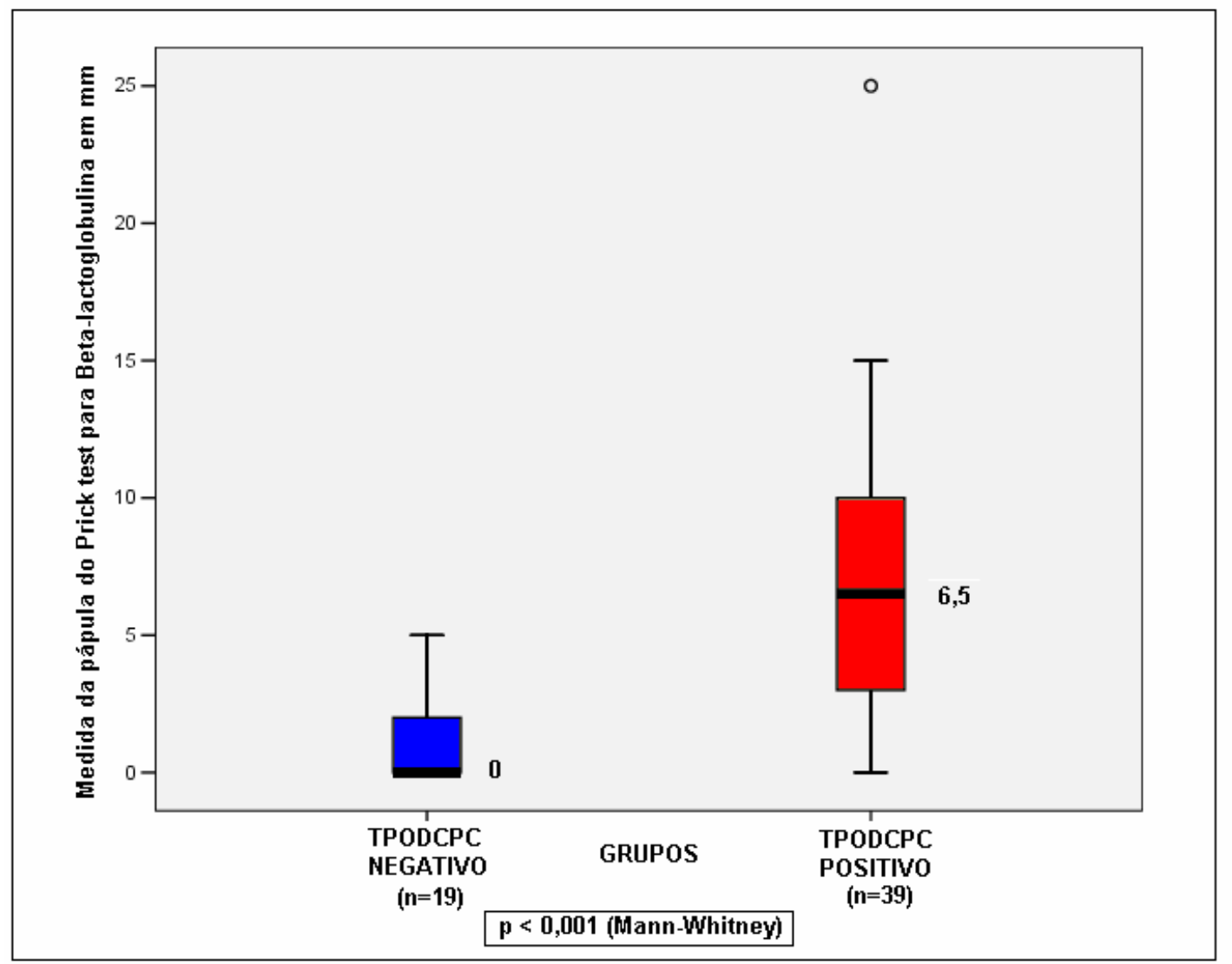


Gráfico 7: Distribuição das medidas da pápula do Prick Test para Caseína nos grupos com TPODCPC negativo e positivo

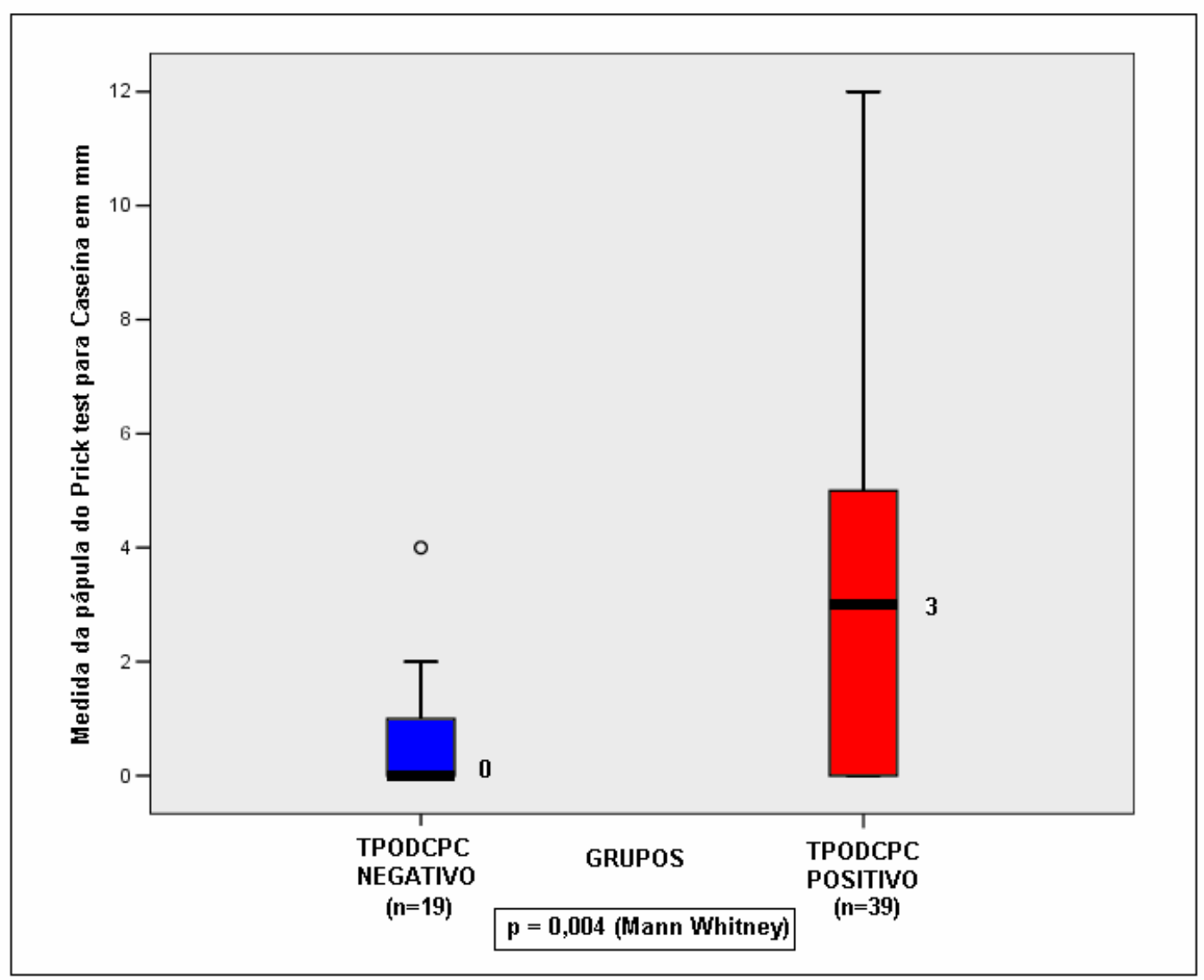


Gráfico 8: Distribuição das medidas da pápula do Prick Test para $L V$ in natura nos grupos com TPODCPC negativo e positivo

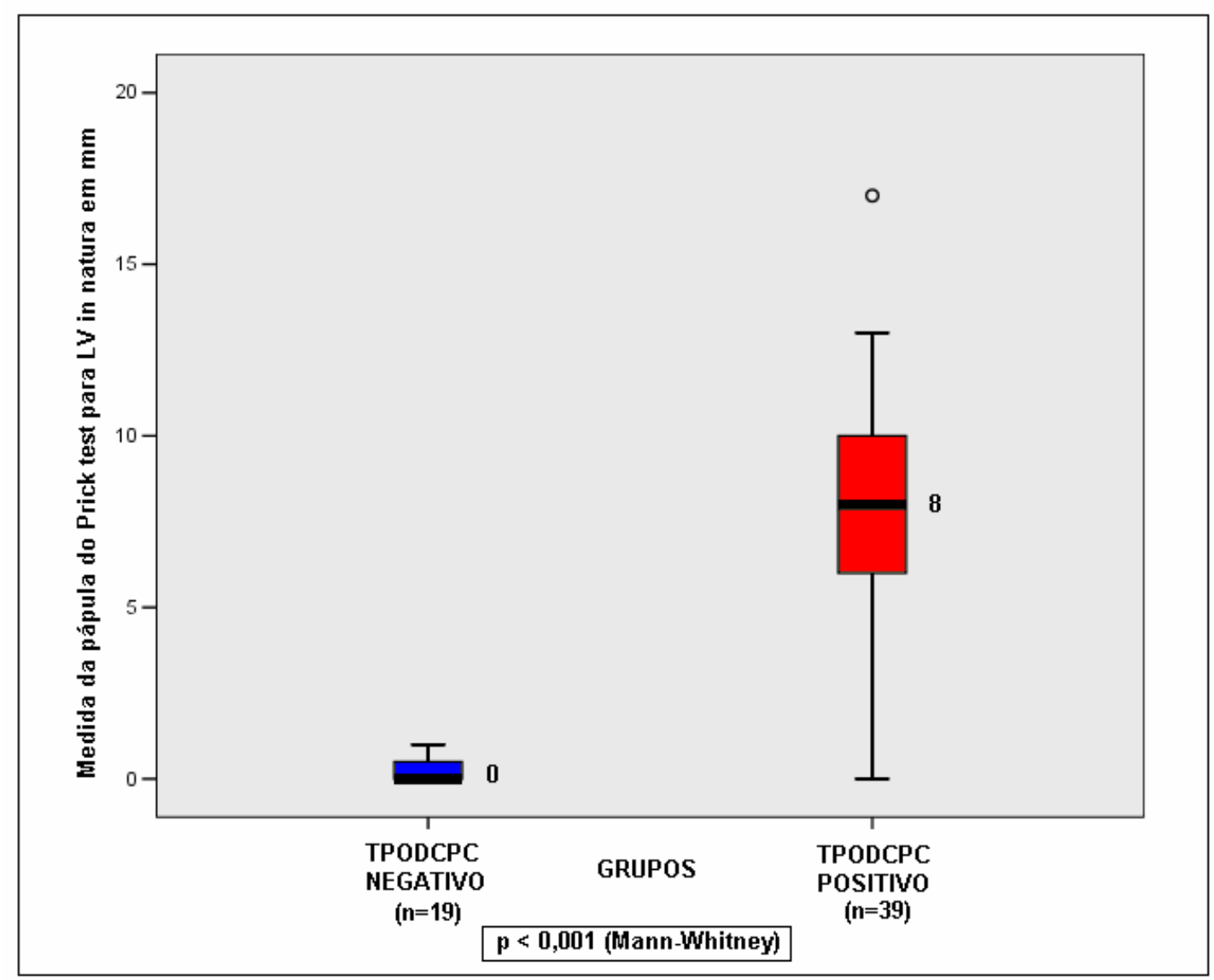


Discussão 


\section{DISCUSSÃO}

A alergia ao leite de vaca é a principal AA na infância com uma prevalência de 2\% a 3\% na população geral (HOST, 2002).

No Brasil, não temos dados de prevalência desta doença com metodologia adequada. VIEIRA et al. (2005) elaboraram um inquérito realizado através de entrevista por telefone com dados fornecidos por gastroenterologistas, encontrando $7,4 \%$ entre 9478 crianças.

Para o diagnóstico de AA, dispomos de dados da anamnese e exames laboratoriais para a pesquisa de IgE específica porém o exame considerado Padrão Ouro é o TPODCPC (SAMPSON, 1999). Este exame é realizado em outros países há mais de três décadas sendo descritas diferentes metodologias. Nos últimos anos, pesquisadores têm sugerido propostas de padronização deste importante método diagnóstico para que os resultados possam ser comparados entre os diferentes serviços.

O Instituto da Criança do HCFMUSP é um hospital de referência nacional com atendimento a nível terciário. A Unidade de Alergia e Imunologia deste hospital possui um ambulatório especializado em AA. Desde a sua criação, em 2003, verificou-se a necessidade de implantar o TPODCPC para o diagnóstico e seguimento dos pacientes deste ambulatório. Como a maioria dos pacientes encaminhados apresentavam a hipótese diagnóstica de APLV, com manifestações clínicas imediatas, optouse por adaptar o TPODCPC ao nosso serviço para o diagnóstico de APLV lgE mediada na faixa etária pediátrica. Esta adaptação apoiou-se 
principalmente na metodologia descrita pelos autores WILLIAM \& BOCK, 1999, já que esta apresenta características mais próximas à nossa necessidade. Através deste estudo, instituímos algumas adaptações compatíveis à disponibilidade de nosso serviço e à realidade de nossa população.

A busca por um local ideal para a realização do TPODCPC nos levou a escolher o hospital dia do Instituto da Criança do HCFMUSP. De acordo com a literatura, o hospital dia é um local com condições suficientes para a realização deste tipo de exame (NIGGEMANN \& BEYER, 2007) desde que preencha os requisitos descritos na metodologia. O local escolhido preenche todos os requisitos necessários com uma ressalva: embora existam aparelhos e pessoal capacitado para a ocorrência de reações graves, este hospital dia não dispõe de uma sala de procedimento isolada para estabilização sendo que os pacientes graves devem ser transferidos para uma unidade de terapia intensiva. A presença de um médico intensivista durante a realização dos últimos exames trouxe maior tranqüilidade à equipe.

A copa deste hospital dia está localizada próxima às enfermarias e está adequadamente equipada para o preparo e conservação das porções utilizadas no TPODCPC. Os profissionais da equipe médica mostraram-se capacitados a acompanhar os testes, entendendo a finalidade do mesmo e auxiliando no reconhecimento e tratamento de reações.

Como veículo utilizado para esconder ou mascarar alimentos a serem testados durante um TPODCPC, o uso de cápsula opaca é insuperável, pois 
não permite o contato do alimento com as estruturas sensoriais presentes na cavidade oral. Esta prática apresenta desvantagem em pacientes com diagnóstico de SAO já que impedem o contato do alimento com a mucosa oral. Estes pacientes podem ser submetidos a testes com cápsulas e sem cápsulas para avaliar se os sintomas ocorrem devido ao contato oral ou podem ocorrer através da absorção sistêmica (BERNSTEIN et al.,1982). Além de impedir o contato direto do alimento com a mucosa oral, o uso de cápsulas apresenta outras desvantagens: a absorção lenta, dificuldade para o uso em crianças, necessidade do uso de muitas cápsulas para alimentos que necessitam maior concentração para desencadear sintomas e reação adversa ao material com o qual é confeccionada a cápsula (HUIJBERS et al.,1994). O uso de cápsulas também não permite que a dose seja interrompida assim que o sintoma tenha início. Neste estudo, as cápsulas poderiam ter sido utlizadas para os testes realizados em adolescentes, porém é preciso lembrar que a confecção destas envolve custos não compatíveis com a realidade do nosso serviço. Portanto, optou-se por utilizar alimentos como veículos em todos os testes realizados.

$\mathrm{Na}$ fase de degustação dos veículos, uma crítica pode ser feita em relação aos voluntários: poderiam também ter sido convocadas crianças saudáveis, de diversas faixas etárias ao invés de médicos da unidade. Principalmente em relação à palatabilidade, a opinião de crianças refletiria melhor a preferência da população alvo. Mesmo na literatura especializada, não constatamos um grupo de crianças eleitas como degustadores. No estudo realizado por VLIEG-BOERSTRA et al., (2004) para o 
desenvolvimento e validação de materiais para o TPODCPC em crianças, os voluntários convocados para efetuar a degustação também eram adultos.

O veículo utilizado no primeiro TPODCPC foi o manjar, porém foi integralmente rejeitado pela criança. A partir desta experiência, outros veículos foram testados para que se aumentassem as opções de escolha. Dentre todos os veículos testados, optou-se por oferecer ao responsável pelo paciente duas alternativas de escolha: a bebida à base de soja Tonyu® sabores morango e maracujá e a sopa de legumes. No presente estudo, o veículo mais escolhido pelos responsáveis pelos pacientes e o mais utilizado foi a bebida à base de soja da marca Tonyuß. Era facilmente encontrado nos supermercados, mascarou bem o sabor e o odor do leite, foi o que melhor mascarou a cor do leite de vaca e foi bem aceito pelos pacientes. Este é outro ponto do estudo passível de crítica, já que a soja faz parte dos sete alimentos responsáveis por 95\% das AA na infância (BOCK \& ATKINS, 1990). No presente estudo, tomou-se o cuidado de descartar a hipótese de sensibilização à soja, nos pacientes que utilizariam este veículo, através do Prick test e da história clínica. Todos os pacientes submetidos ao TPODCPC com Tonyu® como veículo já faziam uso de produtos à base de soja sem sintomatologia e não apresentavam lgE específica para soja. Se o mecanismo imunológico envolvido fosse o não $\operatorname{lgE}$ mediado, produtos à base de soja não poderiam ser utilizados no teste, já que a prevalência de alergia à soja em pacientes com APLV não lgE mediada pode ser elevada (KLEMOLA et al., 2002). Nestes casos, o ideal seria utilizar fórmulas elementares como veículos, conforme padronizado por alguns autores 
(BOCK et al. 1988; METCALFE \& SAMPSON, 1990, WILLIAMS \& BOCK, 1999, NIESTIJL et al., 1994). Cabe ressaltar que a questão de custo também é um fator limitante em nosso meio, pois o custo das fórmulas elementares é superior àquele das bebidas à base de soja. Portanto, as fórmulas elementares não foram utilizadas em nosso estudo por serem produtos pouco acessíveis devido ao alto custo e por serem pouco palatáveis. Outros veículos também são citados para serem utilizados nos TPODCPC como sucos de uva, papas de maçã e fórmulas de soja (BOCK, 1988).

Encontramos, na literatura, descrição dos materiais utilizados em nosso estudo (HUIJBERS et al., 1994; VLIEG-BOERSTRA et al., 2004; GELLERSTEDT et al., 2004; NIGGEMANN \& BEYER, 2007). O que ao final do estudo parece ser óbvio, no início deste estudo não nos pareceu ser importante a necessidade da opacidade total dos materiais. Neste estudo, o uso destes materiais foi muito importante, pois evitaram o contato visual e a percepção do odor do LV. Introduzimos a utilização de suporte para copos, coloridos e opacos, para vedar completamente o conteúdo das porções. Não há, na literatura, descrição do uso de tais suportes. A possibilidade de utilização destes recipientes mascarando importantes aspectos do LV, como a cor e o odor, permite ampliar as opções de veículos. Os sucos de frutas comercializados em embalagem Tetra Pak® foram utilizados por cinco pacientes deste estudo, com boa aceitação. Principalmente as bebidas que contenham a polpa ou o suco natural da fruta, com várias opções de sabor, com aromatizantes e corantes naturais, sem proteínas e sem sódio como é o caso dos sucos da marca Del Valle® representam boas opções. 
Neste estudo, optou-se pela escolha do LV em sua forma líquida conforme sugerido por WILLIAMS \& BOCK (1999) e NIGGEMANN \& BEYER (2007). Uma das principais adaptações realizadas neste estudo foi em relação ao uso de LV com baixo teor de lactose durante o TPODCPC. Com esta medida, descarta-se a possibilidade de reações após o exame devido à deficiência secundária de lactase. Esta deficiência pode ocorrer após dieta de exclusão de leite de vaca por tempo prolongado, ou seja, por falta de estímulo para a produção desta enzima. A ingestão de lactose por estes indivíduos pode produzir manifestações clínicas que variam de um ligeiro desconforto abdominal até o surgimento de quadro diarréico e vômitos. O aparecimento de sintomas depende da dose de lactose consumida e do grau de adaptação colônica (HEYMAN, 2006). Não há, na literatura científica, descrição do uso de LV com baixo teor de lactose durante o TPODCPC.

A concentração do alimento suspeito nas porções do teste deve ser a mais alta possível sem que possa ser detectada pelo paciente (HUIJBERS et al., 1994; BOCK et al.1988, RANCÉ et al., 1999). Nos testes realizados, a dose máxima de $\mathrm{LV}$ foi de $25 \mathrm{~mL}$ adicionada em $30 \mathrm{~mL}$ de veículo, totalizando $100 \mathrm{~mL}$ de LV durante a toda a fase cega. Na terceira fase (TPO aberto), foram oferecidos $200 \mathrm{~mL}$ de LV, totalizando $300 \mathrm{~mL}$ durante todo teste. O volume de LV na fase cega corresponde à dose de 8 a $10 \mathrm{~g}$ do alimento seco recomendado na literatura para TPODCPC (WILLIAMS \& BOCK, 1999). 
O preenchimento do Check list antes de iniciar o teste permitiu identificar pacientes que não estavam em condições para o mesmo. Em relação às modificações no Check list sugerida por WILLIAMS \& BOCK (1999), o tempo de jejum foi aumentado de 2 a 3 horas para 10 horas, possibilitando melhor aceitação de todas as porções oferecidas no teste, pelas crianças. Em relação ao uso de anti-histamínico, de acordo com BOCK et al. (1988), deveria ser suspenso 10 dias antes para hidroxizine e $96 \mathrm{~h}$ para outros. Optou-se por uniformizar a orientação de se evitar o uso durante os 10 dias anteriores ao teste para todos os anti-histamínicos.

A maior dificuldade relatada por pacientes e familiares na fase pré e pós teste foi evitar alimentos sem corantes e conservantes já que o consumo de produtos alimentícios industrializados com estes componentes faz parte da rotina de muitas famílias.

Os cancelamentos dos testes na fase pré teste, do ponto de vista da instituição, resultou na não ocupação dos leitos que estavam bloqueados para a realização dos mesmos. O hospital dia do Instituto da Criança do HCFMUSP é utilizado para o atendimento de diversos pacientes de outras unidades e a reserva de leitos deve ser realizada com antecedência. Além disto, os serviços da equipe multiprofissional composta pelo médico, nutricionista e enfermagem mobilizados para executar o teste tiveram que ser dispensados nestas ocasiões.

As principais adaptações realizadas no esquema proposto por WILLIAMS \& BOCK (1999) foram em relação às doses do placebo e do LV e do intervalo de tempo entre as doses. Optou-se pelo aumento gradativo dos 
volumes, com a repetição apenas da dose maior. O volume total do LV permaneceu o mesmo, ou seja, $100 \mathrm{~mL}$ na fase cega. Em relação aos intervalos entre as doses, o tempo foi prolongado de 10 minutos para 15 a 30 minutos dependendo do relato na história clínica de tempo do aparecimento dos sintomas e da aceitação das porções pelos pacientes. Observou-se que, para as crianças menores, foram necessários intervalos maiores de 15 minutos. Esta alteração não interferiu na duração total do teste: os autores citados sugerem um período de duas horas de observação após a primeira fase e mais uma hora de intervalo para o almoço. Neste estudo, o intervalo para observação somou-se ao intervalo de almoço totalizando duas horas entre uma fase e outra (WILLIAMS \& BOCK,1999).

Em relação ao acesso venoso, observou-se neste estudo, que a escolha pela manutenção através da solução fisiológica em gotejamento lento contínuo permitiu uma melhor monitorização. Com a adoção desta medida, os pacientes permaneceram no leito em tempo integral e tanto a equipe de enfermagem, quanto os acompanhantes puderam averiguar a manutenção do acesso.

As manifestações clínicas mais freqüentes apresentadas durante o TPODCPC foram as pápulas perilabiais e o prurido de orofaringe. Tais manifestações ocorreram devido ao contato do LV com a mucosa oral e não seriam observadas se fossem utilizadas cápsulas. O aparecimento de pápulas perilabiais isoladas, muitas vezes, dificultaram a interpretação do exame já que são manifestações que podem ocorrer de forma inespecífica após o contato da pele com diferentes produtos (CLEMMENSEN, 1982). 
Outros sinais e sintomas também foram freqüentes como espirros, tosse, urticária e vômitos. Além das manifestações de SAO que ocorreram em 33 pacientes, os aparelhos acometidos por ordem decrescente foram: trato respiratório, pele e trato gastrintestinal. BOCK \& ATKINS (1990) descrevem sintomas cutâneos como os mais freqüentes seguidos por sintomas do trato gastrintestinal e respiratório. Estes autores relatam os sintomas de SAO na fase aberta do teste após as fases cegas com cápsulas. ROEHR et al.(2004) descrevem as manifestações da $\mathrm{SAO}$ como as mais freqüentes durantes TPO abertos e duplo-cegos, porém os principais alimentos desencadeantes foram a maçã e a avelã. No presente estudo, observou-se uma freqüência elevada de sintomas nasais (40 descrições). Na literatura, são relatados uma freqüência maior de sintomas respiratórios, principalmente nasais, durante TPODCPC não coincidindo com a sintomatologia relatada na história clínica. Tal fato reflete a não associação de sintomas respiratórios à $A A$ observada pelos responsáveis ou pelos próprios pacientes (JAMES, 2003).

Neste estudo, 14 pacientes do grupo 1 apresentaram sintomas inequívocos e tiveram seus testes concluídos sem a fase placebo. BOCK \& ATKINS (1990) descreveram a experiência adquirida com a realização de 1014 TPODCPC em 480 crianças. Estes autores relataram que o aparecimento de sintomas inequívocos durante as provocações tornaram a realização da fase placebo desnecessária. Nove pacientes do grupo 1 foram submetidos às três fases do teste para confirmar o diagnóstico. Entre eles, dois pacientes só apresentaram sintomas na fase aberta. Segundo BOCK et al.(1988), três possibilidades podem explicar a presença de 
sintomatologia apenas na fase aberta, após a fase cega negativa: dose insuficiente do alimento desencadeante na fase cega, alteração da alergenicidade do alimento desencadeante durante o preparo da fase cega ou fator psicológico produzindo o sintoma. É provável que nestes dois casos relatados neste estudo, a dose oferecida na fase cega tenha sido insuficiente para desencadear os sintomas. Não houve alteração da alergenicidade pois não utilizamos LV processado. Além do que, as proteínas do LV são bastante estáveis. Outra hipótese associada a esta é a de que estes pacientes estejam na fase de transição para a tolerância clínica. Este dado reforça a importância em se realizar a fase aberta mesmo após as duas fases cegas serem negativas.

Não houve necessidade de confirmação do resultado através da fase aberta em 16 pacientes que foram submetidos apenas às fases cegas, com LV e placebo. Estes pacientes apresentaram sintomas após a ingestão do LV que reproduziram os descritos na história clínica e não apresentaram sintomatologia na fase placebo. Dez foram medicados e dispensados da realização do teste aberto. Seis não necessitaram receber medicação, ficaram em observação e foram dispensados da fase aberta.

Em relação aos sintomas subjetivos, BRUJINZEEL-KOOMEN et al. (1995) sugerem que nas situações em que apenas estes estejam presentes, o teste seja repetido em momento posterior.

Sabe-se que as reações de hipersensibilidade imediata podem ser bifásicas, com a fase imediata com reações ocorrendo em menos de duas horas após a ingestão e com a fase tardia com reações ocorrendo várias 
horas após a ingestão (NOWAK-WEGRZYN \& SAMPSON ,2006). Entre os testes realizados neste estudo, foram observados seis pacientes do grupo 1 que apresentaram sintomas imediatos e, mais de 2 horas da última dose de $\mathrm{LV}$, outros sintomas. Os últimos sintomas foram diferentes dos sintomas imediatos. Dois pacientes apresentaram os sintomas coincidentes com a fase placebo, dificultando a interpretação do teste. Os demais, relataram o aparecimento dos sintomas em casa sendo que dois pacientes necessitaram atendimento em pronto socorro devido aos vômitos e diarréia. Estes dados relatados reforçam a necessidade de se acompanhar os pacientes nas horas seguintes ao TPODCPC. Este acompanhamento pode ser realizado viabilizando o contato do paciente com o médico responsável pelo teste através do telefone. Outro fato a ser analisado é a ocorrência de sintomas provavelmente tardios decorrentes de reação ao LV, coincidindo com a fase placebo. Nestes casos, quando há dúvidas na interpretação dos testes, deve-se repeti-los e de preferência com as fases placebo e LV em dias diferentes.

BOCK E ATKINS (1990), relataram reações na fase placebo em $5 \%$ dos testes realizados. Neste estudo, $11,3 \%$ (5/44) dos pacientes apresentaram reação na fase placebo. Quatro apresentaram sintomas logo na primeira fase ou seja, não haviam ingerido LV. Um paciente havia passado pela fase do LV sem sintomas, apresentou vômito na fase placebo e não apresentou sintomas na fase aberta do LV. Permaneceu em observação por mais de 2 horas após o teste sem novos sintomas. Todas as reações foram leves, inespecíficas, com resolução espontânea e não 
reproduziram os sintomas relatados na história clínica. Representam fatores de confusão, dificultando a interpretação do teste. A realização da fase aberta ou a repetição do teste em outro momento são soluções para assegurar uma adequada interpretação do teste.

Ainda em relação à sintomatologia apresentada durante o teste, neste estudo, se aplicarmos a classificação de gravidade dos sintomas sugerida por MURARO et al.(2007), teríamos todos os pacientes com sintomas considerados leves ou moderados e nenhum grave. Conforme as recomendações sugeridas neste consenso, deveríamos aplicar a epinefrina intra-muscular em apenas um paciente que apresentou estridor laríngeo. Nesta casuística, a epinefrina intra-muscular foi aplicada em cinco pacientes: um apresentou estridor laríngeo, três apresentaram sibilância leve associada a urticária ou angioedema e um paciente apresentou prurido em orofaringe, sintomas de rinite e tosse. Nestes últimos casos, a epinefrina foi indicada pois os pacientes tinham história anterior de anafilaxia. BOCK \& ATKINS (1990) relataram o uso de epinefrina intra-muscular em apenas 4 de 480 pacientes que realizaram o TPODCPC. Estes autores relatam que em 1014 TPODCPC realizados, não houve nenhum caso de queda na pressão arterial ou comprometimento respiratório grave. O mesmo pode ser afirmado em relação aos pacientes deste estudo. Os dados obtidos em relação à sintomatologia, somados aos dados da literatura, demonstram que trata-se de um exame seguro mas que necessita cuidados para a sua execução pois não é isento de riscos. 
Em relação à dose que desencadeou os sintomas relatados na história comparada à dose que provocou sintomas durante o TPODCPC, a diferença foi de apenas $5 \mathrm{~mL}$ entre as medianas e médias. Esta constatação reforça a importância dos dados obtidos durante a anamnese, principalmente na decisão da dose inicial do alimento a ser dada durante 0 teste. TAYLOR et al. (2004) sugerem que, apesar da dose inicial ser de 250 mg a $500 \mathrm{mg}(2,5 \mathrm{~mL}$ a $5 \mathrm{~mL}$ de LV) para a maioria dos pacientes sensíveis, esta dose não deveria ser padronizada e sim individualizada. Os autores iniciaram com doses de $10 \mu \mathrm{g}$ atingindo $100 \mathrm{mg}$, estabelecendo também níveis protetores para indivíduos alérgicos de acordo com cada alimento, acima dos quais aumentam os riscos de reação. Para o LV, este nível seria de $8,6 \mathrm{mg}$.

História familiar positiva de atopia tem sido frequentemente associada a risco aumentado de atopia nas crianças, sendo a mãe mais frequentemente envolvida (OR=5,0) (LITONJUA et al 1998). Neste estudo, a associação entre atopia familiar e APLV não foi estatisticamente significante porém cabe lembrar que este dado depende da informação e da lembrança do familiar e o diagnóstico em muitos casos não foi médico.

Em relação à atopia pessoal, existem trabalhos que demonstram associação entre outras atopias e alergia alimentar (EIGENMANN et al., 1998; JAMES, 2003). Neste estudo, esta associação foi estatisticamente significante. Tais dados reforçam a necessidade de orientação durante o acompanhamento dos pacientes com $\mathrm{AA}$ em relação à alergia respiratória, dermatite atópica e à alergia a outros alimentos. 
Os exames laboratoriais demonstraram uma grande variação entre os resultados demonstrando a heterogeneidade entre os pacientes. Por este motivo, utilizou-se a análise das medianas dos resultados obtidos para a comparação entre os grupos 1 e 2.

Após a análise dos resultados, verificou-se que os critério clínicoepidemiológicos e laboratoriais adotados para definir os pacientes com história sugestiva de APLV IgE mediada foram compatíveis com os resultados dos TPODCPC. Este dado aponta para a utilização deste "score" clínico-epidemiológico e laboratorial como possível ferramenta para dispensar pacientes da realização do TPODCPC, principalmente em serviços que ainda não dispõem de estrutura apropriada para a realização deste exame. Este fato necessita ser reavaliado através de metodologia adequada em diferentes populações.

BAHNA (1995) sugere que, apesar das propostas de padronização do teste, alguns aspectos podem ser individualizados como o veículo, placebo, a dose do alimento a ser testado e o tempo de observação. A aquisição de conhecimento sobre $\mathrm{AA}$ pelo médico que acompanha o teste e sua experiência adquirida, tornam o procedimento cada vez mais seguro e a interpretação dos resultados mais objetiva. Nos EUA, o American Board of Allergy and Immunology incluiu o teste de Provocação Oral entre os procedimentos requeridos para o treinamento de alergistas em todos os programas nacionais de especialização em alergia e imunologia (BAHNA, 1995). 
Neste estudo, buscou-se principalmente a implantação deste importante método diagnóstico no Instituto da Criança do HCFMUSP para o diagnóstico e acompanhamento dos pacientes do ambulatório de alergia alimentar. A adaptação proposta viabilizou seu uso para suprir as necessidades deste ambulatório. O TPODCPC mostrou-se exeqüível apesar das dificuldades encontradas. Pode-se sugerir, através desta adaptação, uma maneira prática para a realização do TPODCPC também em outras instituições que acompanham pacientes com AA conforme as disponibilidades e necessidades locais de cada serviço. 


\section{CONCLUSÕES}

a) A adaptação do TPODCPC foi possível, para o diagnóstico de APLV na faixa etária pediátrica, no Instituto da Criança do HCFMUSP, sendo necessária a avaliação da sua reprodutibilidade em outras populações.

b) O TPODCPC mostrou-se seguro, desde que realizado em ambiente hospitalar com condições para o atendimento de reações graves e com profissionais habilitados.

c) Embora o TPODCPC seja considerado como padrão ouro para o diagnóstico da APLV, neste estudo observou-se dificuldade na interpretação de sinais e sintomas inespecíficos.

c) Observou-se associação significante entre a positividade do TPODCPC e os antecedentes de atopia.

d) Observou-se associação significante entre a positividade do TPODCPC e as concentrações séricas de IgE específicas para o LV e frações $\alpha$-lactoalbumina, $\beta$-lactoglobulina e caseína.

e) Observou-se associação significante entre a positividade do TPODCPC e a positividade do Prick test para LV e as frações: $\beta$ lactoglobulina, caseína e LV in natura. 
Anexo A- Check list para a realização do Teste de Provocação Oral Duplo Cego Placebo Controlado

\section{Check list para o teste de provocação oral}

(1) O alimento a ser testado foi rigorosamente evitado durante as duas semanas anteriores

(1) Anti-histamínicos foram evitados nos últimos 10 dias

(1) Broncodilatadores, cromoglicatos e esteróides inalatórios foram evitados nas últimas 12 horas

Termo de consentimento assinado

Acompanhante maior que 18 anos de idade

Equipamentos e drogas para tratar anafilaxia disponíveis

Paciente em jejum por pelo menos 6 horas

Acesso venoso 


\section{Anexo B- Protocolo Padronizado para o Teste de Provocação Oral Duplo Cego Placebo Controlado (página 1)}

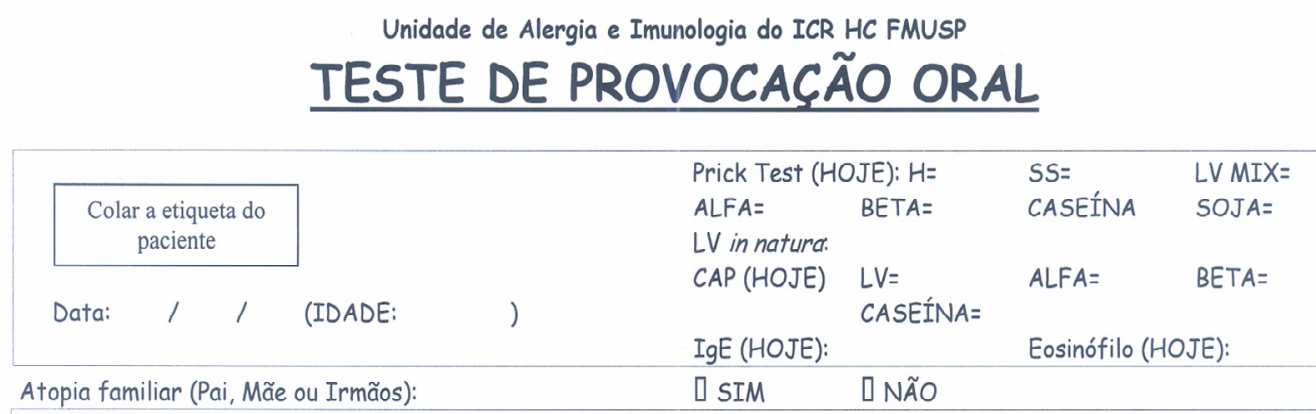

\section{MANIFESTAÇÕES CLÍNICAS DA ALERGIA ALIMENTAR}

Idade de início:

Alimento suspeito:

Quantidade que provocou a reação:

Forma de preparo:

Intervalo de tempo descle a última reação:

Intervalo de tempo entre a ingestão do alimento e o aparecimento dos sintomas:

Tratamento recebido:

Manifestações Dermatológicas: DEritema DUrticária Dangioedema Dprurido DEczema

ISAO

Gastro-Intestinais: Uvômitos DDiarréia DDor Abdominal UNáusea

UFlatulência DEnterorragia UAftas Dprurido/Dor Em Orofaringe

Respiratórias: UChiado UEstridor UTosse DDificuldade Respiratória

DPrurido Nasal DEspirros Dobstrução Nasal ]Coriza

IConjuntivite DLacrimejamento

Manifestações Sistêmicas:

\section{DIAGNÓSTICOS SECUNDÁRIOS}

\section{MEDICAMENTOS}

Medicamentos utilizados nas últimas 24 horas:

Medicamentos utilizados nos últimos 10 dias:

Medicamentos utilizados nos últimos 30 dias: 


\section{Anexo B- Protocolo Padronizado para o Teste de Provocação Oral Duplo} Cego Placebo Controlado (página 2)
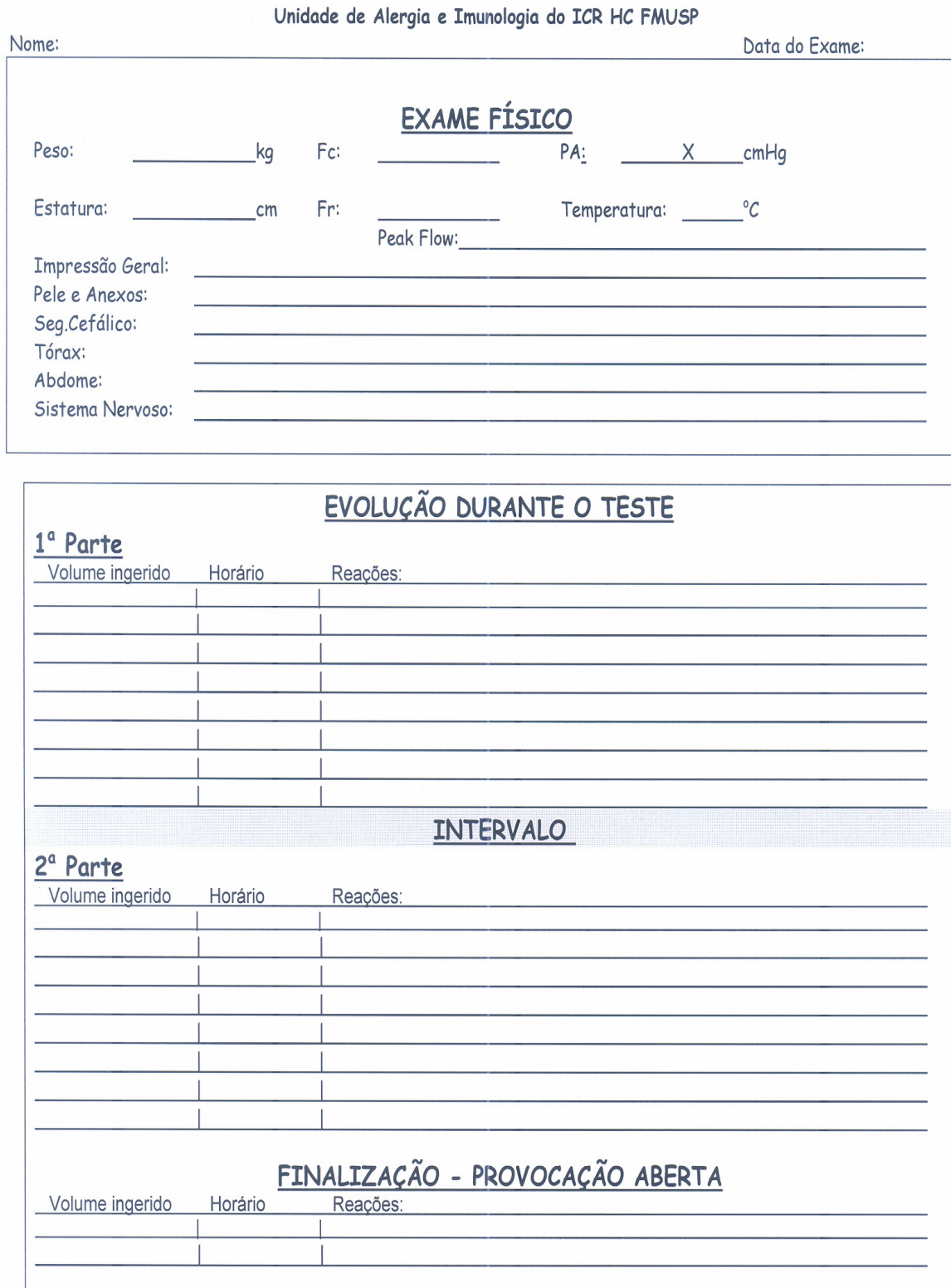

VEÍCULO UTILIZADO= $1^{\text {a }}$ Parte $=$ $2^{a}$ Parte $=$

LEITE DE VACA (BAIXO TEOR DE LACTOSE) DOSE INICIAL:

RESULTADO DO TESTE=

KLOULIMUU UU ILOIC= 


\title{
Anexo C- Aprovação do Projeto de Pesquisa
}

\author{
HOSPITAL DAS CLINICAS \\ FACULOADE DE MEDICINA DA UNIVERSIDADE DE SÄO PAULO \\ CAIXA POSTAL, 3671 \\ SÁO PALLO - BRASH \\ DIRETORIA CLÍNICA
}

\section{Cómissão de Ética para Análise de Projetos de Pesquisa}

\section{APROVACÃO}

A Comissão de Ética para Análise de Projetos de Pesquisa - CAPPesq da Diretoria Clínica do Hospital das Clínicas e da Faculdade de Medicina da Universidade de São Paulo, em sessão de 12.06.02, APROVOU O Protocolo de Pesquisa $n^{\circ}$ 325/02, intitulado: "Padronização do teste de provocação oral duplo-cego, placebo controlado para o diagnóstico de alergia à proteína do leite de vaca mediada por IgE", do Departamento de PEDIATRIA, bem como o Termo de Consentimento Livre e Esclarecido.

Pesquisador(a) Responsável: DRA. CRISTINA MIUKI ABE JACOB

Pesquisador(a) Executante: DRA. ANDREA KEIKO FUJINAMI GUSHKEN

CAPPesq, 12 de Junho de 2002.

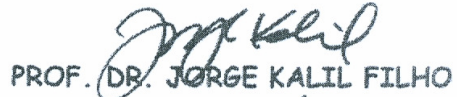

Presidente da Comissão de Ética para Análise de Projetos de Pesquisa

OBSERVAÇÃO: Cabe ao pesquisador elaborar e apresentar a CAPPesq, os relatórios parciais e final sobre a pesquisa (Resolução do Conselho Nacional de Saude $n^{\circ} 196$, de 10.10.1996, inciso IX.2, letra " $c$ "). 


\title{
Anexo D - Termo de Consentimento Livre e Esclarecido (folha 1)
}

\author{
HOSPITAL DAS CLÍNICAS \\ DA \\ FACULDADE DE MEDICINA DA UNIVERSIDADE DE SÃO PAULO \\ TERMO DE CONSENTIMENTO LIVRE E ESCLARECIDO
}

(Instruções para preenchimento no verso)

I - DADOS DE IDENTIFICAÇÃO DO SUJEITO DA PESQUISA OU RESPONSÁVEL LEGAL

1. NOME DO PACIENTE :

DOCUMENTO DE IDENTIDADE No : SEXO: $M \quad F$

DATA NASCIMENTO: ........................

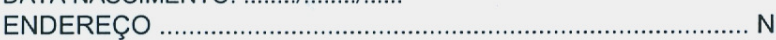

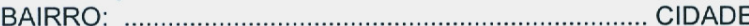

CEP.

2.RESPONSÁVEL LEGAL

NATUREZA (grau de parentesco, tutor, curador etc.)

DOCUMENTO DE IDENTIDADE

.SEXO: $M \quad F$

DATA NASCIMENTO : I I

ENDEREÇO:

... $\mathrm{N}^{\circ}$

$\mathrm{F}$

BAIRRO: CIDADE:

CEP: ......................................... TELEFONE: DDD (...........)

II - DADOS SOBRE A PESQUISA CIENTÍFICA

1. TÍTULO DO PROTOCOLO DE PESQUISA Padronização do teste de provocação oral duplo cego placebo controlado para o diagnóstico de alergia à proteína do leite de vaca mediada por IgE.

\section{PESQUISADORA: ANDREA KEIKO FUJINAMI GUSHKEN}

CARGO/FUNÇÃO: MÉDICA COLABORADORA DA UNIDADE DE ALERGIA E IMUNOLOGIA DO ICR - HCFMUSP INSCRIÇÃO CONSELHO REGIONAL Nº 68.510 UNIDADE DO HCFMUSP: UNIDADE DE ALERGIA E IMUNOLOGIA DO ICR HC FMUSP

3. AVALIAÇÃO DO RISCO DA PESQUISA:

$\begin{array}{llll}\text { SEM RISCO } & \text { RISCO MINIMO } & \\ \text { RISCO BAIXO } & \text { RISCO MAIOR } & X\end{array}$

(probabilidade de que o individuo sofra algum dano como consequência imediata ou tardia do estudo) 4.DURAÇÃO DA PESQUISA: : DOIS ANOS 


\section{Anexo D - Termo de Consentimento Livre e Esclarecido (folha 2)}

\section{III - REGISTRO DAS EXPLICAÇÕES DO PESQUISADOR AO PACIENTE OU SEU REPRESENTANTE LEGAL SOBRE A PESQUISA, CONSIGNANDO:}

1. Justificativa e os objetivos da pesquisa: Para confirmar o diagnóstico de alergia a leite de vaca em seu filho, estamos desenvolvendo um exame especial neste Hospital, chamado Teste de Provocação Oral.

2. Procedimentos que serão utilizados e propósitos, incluindo a identificação dos procedimentos que são experimentais: Os pacientes com suspeita de alergia a leite de vaca serão inicialmente examinados e farão exames de sangue e testes cutâneos para avaliar o grau de alergia. Após, aqueles que condordarem serão submetidos ao teste de provocação oral. Este exame terá duas partes, sendo que em cada uma delas o paciente deverá ser internado por um período de aproximadamente 6 horas. Durante o exame, serão oferecidas pequenas porções de alimento contendo ou não leite de vaca, em quantidades crescentes e em intervalos de 30 minutos. Caso a criança apresente qualquer sintoma, o exame será interrompido. A criança deverá permanecer em observação por duas horas após o fim do teste. Depois, será liberada para casa, devendo retornar ao Hospital em uma semana para reavaliação.

3. Os desconfortos esperados relacionam-se ao tempo de duração do exame: Será necessário jejum para iniciar o procedimento. Durante todo o período do exame, a criança deverá estar com soro na veia. Seu filho poderá apresentar reações durante o exame como: diarréia, vômitos, coceira no corpo, tosse, chiado e outros sintomas. Caso ocorra alguma reação grave, como o choque anafilático, a equipe médica estará pronta a atender.

4. Benefícios que poderão ser obtidos: O seu filho terá um diagnóstico mais preciso e terá o acompanhamento de uma equipe de médicos e nutricionistas.

\section{IV - ESCLARECIMENTOS DADOS PELO PESQUISADOR SOBRE GARANTIAS DO SUJEITO DA PESQUISA:}

1. Acesso, a qualquer tempo, às informações sobre procedimentos, riscos e benefícios relacionados à pesquisa, inclusive para dirimir eventuais dúvidas: Se seu filho participar do estudo você deverá ser esclarecido de todos os procedimentos que ele irá fazer, será informado dos riscos e benefícios e a qualquer tempo poderá pedir qualquer informação que desejar.

2. Liberdade de retirar seu consentimento a qualquer momento e de deixar de participar do estudo, sem que isto traga prejuízo à continuidade da assistência: A participação ou não do estudo depende de você e se decidir participar, você deverá assinar esse Termo de Consentimento. Você é livre para desistir a qualquer momento desse estudo e sem dar explicações e se decidir não participar isto não afetará de nenhuma maneira a qualidade de tratamento que você recebe em nossa Unidade.

3. Salvaguarda da confidencialidade, sigilo e privacidade: Se você aceitar participar do estudo, todos os seus registros médicos serão armazenados em um computador, mas seu nome não aparecerá nos registros. Somente a equipe médica saberá quais informações estão relacionadas a você. Os resultados do estudo serão publicados em literatura médica, mas sua identidade não será revelada. 


\section{Anexo D - Termo de Consentimento Livre e Esclarecido (folha 3)}

4. Disponibilidade de assistência no HCFMUSP, por eventuais danos à saúde, decorrentes da pesquisa: A Unidade de Alergia e Imunologia deverá atender a qualquer problema de saúde decorrente do teste de provocação oral realizado.

5. Viabilidade de indenização por eventuais danos à saúde decorrentes da pesquisa.

\footnotetext{
V. INFORMAÇÕES DE NOMES, ENDEREÇOS E TELEFONES DOS RESPONSÁVEIS PELO ACOMPANHAMENTO DA PESQUISA, PARA CONTATO EM CASO DE INTERCORRÊNCIAS CLÍNICAS E REAÇÕES ADVERSAS.
}

Os pacientes que participarem do estudo deverão ter Nomes, telefones e BIP de contato com os responsáveis pelo estudo, para poder a qualquer tempo tirar dúvidas sobre o medicamento ou preenchimento dos diários de sintomas.

Ligar Para Unidade de Alergia e Imunologia - Telefone 30698585

Dra ANDREA KEIKO FUJINAMI GUSHKEN - celular: 99887081

Dra CRISTINA MIUKI ABE JACOB - Bip: 34444545 - código: 1049324

VI. OBSERVAÇÕES COMPLEMENTARES:

\section{VII - CONSENTIMENTO PÓS-ESCLARECIDO}

Declaro que, após convenientemente esclarecido pelo pesquisador e ter entendido o que me foi explicado, consinto em participar do presente Protocolo de Pesquisa

São Paulo,

de

de 2

assinatura do sujeito da pesquisa ou responsável legal

assinatura do pesquisado (carimbo ou nome Legível) 
Referências Bibliográficas 


\section{REFERÊNCIAS BIBLIOGRÁFICAS}

American Academy of Pediatics. Committee on Nutrition. Hypoallergenic infant formulas. Pediatrics. 2000;106:346-9.

Axen R, Drevin H, Kober A, Yman L. A new laboratory diagnostic system applied to allergy testing. N Engl Reg Allergy Proc. 1988;9:503.

Bahna SL. Food challenge procedures in research and in clinical practice. Pediatr Allergy Immunol. 1995;6(Suppl 8):49-53.

Bahna SL, Furukawa CT. Food allergy: diagnosis and treatment. Ann Allergy. 1983;51:574-80.

Bernstein M, Day JH, F.R.C.P.(C), and April Weish, B>Sc. Double-blind food challenge in the diagnosis of food sensitivity in the adult. J Allergy Clin Immunol.1982;70 :205-10.

Bindslev-Jensen C, Ballmer-Weber BK, Bengtsson U, Blanco C, Ebner C, Hourihane J, Knulst AC, Moneret-Vautrin DA, Nekam K, Niggemann B, Osterballe M, Ortolani C, Ring J, Schnopp C, Werfel T; European Academy of Allergology and Clinical Immunology. Standardization of food challenges in patients with immediate reactions to foods--position paper from the European Academy of Allergology and Clinical Immunology. Allergy. 2004;59:690-7. 
Bindslev-Jensen C. Standardization of double-blind, placebo-controlled food challenges. Allergy. 2001;56(Suppl 67):75-7.

Björkstén B. Genetic and environmental risk factors for the development of food allergy. Curr Opin Allergy Clin Immunol. 2005;5:249-53.

Bock SA, Atkins FM. Patterns of food hypersensitivity during sixteen years of double-blind, placebo-controlled food challenges. J Pediatr. 1990;117:561-7.

Bock SA. In vivo diagnosis: skin testing and oral challenge procedures. In: Metcalfe DD, Sampson HA, Simon RA. Food allergy: Adverse reactions to foods and food additives. 2a ed. Massachusetts: Blackwell Science; 1997. p.151-66.

Bock S, Lee W, Remigio L, May C. Studies of hypersensitivity reactions to food in infants and children. J Allergy Clin Immunol. 1978;62:327-34.

Bock SA, Sampson HA, Atkins FM, Zeiger RS, Lehrer S, Sachs M, Bush RK, Metcalfe DD. Double-blind placebo-controlled food challenge (DBPCFC) as an office procedure: A manual. J Allergy Clin Immunol. 1988;82:986-97.

Bock SA, Sampson HA. Food allergy in infancy. Pediatr Clin North Am. 1994; 41:1047-67. 
Brandtzaeg PE. Current understanding of gastrointestinal immunoregulation and its relation to food allergy. Ann NY Acad Sci. 2002;964:13-45.

Brujinzeel-Koomen C, Ortolani C, Aas K, Bindslev-Jensen C, Björkstén B, Moneret-Vautrin D, Wüthrich B.. Position paper of the European Academy of Allergology and Clinical Immunology on adverse reactions to food. Allergy. 1995;12:357-8.

Caffarelli C, Petroccione T. False-negative food challenges in children with suspected food allergy. Lancet. 2001;358:1871-2.

Chehade M, Mayer L. Oral tolerance and its relation to food hypersensitivities. J Allergy Clin Immunol., 2005;115:3-12.

Consenso Brasileiro sobre alergia alimentar. Rev. Bras alerg imunopatol., 2008;31:64-89.

Celik-Bilgili S, Mehl A, Verstege A, Staden U, Nocon M, Beyer K, Niggemann B. The predictive value of specific immunoglobulin E levels in serum for the outcome of oral food challenges. Clin Exp Allergy. 2005;35:268-73.

Champion RH. A practical approach to the urticarial syndromes--a dermatologist's view. Clin Exp Allergy. 1990;20:221-4. 
Clemmensen O, Hjorth N. Perioral contact urticaria from sorbic acid and benzoic acid in a salad dressing. Contact Dermatitis. 1982;8:1-6.

Doria-Filho U. Introdução à bioestatística: para simples mortais. São Paulo: Elsevier; 1999. 158p.

Eigenmann PA. Do we have suitable in-vitro diagnostic tests for the diagnosis of food allergy? Curr Opin Allergy Clin Immunol. 2004;4:211-3.

Eigenmann PA, Sampson HA. Interpreting skin prick tests in the evaluation of food allergy in children. Pediatr Allergy Immunol. 1998;9:186-91.

Eigenmann PA, Sicherer SH, Borkowski TA, Cohen BA, Sampson HA. Prevalence of IgE-mediated food allergy among children with atopic dermatitis. Pediatrics. 1998;101:E8.

Faria AMC, Weiner HL. Oral tolerance. Immunol Rev. 2005;206:232-59.

Garcia-Ara C, Boyano-Martínez T, Díaz-Pena JM, Martín-Muñoz F, RecheFrutos M, Martín-Esteban M. Specific IgE levels in the diagnosis of immediate hypersensitivity to cows' milk protein in the infant. $J$ Allergy Clin Immunol. 2001;107:185-90. 
Garside $\mathrm{P}$, Milligton $\mathrm{O}$, Smith $\mathrm{KM}$. The anatomy of mucosal immune responses. Ann N y Acad Sci. 2004;1029:9-15.

Gellerstedt M, Magnusson J, Gråjö U, Ahlstedt S, Bengtsson U. Interpretation of subjective symptoms in double-blind placebo-controlled food challenges - interobserver reliability. Allergy. 2004;59:354-6.

Gushken AKF, Castro ABM, Pastorino AC, Ciccione AC, Gonçalves RFF, Jacob CMA. Estabilishing a milk specific IgE decision point in IgE mediated cow's milk allergy (CMA) patients from a tertiary pediatric Brazilian Center. $J$ Allergy Clin Immunol. 2006;117(Suppl 44):P176.

Goldman AS, Anderson DW Jr, Sellers WA, Saperstein S, Kniker WT, Halpern SR. Milk allergy. I: Oral challenge with milk and isolated milk proteins in allergic children. Pediatrics. 1963;32:425-43.

Greer FR, Sicherer SH, Burks AW; American Academy of Pediatrics Committee on Nutrition; American Academy of Pediatrics Section on Allergy and Immunology. Effects of early nutritional interventions on the development of atopic disease in infants and children: the role of maternal dietary restriction, breastfeeding, timing of introduction of complementary foods, and hydrolyzed formulas. Pediatrics. 2008;121:183-91. 
Hahn EL, Bacharier LB. The atopic march: the pattern of allergic disease development in childhood. Immunol Allergy Clin North Am. 2005;25:231-46.

Heyman MB, Committee on Nutrition. Lactose intolerance in infants, children and adolescents. Pediatrics. 2006;118:1279-86.

Hill DJ, Heine RG, Hosking CS. The diagnostic value of skin prick testing in children with food allergy. Pediatr Allergy Immunol. 2004;15:435-41.

Høst A. Frequency of cow's milk allergy in childhood. Ann Allergy Asthma Immunol. 2002;89(6 Suppl 1):33-7.

Høst A, Halken S. A prospective study of cow milk allergy in Danish infants during the first 3 years of life. Clinical course in relation to clinical and immunological type of hypersensitivity reaction. Allergy. 1990;45:587-96.

Huijbers GB, Colen AA, Jansen JJ, Kardinaal AF, Vlieg-Boerstra BJ, Martens BP. Masking foods for food challenge: practical aspects of masking foods for a double-blind, placebo-controlled food challenge. J Am Diet Assoc. 1994;94:645-9.

Isolauri E. Probiotics in the prevention and treatment of allergic disease. Pediatr Allergy Immunol. 2001;12(Suppl 14):56-9. 
Isolauri E,Turjanmaa K. Combined skin prick and patch testing enhances indentification of food allergy in infants with atopic dermatitis. $J$ Allergy Clin Immunol. 1996;97:9-15.

Jakobsson I, Lindberg T. A prospective study of cow's milk protein intolerance in Swedish infants. Acta Paediatr Scand. 1979;68:853-9.

James JM. Respiratory manifestations of food allergy. Pediatrics. 2003;111:1625-30.

Johansson SG, Bieber T, Dahl R, Friedmann PS, Lanier BQ, Lockey RF, Motala C, Ortega Martell JA, Platts-Mills TA, Ring J, Thien F, Van Cauwenberge P, Williams HC. Revised nomenclature for allergy for global use: Report of the Nomenclature Review Committee of the World Allergy Organization, October 2003. J Allergy Clin Immunol. 2004;113:832-6.

Karlsson MR, Rugtveit J, Brandtzaeg P. Allergen-responsive CD4+CD25+ regulatory $T$ cells in children who have outgrown cow's milk allergy. $J$ Exp Med. 2004;199:1679-88.

Lack G. Epidemiologic risks for food allergy. J Allergy Clin Immunol. 2008;121:1331-6.

Litonjua AA, Carey VJ. Burge HA, Weiss ST, Gold DR. Parental history and 
the risk for childhood asthma. Does mother confer more risk than father? Am J Respir Crit Care Med. 1998;158:176-81.

May CD. Objective clinical and laboratory studies of immediate hypersensitive reactions to food in asthmatic children. $J$ Allergy Clin Immunol.1976;58:500-15.

Metcalfe DD, Sampson HA. Workshop on experimental methodology for clinical studies of adverse reactions to food and food additives. J Allergy Clin Immunol. 1990;86:421-42.

Muraro A, Roberts G, Clark A, Eigenmann PA, Halken S, Lack G, MoneretVautrin A, Niggemann B, Rancé F; EAACl Task Force on Anaphylaxis in Children. The management of anaphylaxis in childhood: position paper of the European academy of allergology and clinical immunology. Allergy. 2007;62:857-71.

Niggemann B, Beyer K. Diagnosis of food allergy in children: toward a standardization of food challenge. J Pediatr Gastroenterol Nutr. 2007;45:399404.

Niggemann B, Beyer K. Pitfalls in double-blind, placebo-controlled oral food challenges. Allergy. 2007;62:729-32. 
Niggemann B, Wahn U, Sampson HA. Proposals for standardization of oral food challenge tests in infants and children. Pediatr Allergy Immunol. 1994;5:11-3.

Novembre E, De Martinho M, Vierucci A. Foods and respiratory allergy. $J$ Allergy Clin Immunol. 1988;81:1059-65.

Nowak-Wegrzyn A, Sampson H A. Adverse Reactions to Foods. Med Clin N Am. 2006;90:97-127.

Pepys J. Skin testing. Br J Hosp Med. 1975;14:412.

Rance F, Juchet A, Brémont F, Dutau G. Correlations between skin prick tests using commercial extracts and fresh foods, specific $\lg E$, and food challenges. Allergy. 1997;52:1031-5.

Rance F, Kanny G, Dutau G, Moneret-Vautrin D. Food hypersensitivity in children: clinical aspects and distribuition of allergens. Pediatr Allergy Immunol. 1999;10:33-8.

Roehr CC, Edenharter G, Reimann S, Ehlers I, Worm M, Zuberbier T, Niggemann B. Food allergy and non-allergic food hypersensitivity in children and adolescents. Clin Exp Allergy. 2004;34:1534-41.

Rona RJ, Keil T, Summers C, Gislason D, Zuidmeer L, Sodergren E, 
Sigurdardottir ST, Lindner T, Goldhahn K, Dahlstrom J, McBride D, Madsen C. The prevalence of food allergy: a meta-analysis. J Allergy Clin Immunol. 2007;120:638-46.

Saarinen VM, Kajosaari M. Breast feeding as prophylaxis against atopic disease: prospective follow-up until 17 years old. Lancet. 1995;346:1065-9.

Sampson HA. Food Allergy. Parte 1: Immunopathogenesis and clinical disorders. J Allergy Clin Immunol. 1999;103:717-28.

Sampson HA. Utility of food-specific IgE concentrations in predicting symptomatic food allergy. J Allergy Clin Immunol. 2001;107:891-6.

Sampson HA, Albergo R. Comparison of results of skin tests, RAST, and double-blind, placebo-controlled food challenges in children with atopic dermatitis. J Allergy Clin Immunol. 1984;74:26-33.

Sampson HA, Mendelson LM, Rosen JP. Fatal and near-fatal anaphylactic reactions to food in children and adolescents. N Engl J Med. 1992;327:380-4.

Sampson HA, Metcalfe DD. Food allergies. JAMA. 1992;268:2840-44.

Sampson HA, Muñoz-Furlong A, Campbell RL, Adkinson NF Jr, Bock SA, Branum A, Brown SG, Camargo CA Jr, Cydulka R, Galli SJ, Gidudu J, 
Gruchalla RS, Harlor AD Jr, Hepner DL, Lewis LM, Lieberman PL, Metcalfe DD, O'Connor R, Muraro A, Rudman A, Schmitt C, Scherrer D, Simons FE, Thomas S, Wood JP, Decker WW. Second symposium on the definition and management of anaphylaxis: summary report--Second National Institute of Allergy and Infectious Disease/Food Allergy and Anaphylaxis Network symposium. J Allergy Clin Immunol. 2006;117:391-7.

Sicherer SH, Furlong TJ, DeSimone J, Sampson HA. Self-reported allergic reactions to peanut on commercial airliners. J Allergy Clin Immunol. 1999;103:186-9.

Sicherer SH. Manifestations of food allergy: evaluation and management. Am Fam Physician. 1999;15;59:415-24.

Sicherer SH, Morrow EH, Sampson HA. Dose-response in double-blind, placebo-controlled oral food challenges in children with atopic dermatitis. $J$ Allergy Clin Immunol. 2000;105:582-6.

Sicherer SH, Muñoz-Furlong A, Sampson HA. Prevalence of peanut and tree nut allergy in the United States determined by means of a random digit dial telephone survey: a 5-year follow-up study. J Allergy Clin Immunol. 2003;112:1203-7.

Sicherer SH, Sampson HA. Food allergy. J Allergy Clin Immunol. 
2006;117:S470-5.

Simons FE. First-aid treatment of anaphylaxis to food: focus on epinephrine. J Allergy Clin Immunol. 2004;113:837-44.

Skripak JM, Matsui EC, Mudd K, Wood RA. The natural history of IgEmediated cow's milk allergy. J Allergy Clin Immunol. 2007;120:1172-7.

Tan BM, Sher MR, Good RA, Bahna SL. Severe food allergies by skin contact. Ann Allergy Asthma Immunol. 2001;86:583-6.

Taylor SL, Hefle SL, Bindslev-Jensen C, Atkins FM, Andre C, BruijnzeelKoomen C, Burks AW, Bush RK, Ebisawa M, Eigenmann PA, Host A, Hourihane JO, Isolauri E, Hill DJ, Knulst A, Lack G, Sampson HA, MoneretVautrin DA, Rance F, Vadas PA, Yunginger JW, Zeiger RS, Salminen JW, Madsen C, Abbott P. A consensus protocol for the determination of the threshold doses for allergenic foods: how much is too much? Clin Exp Allergy. 2004;34:689-95.

Thong BY, Hourihane JO. Monitoring of lgE-mediated food allergy in childhood. Acta Paediatr. 2004;93:759-64.

Turjanmaa K, Darsow U, Niggemann B, Rancão F, Vanto T, Werfel T. EAACI/GA2LEN position paper: present status of the atopy patch test. 
Allergy. 2006;611:377-84.

Vandenplas Y, Koletzko S, Isolauri E, Hill D, Oranje AP, Brueton M, Staiano A, Dupont C. Guidelines for the diagnosis and management of cow's milk protein allergy in infants. Arch Dis Child. 2007;92:902-8.

van Odijk J, Kull I, Borres MP, Brandtzaeg P, Edberg U, Hanson LA, Høst A, Kuitunen M, Olsen SF, Skerfving S, Sundell J, Wille S. Breastfeeding and allergic disease: a multidisciplinary review of the literature (1966-2001) on the mode of early feeding in infancy and its impact on later atopic manifestations. Allergy. 2003;58:833-43.

Van Wijk F, Knippels L. Initiating mechanisms of food allergy: Oral tolerance versus allergic sensitization. Biomed Pharmacother. 2007;61:8-20.

Vieira MC, Toporovski M, Morais MB, Spolidoro JV, Fonseca MC, Araújo CT, Castro V, Osmo H. Cow's milk allergy in children: a survey on itsmain features in Brazil. JPEN J Parenter Enteral Nutr. 2005;31:1599-606.

Vlieg-Boerstra BJ, Bijleveld CM, van der Heide S, Beusekamp BJ, WoltPlompen SA, Kukler J, Brinkman J, Duiverman EJ, Dubois AE. Development and validation of challenge materials for double-blind, placebo-controlled food challenges in children. J Allergy Clin Immunol. 2004;113:341-6. 
Vlieg-Boerstra BJ, Duiverman EJ, van der Heide S, Bijleveld CM, Kukler J, Dubois AE. Should children with a history of anaphylaxis to foods undergo challenge testing? Clin Exp Allergy. 2008;38:1935-42.

Vlieg-Boerstra BJ, van der Heide S, Bijleveld CM, Kukler J, Duiverman EJ, Dubois AE. Placebo reactions in double-blind, placebo-controlled food challenges in children. Allergy. 2007;62:905-12.

Wahn U, Von Mutius E. Childhood risk factors for atopy and the importance of early intervention. J Allergy Clin Immunol. 2001;107:567-74.

Wal JM. Bovine milk allergenicity. Ann Allergy Asthma Immunol. 2004;(Suppl 3):S2-S11.

Wal JM. Cow's milk allergens. Allergy. 1998;53:1013-22.

Williams LW, Bock SA. Skin testing and food challenges in allergy and immunology practice. Clin Rev Allergy Immunol. 1999;17:323-38.

Zeiger RS. Food allergen avoidance in the prevention of food allergy in infants and children. Pediatrics. 2003;111:1662-71. 